\title{
Vehicle Codes and Standards: Overview and Gap Analysis
}

Technical Report NREL/TP-560-47336

February 2010

C. Blake, W. Buttner, and C. Rivkin

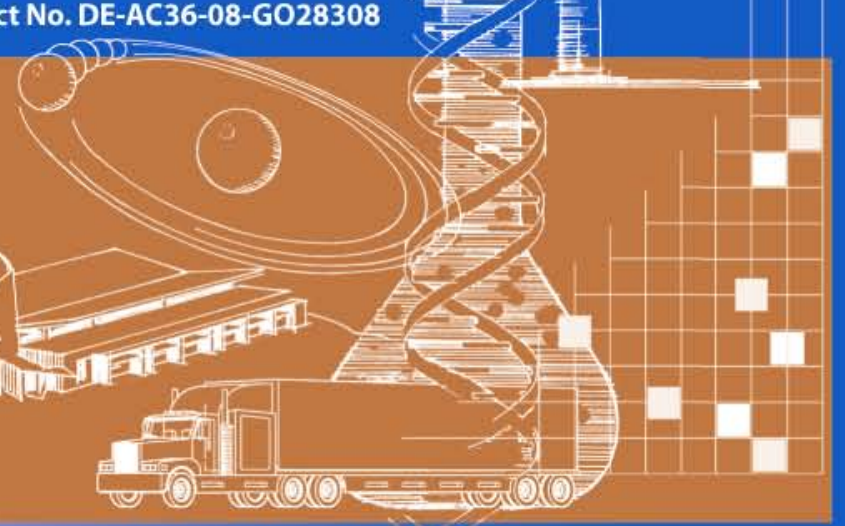




\section{Vehicle Codes and Standards: Overview and Gap Analysis}

Technical Report NREL/TP-560-47336 February 2010

\author{
C. Blake, W. Buttner, and C. Rivkin
}

Prepared under Task No. FC08.7730

National Renewable Energy Laboratory 1617 Cole Boulevard, Golden, Colorado 80401-3393 303-275-3000 • www.nrel.gov

NREL is a national laboratory of the U.S. Department of Energy Office of Energy Efficiency and Renewable Energy

Operated by the Alliance for Sustainable Energy, LLC

Contract No. DE-AC36-08-GO28308

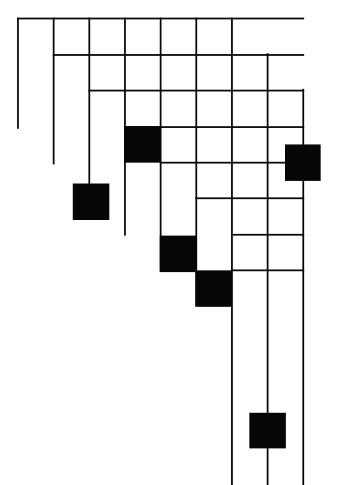




\section{NOTICE}

This report was prepared as an account of work sponsored by an agency of the United States government. Neither the United States government nor any agency thereof, nor any of their employees, makes any warranty, express or implied, or assumes any legal liability or responsibility for the accuracy, completeness, or usefulness of any information, apparatus, product, or process disclosed, or represents that its use would not infringe privately owned rights. Reference herein to any specific commercial product, process, or service by trade name, trademark, manufacturer, or otherwise does not necessarily constitute or imply its endorsement, recommendation, or favoring by the United States government or any agency thereof. The views and opinions of authors expressed herein do not necessarily state or reflect those of the United States government or any agency thereof.

Available electronically at http://www.osti.gov/bridge

Available for a processing fee to U.S. Department of Energy and its contractors, in paper, from:

U.S. Department of Energy

Office of Scientific and Technical Information

P.O. Box 62

Oak Ridge, TN 37831-0062

phone: 865.576 .8401

fax: 865.576 .5728

email: mailto:reports@adonis.osti.gov

Available for sale to the public, in paper, from:

U.S. Department of Commerce

National Technical Information Service

5285 Port Royal Road

Springfield, VA 22161

phone: 800.553.6847

fax: 703.605.6900

email: orders@ntis.fedworld.gov

online ordering: http://www.ntis.gov/ordering.htm 


\section{Executive Summary}

Codes and standards are implemented to ensure that processes and products meet uniform requirements. These requirements pertain to either safety or performance specifications. The Vehicle Codes and Standards Group at the National Renewable Energy Laboratory (NREL) conducted an analysis of the full range of codes and standards that apply to alternative vehicle fuels to determine where the gaps are located in the codes and standards and what work must be performed to fill these gaps. For this analysis, the term codes and standards gap was broadened to include regulatory or policy issues that would impede the application of a technology. Six most commonly available fuels designated by the Department of Energy (DOE) as vehicle alternative fuels are as follows:
1. Biodiesel
2. Natural Gas (NG)
3. Electricity
4. Ethanol
5. Hydrogen
6. Propane

One of the most significant findings is that vehicle codes and standards have traditionally been approached on a case-by-case basis by DOE. With the exception of Hydrogen, no DOE coordinated effort took place to address codes and standards related to all alternative fuels. As a result, occasions where one DOE-funded group did not coordinate with other DOE-funded efforts in key codes and standards issues or committees occurred. A coordinated approach to alternative fuel vehicle technologies codes and standards would result in an efficient and effective codes and standards program.

Table 1 summarizes significant key gaps in existing vehicle codes and standards identified during analysis. The table is organized by fuel type with the exception of gaps that apply to all fuels. The individual fuel sections provide additional extensive listings of codes and standards gaps. The gaps listed in this table were deemed more important by the authors or the experts interviewed by the authors.

This report was written with the input from experts in all of the vehicle alternative fuels. Table 2 identifies the various experts who provided input to this report. 
Table 1: Summary of Vehicle Codes and Standards Gaps

\begin{tabular}{|c|c|c|c|}
\hline Fuel & $\begin{array}{l}\text { Vehicle Codes and } \\
\text { Standards Gap }\end{array}$ & $\begin{array}{l}\text { Documents } \\
\text { Impacted }\end{array}$ & Gap Resolution \\
\hline BIODIESEL & $\begin{array}{l}\text { Lack of data for existing } \\
\text { codes and standards } \\
\text { applicability to biodiesel } \\
\text { storage systems }\end{array}$ & $\begin{array}{l}\text { National Fire } \\
\text { Protection } \\
\text { Association (NFPA) } \\
30 \text { and } 30 A \text { and } \\
\text { associated listing } \\
\text { documents, IFC }\end{array}$ & $\begin{array}{l}\text { Provide data for the } \\
\text { compatibility of } \\
\text { Biodiesel with listed } \\
\text { storage }\end{array}$ \\
\hline BIODIESEL & $\begin{array}{l}\text { Limited component } \\
\text { compatibility }\end{array}$ & $\begin{array}{l}\text { Multiple Society of } \\
\text { Automotive } \\
\text { Engineers (SAE) } \\
\text { documents }\end{array}$ & $\begin{array}{l}\text { Work with SAE } \\
\text { committees and } \\
\text { provide data to } \\
\text { support changes } \\
\text { allowing for more } \\
\text { component flexibility }\end{array}$ \\
\hline ELECTRICITY & $\begin{array}{l}\text { Code enforcers lack of } \\
\text { familiarity with charging } \\
\text { station requirements, } \\
\text { particularly for home } \\
\text { charging stations }\end{array}$ & $\begin{array}{l}\text { NFPA 70, Article } \\
625\end{array}$ & $\begin{array}{l}\text { Education and } \\
\text { outreach required to } \\
\text { increase familiarity } \\
\text { with the NFPA } 70 \\
\text { requirements }\end{array}$ \\
\hline ELECTRICITY & $\begin{array}{l}\text { Battery standards are } \\
\text { not complete, } \\
\text { specifically: } \\
\text { 1. SAE } 1797 \text { does not } \\
\text { address lithium lon } \\
\text { batteries } \\
\text { 2. SAE J1798 does not } \\
\text { address temperature } \\
\text { testing } \\
\text { 3. SAE } 2288 \text { does not } \\
\text { address temperature } \\
\text { variation and testing } \\
\text { 4. SAE } 2380 \text { does not } \\
\text { address battery } \\
\text { mounting and } \\
\text { vibration testing }\end{array}$ & $\begin{array}{l}\text { SAE J1797, SAE } \\
\text { J1798, SAE J 2288, } \\
\text { SAE J } 2380\end{array}$ & $\begin{array}{l}\text { The standards } \\
\text { development } \\
\text { activities need to be } \\
\text { monitored to ensure } \\
\text { that the required } \\
\text { data are available to } \\
\text { the technical } \\
\text { committees to } \\
\text { promulgate their } \\
\text { revised documents }\end{array}$ \\
\hline
\end{tabular}




\begin{tabular}{|c|c|c|c|}
\hline Fuel & $\begin{array}{l}\text { Vehicle Codes and } \\
\text { Standards Gap }\end{array}$ & $\begin{array}{l}\text { Documents } \\
\text { Impacted }\end{array}$ & Gap Resolution \\
\hline ELECTRICITY & $\begin{array}{l}\text { Communications } \\
\text { between the vehicle and } \\
\text { the grid require further } \\
\text { definition }\end{array}$ & $\begin{array}{l}2293 \text { - Updates for } \\
\text { current } \\
\text { communication } \\
\text { technology - Nat } \\
\text { Labs participation } \\
2836 \text { - Part 1, 2, } 3 \\
\text { all need updates for } \\
\text { communication } \\
\text { requirements } \\
2847 \text { - Part 1, 2, } 3 \\
\text { not complete, need } \\
\text { technical } \\
\text { requirements for } \\
\text { communications }\end{array}$ & $\begin{array}{l}\text { The standards } \\
\text { development } \\
\text { activities need to be } \\
\text { monitored to ensure } \\
\text { that the required } \\
\text { data are available to } \\
\text { the technical } \\
\text { committees to } \\
\text { promulgate their } \\
\text { revised documents }\end{array}$ \\
\hline ELECTRICITY & $\begin{array}{l}\text { Communications within } \\
\text { the grid to balance } \\
\text { vehicle charging loads }\end{array}$ & $\begin{array}{l}\text { National Institute of } \\
\text { Standards and } \\
\text { Technology (NIST) } \\
\text { standards, Institute } \\
\text { of Electrical and } \\
\text { Electronics } \\
\text { Engineers (IEEE) } \\
1547\end{array}$ & $\begin{array}{l}\text { The codes and } \\
\text { standards activities } \\
\text { require monitoring to } \\
\text { determine where } \\
\text { data are needed to } \\
\text { ensure that the } \\
\text { documents are } \\
\text { promulgated }\end{array}$ \\
\hline ETHANOL & $\begin{array}{l}\text { Component compatibility } \\
\text { with high ethanol } \\
\text { concentration mixtures }\end{array}$ & $\begin{array}{l}\text { NFPA } 30 / 30 A \text { and } \\
\text { associated listing } \\
\text { documents, SAE } \\
2835\end{array}$ & $\begin{array}{l}\text { Provide data for the } \\
\text { compatibility of } \\
\text { Ethanol with } \\
\text { traditional gasoline } \\
\text { vehicle components }\end{array}$ \\
\hline ETHANOL & $\begin{array}{l}\text { Lack of data for existing } \\
\text { codes and standards } \\
\text { applicability to Ethanol } \\
\text { storage systems }\end{array}$ & $\begin{array}{l}\text { NFPA } 30 / 30 \mathrm{~A} \text { and } \\
\text { associated listing } \\
\text { documents, IFC }\end{array}$ & $\begin{array}{l}\text { Provide data for the } \\
\text { compatibility of } \\
\text { Ethanol with listed } \\
\text { storage }\end{array}$ \\
\hline HYDROGEN & $\begin{array}{l}\text { High pressure storage, } \\
\text { handling, and use of } \\
\text { hydrogen presents } \\
\text { hazards specific to high- } \\
\text { pressure systems that } \\
\text { may not be completely } \\
\text { addressed }\end{array}$ & $\begin{array}{l}\text { NFPA 2, NFPA 52, } \\
\text { NFPA 55 } \\
\text { Compressed Gas } \\
\text { Association (CGA) H } \\
\text { series of documents, } \\
\text { International Fire } \\
\text { Code (IFC) }\end{array}$ & $\begin{array}{l}\text { Evaluated codes } \\
\text { and standards that } \\
\text { address high } \\
\text { pressures to } \\
\text { determine if } \\
\text { requirements are } \\
\text { adequate }\end{array}$ \\
\hline
\end{tabular}




\begin{tabular}{|c|c|c|c|}
\hline Fuel & $\begin{array}{l}\text { Vehicle Codes and } \\
\text { Standards Gap }\end{array}$ & $\begin{array}{l}\text { Documents } \\
\text { Impacted }\end{array}$ & Gap Resolution \\
\hline HYDROGEN & $\begin{array}{l}\text { Incomplete } \\
\text { requirements for } \\
\text { sensing technologies }\end{array}$ & $\begin{array}{l}\text { NFPA 2, NFPA 52, } \\
\text { NFPA 55, IFC }\end{array}$ & $\begin{array}{l}\text { Support the use of } \\
\text { sensing } \\
\text { technologies that } \\
\text { replace odorants } \\
\text { through evaluating } \\
\text { sensing } \\
\text { technologies and } \\
\text { supporting code and } \\
\text { standards } \\
\text { development work in } \\
\text { sensing } \\
\text { technologies }\end{array}$ \\
\hline HYDROGEN & $\begin{array}{l}\text { Off-road vehicle storage } \\
\text { tank requirements are } \\
\text { incomplete }\end{array}$ & $\begin{array}{l}\text { Codes and } \\
\text { Standards of } \\
\text { America (CSA) } \\
\text { Heavy Goods } \\
\text { Vehicle (HGV) 2, } \\
\text { SAE J2601, } \\
\text { Underwriters' } \\
\text { Laboratories, Inc. } \\
\text { (UL) } 2267\end{array}$ & $\begin{array}{l}\text { Support standards } \\
\text { development work } \\
\text { with direct } \\
\text { committee } \\
\text { involvement and } \\
\text { data support }\end{array}$ \\
\hline HYDROGEN & $\begin{array}{l}\text { Potentially incomplete } \\
\text { requirements for indoor } \\
\text { hydrogen fueling }\end{array}$ & NFPA 52, IFC & $\begin{array}{l}\text { Evaluate indoor } \\
\text { release } \\
\text { characteristics and } \\
\text { accident scenarios } \\
\text { for potential } \\
\text { application to code } \\
\text { development }\end{array}$ \\
\hline NG & $\begin{array}{l}\text { Outreach products for } \\
\text { installation technicians } \\
\text { and conversion shops }\end{array}$ & Multiple & $\begin{array}{l}\text { Produce outreach } \\
\text { products for } \\
\text { consumers, } \\
\text { installation shops, } \\
\text { and technicians }\end{array}$ \\
\hline NG & $\begin{array}{l}\text { Component } \\
\text { standardization }\end{array}$ & Multiple documents & $\begin{array}{l}\text { Support } \\
\text { development of } \\
\text { component } \\
\text { standards }\end{array}$ \\
\hline
\end{tabular}




\begin{tabular}{|c|c|c|c|}
\hline Fuel & $\begin{array}{l}\text { Vehicle Codes and } \\
\text { Standards Gap }\end{array}$ & $\begin{array}{l}\text { Documents } \\
\text { Impacted }\end{array}$ & Gap Resolution \\
\hline PROPANE & Conversion components & $\begin{array}{l}\text { NFPA } 58 \text { or UL } \\
\text { listing document }\end{array}$ & $\begin{array}{l}\text { Provide data to } \\
\text { ensure component } \\
\text { listings are valid }\end{array}$ \\
\hline PROPANE & $\begin{array}{l}\text { Compositional and fuel } \\
\text { quality concerns }\end{array}$ & $\begin{array}{l}\text { American Society for } \\
\text { Testing and } \\
\text { Materials (ASTM) D } \\
\text { 1835-97 }\end{array}$ & $\begin{array}{l}\text { Provide data from } \\
\text { the analysis of fuel } \\
\text { quality and impact } \\
\text { on vehicle systems }\end{array}$ \\
\hline ALL FUELS & $\begin{array}{l}\text { Focus research } \\
\text { activities on system } \\
\text { engineering to reduce } \\
\text { the probability of a } \\
\text { release or incident } \\
\text { rather than evaluating } \\
\text { the potential impacts of } \\
\text { a release or incident }\end{array}$ & Multiple documents & $\begin{array}{l}\text { Conduct more } \\
\text { research on system } \\
\text { safety engineering } \\
\text { rather than modeling } \\
\text { of incidents }\end{array}$ \\
\hline ALL FUELS & $\begin{array}{l}\text { Lack of familiarity with } \\
\text { codes and standards } \\
\text { among project } \\
\text { developers and AHJs }\end{array}$ & Multiple documents & $\begin{array}{l}\text { Continue to conduct } \\
\text { regional training } \\
\text { workshops and } \\
\text { develop specialized } \\
\text { web education } \\
\text { products }\end{array}$ \\
\hline ALL FUELS & $\begin{array}{l}\text { Develop operational } \\
\text { safety requirements for } \\
\text { fueling operations as } \\
\text { data are accrued } \\
\text { through learning } \\
\text { demonstrations }\end{array}$ & Multiple documents & $\begin{array}{l}\text { Analyze fueling } \\
\text { data, particularly for } \\
\text { new fueling } \\
\text { technologies at } \\
\text { facilities with } \\
\text { multiple fuels, to } \\
\text { determine whether } \\
\text { operations safety } \\
\text { can be increased }\end{array}$ \\
\hline
\end{tabular}


Table 2: Codes and Standards Experts

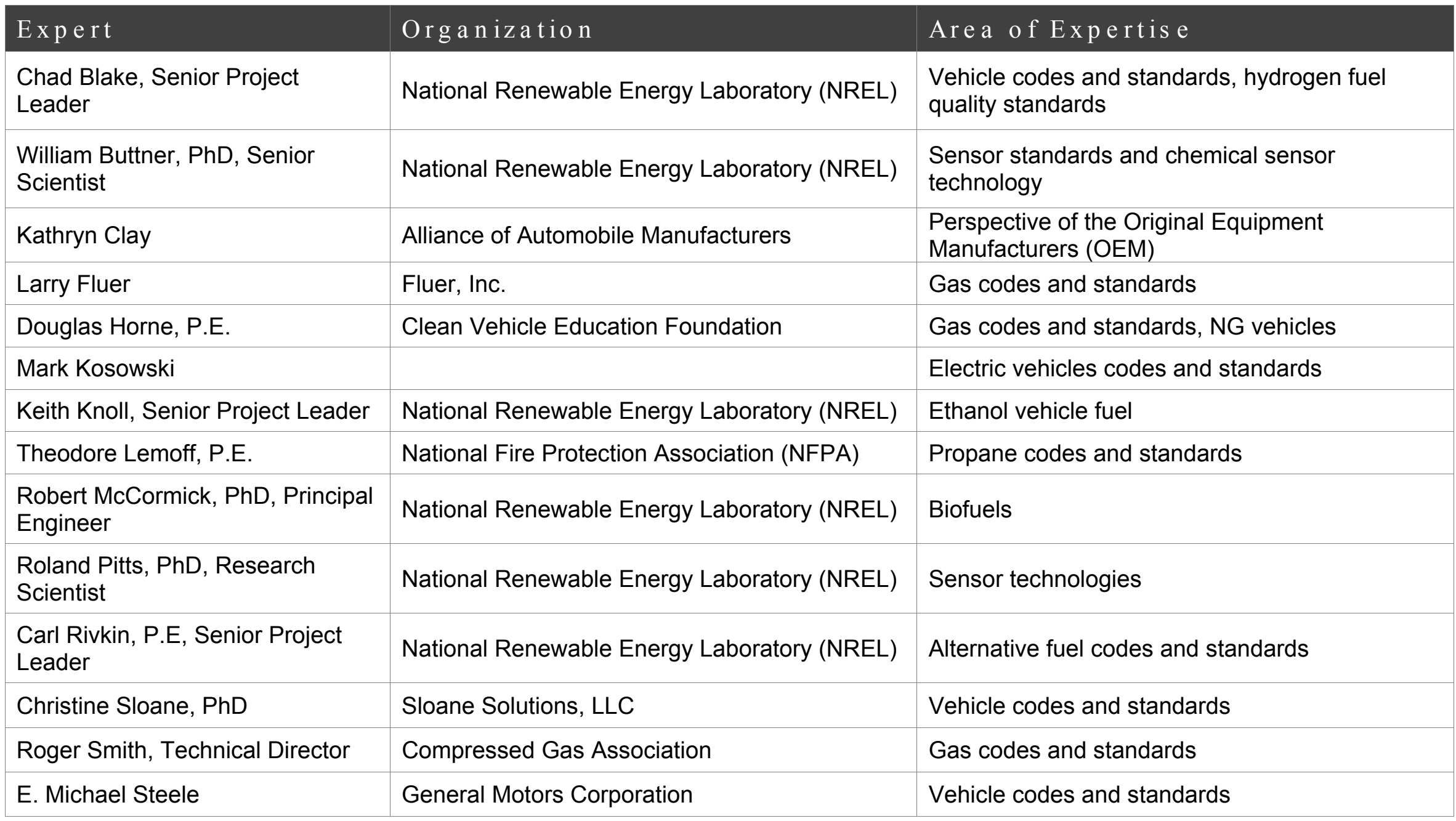




\section{$\underline{\text { Table of Contents }}$}

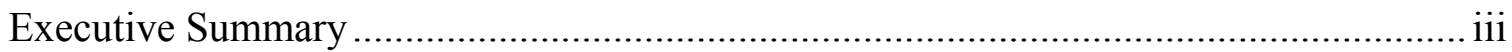

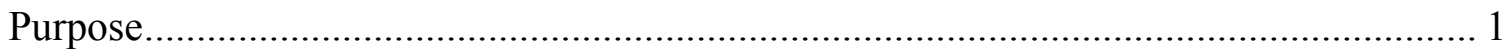

Vehicle Technologies Codes and Standards Project...................................................... 4

The DOE Vehicles Technologies Program............................................................... 5

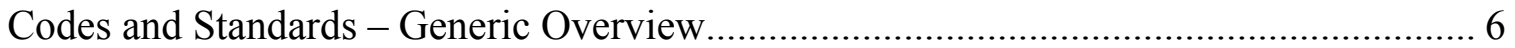

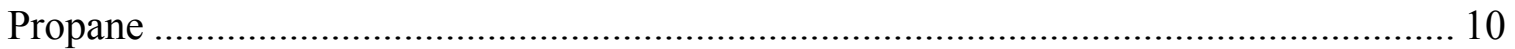

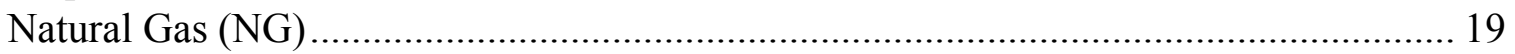

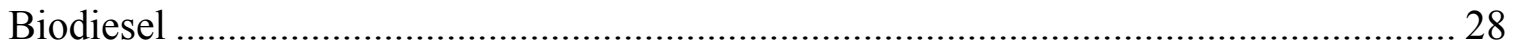

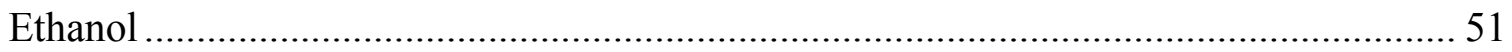

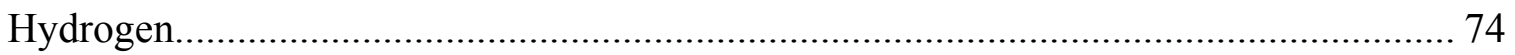

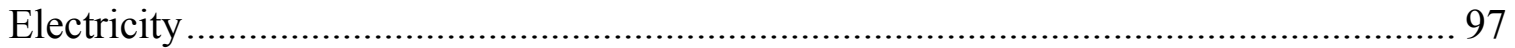

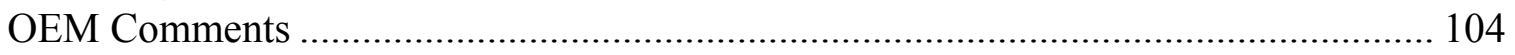

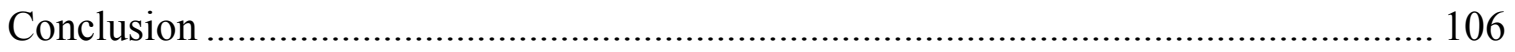

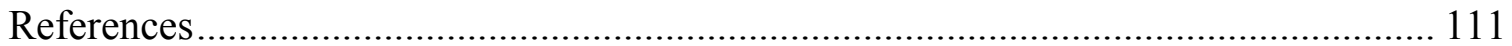

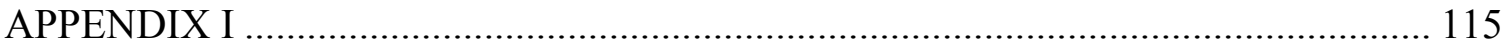

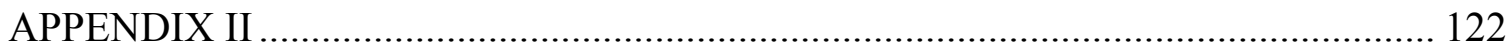

\section{List of Figures}

Figure 1: The NREL Vehicle Codes and Standards Project............................................. 7

Figure 2: The Codes and Standards Development Process .............................................. 8

Figure 3: Number of Propane vehicles in use in the United States (1993-2002) ............ 10

Figure 4: Annual production levels in the U.S. of Biodiesel (2000 to 2008) .................. 28

\section{List of Tables}

Table 1: Summary of Vehicle Codes and Standards Gaps ............................................. iv

Table 2: Codes and Standards Experts....................................................................... viii

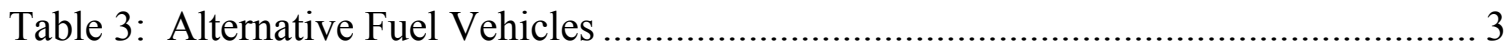

Table 4: Code citations in NFPA 58 (Propane) …………........................................... 11

Table 5: Codes and Standards Gaps for Propane ......................................................... 17

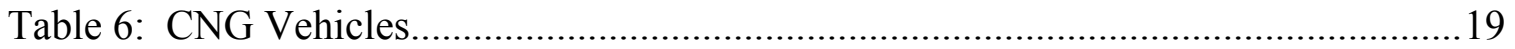

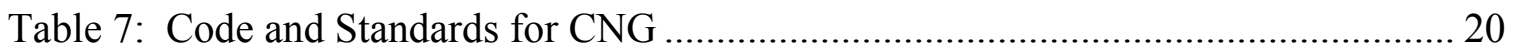

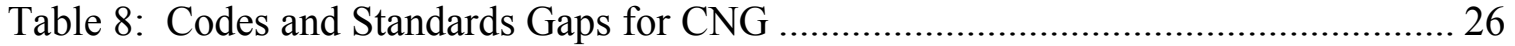

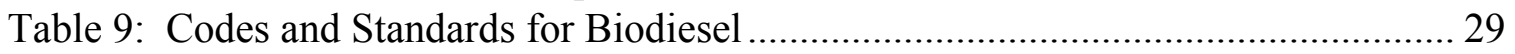

Table 10: Codes and Standards Gaps for Biodiesel....................................................... 49

Table 11: Codes and Standards for Ethanol Fuel.......................................................... 51

Table 12: Codes and Standards Gaps for Ethanol ………........................................ 72

Table 13: Codes and Standards for Hydrogen ............................................................. 75

Table 14: Codes and Standards Gaps for Hydrogen ................................................... 93

Table 15: Gaps in Electricity Codes and Standards...................................................... 101

Table 16: Summary of Vehicle Codes and Standards Gaps ......................................... 106 


\section{Acronyms}

AHJ

ANSI

API

ASCE

ASME

ASTM

CAFCP

CGA

CNG

CSA

DOE

DOT

EPA

EV

FFV

GTR

HGV

IBC

ICC

IEEE

IFC

IMC

ISO

LNG

MAQ

NACE

NEC

NFPA

NG

NGV

NIOSH

NIST

NREL

OEM

PERC

ppm

SAE

SDO

SMR

STI

UL

ULC

UST

TIR
Authorities having Jurisdiction

American National Standards Institute

American Petroleum Institute

American Society of Civil Engineers

American Society of Mechanical Engineers

American Society for Testing and Materials

California Fuel Cell Partnership

Compressed Gas Association

Compressed Natural Gas

Codes and Standards of America

U.S. Department of Energy

U.S. Department of Transportation

U.S. Environmental Protection Agency

Electrical Vehicle

Flex-Fuel Vehicle

Global Technical Regulations

heavy goods vehicle

International Building Code

International Code Council

Institute of Electrical and Electronics Engineers

International Fire Code

International Mechanical Code

International Organization for Standardization

Liquefied Natural Gas

Maximum Allowable Quantities

National Association of Corrosion Engineers

National Electrical Code

National Fire Protection Association

Natural Gas

Natural Gas Vehicle

National Institute for Occupational Safety and Health

National Institute of Standards and Technology

National Renewable Energy Laboratory

Original Equipment Manufacturer

Propane Education Research Council

parts per million

Society of Automotive Engineers

Standards Development Organizations

Steam Methane Reformation

Safety Technology International

Underwriters' Laboratories, Inc.

Underwriters' Laboratories of Canada

Underground Storage Tanks

Technical Information Report 


\section{Purpose}

The purpose of this report is to identify gaps in vehicle codes and standards and to recommend actions that provide a means to fill these gaps. The focus of this gap analysis is on the alternative fuels identified by the U.S. Department of Energy (DOE) [1]. The existence of these gaps represents barriers to the implementation of alternative fuels. This analysis also identifies specific activity that leads to the elimination of the codes and standards gaps. These recommendations will help define codes and standards development work and priorities. Previously, such barrier analyses were addressed on a project-by-project basis; however, a comprehensive codes and standards gap analysis for the various alternative fuels has not been approached. This report presents the first comprehensive summary of the codes and standard gaps for all of the alternative fuels identified by DOE for vehicle transportation.

Codes and standards facilitate the development and implementation of new technologies. This is especially true in cases where commercial success is predicated upon contributions from multiple industries, such as alternative fuels for transportation. Vehicles must be available that are compatible with the fuel. At the same time, it is also required that fuel be available for the vehicle, thereby requiring transit, storage, and transfer infrastructure. To ensure national security for the United States and to alleviate the dependence on imported fossil fuels, the DOE Vehicle Technologies Program supports the use of alternative fuels for vehicles [1]. Six of these fuels are as follows:

1. Biodiesel

2. Natural Gas (NG)

3. Electricity

4. Ethanol

5. Hydrogen

6. Propane

Several other fuels are available, many of which may have other benefits such as reduced emissions or increased energy security. Each of the six identified alternative fuels for vehicle applications are at different maturity levels. Several fuels have been successfully used for many years, while others are more recent developments. As a result, the codes and standards for each are at different stages of development. Codes and standards that address the vehicle, dispensing systems, storage, as well as the infrastructure to support production and transportation exist for all six of these fuels. However, the codes and standards development for all six fuel types is not complete and critical gaps are identified, as discussed below. Also, the existing production capacity and infrastructure varies significantly among the six fuels. Nevertheless, the use of alternative fuels is growing and the number of vehicles that operate on such fuel has dramatically increased in the past decade. Some of the alternative fuels, such as Propane and CNG, already have an extensive deployment history. Accordingly, well-established codes and standards exist for these two fuels, although as discussed below, gaps still exist in the relevant standards for both Propane and CNG. Other fuels, such as Ethanol and Biodiesel may be viewed as extensions of the conventional fueling systems, but production capacity and material compatibility concerns exist. Thus, some code and standard development is still required. 
A third group of alternative fuels, Hydrogen and Electricity, are major new technological developments for use as vehicle fuels. New power systems (electric motors) will replace the internal combustion engine. Unique infrastructure impacts will be encountered, including production capacity and impact on existing demands, safety, as well as achieving appropriate vehicle performance in a consumer market. Thus, the successful implementation of these two fuels as viable alternative fuels requires the majority of the development of new codes and standards relative to the other identified alternative fuel types.

With the addition of Hydrogen as an alternative fuel, a dedicated group established at National Renewable Energy Laboratory (NREL) specifically addresses codes and standards issues as they relate to hydrogen vehicles. The mission of this group is to identify and eliminate codes and standards barriers before such gaps prevent the implementation of Hydrogen as a vehicle fuel. A comprehensive approach has been applied, and the NREL codes and standards group is actively involved in issues related to hydrogen safety, fuel quality, education and outreach programs, as well as production, transit, and storage infrastructure. The activity's success clearly demonstrates that the application of this approach to the other alternative fuels will facilitate effective implementation of related codes and standards.

Although the vast majority of the existing vehicles use conventional internal combustion engines (ICE) powered by petroleum, the use of alternative fuels for vehicles is well established. Table 3 (table 10.4 in the 2007 Energy Information Office annual review) [2] provides the number of alternative fuel vehicles in the United States. The table provides information on five of the six fuels. Biodiesel does not appear in the table as an independent fuel type. Rather, in this report, biodiesel is considered a class of diesel. Ethanol appears as both Ethanol 85 percent and Ethanol 95 percent. Ethanol (E85), Propane (Liquefied Petroleum Gas in the table), and CNG account for 578,076 of the 634,562 alternative fuel vehicles in 2006, or approximately 91 percent of the total. In 2006, there were 159 hydrogen vehicles or approximately 0.025 percent. Electric vehicles make up about 8.4 percent of the alternative fuel vehicles. These numbers reflect the maturity of the Propane and CNG technologies and show that current gasoline ICEs can run on blends of gasoline and ethanol without major modifications.

The number of vehicles powered by alternative fuels is growing. To facilitate the development of the emerging alternative fuel markets, the Vehicle Codes and Standards Group at NREL initiated a study to identify specific gaps in the code and standard structure for each of the six identified alternative fuels. This codes and standards analysis was broadened to include regulatory or policy issues that impede application of a technology. This gap analysis involved a comprehensive review of the existing codes and standards currently applied to each fuel type. To ensure a thorough analysis was performed; experts in the transportation industry with extensive hands-on experience in each alternative fuel area were consulted. These experts provided unique insights into the status of the identified fuels. The expert discussions were incorporated into the following analysis. See Appendix I for brief expert biographies. 
Table 3: Alternative Fuel Vehicles (obtained from Table 10.4 in [2])

\begin{tabular}{|c|c|c|c|c|c|c|c|c|c|c|c|c|c|c|c|c|}
\hline \multirow[b]{3}{*}{ Year } & \multicolumn{16}{|c|}{ Alternative and Replacement Fuels ${ }^{1}$} \\
\hline & \multirow{2}{*}{$\begin{array}{c}\text { Liquefied } \\
\text { Petroleum } \\
\text { Gases }\end{array}$} & \multirow{2}{*}{$\begin{array}{c}\text { Compressed } \\
\text { Natural } \\
\text { Gas }\end{array}$} & \multirow{2}{*}{$\begin{array}{l}\text { Liquefied } \\
\text { Natural } \\
\text { Gas }\end{array}$} & \multirow{2}{*}{$\begin{array}{l}\text { Methanol, } \\
85 \text { Percent } \\
\text { (M85) }^{3}\end{array}$} & \multirow{2}{*}{$\begin{array}{c}\text { Methanol, } \\
\text { Neat } \\
(\text { M100) }\end{array}$} & \multirow{2}{*}{$\begin{array}{c}\text { Ethanol, } \\
85 \text { Percent } \\
\text { (E85) } 3.5\end{array}$} & \multirow{2}{*}{$\begin{array}{l}\text { Ethanol, } \\
\text { 95 Percent } \\
\text { (E95) }^{3}\end{array}$} & \multirow[b]{2}{*}{$\begin{array}{c}\text { Elec- } \\
\text { tricity }\end{array}$} & \multirow[b]{2}{*}{$\begin{array}{c}\text { Hydro- } \\
\text { gen }\end{array}$} & \multirow[b]{2}{*}{$\begin{array}{l}\text { Other } \\
\text { Fuels }^{7}\end{array}$} & \multirow[b]{2}{*}{ Total } & \multicolumn{3}{|c|}{ Oxygenates 2} & \multirow[b]{2}{*}{$\begin{array}{c}\text { Bio- } \\
\text { diesel }\end{array}$} & \multirow[b]{2}{*}{ Total } \\
\hline & & & & & & & & & & & & \begin{tabular}{|c|} 
Methyl Tertiary \\
Butyl Ether
\end{tabular} & $\begin{array}{l}\text { Ethanol in } \\
\text { Gasohol }{ }^{9}\end{array}$ & Total & & \\
\hline & \multicolumn{16}{|c|}{ Alternative-Fueled Vehicles in Use ${ }^{11}$ (number) } \\
\hline 1992 & NA & 23,191 & 90 & 4,850 & 404 & 172 & 38 & 1,607 & NA & NA & NA & NA & NA & NA & NA & NA \\
\hline 1993 & NA & 32,714 & 299 & 10,263 & 414 & 441 & 27 & 1,690 & NA & NA & NA & NA & NA & NA & NA & NA \\
\hline 1994 & NA & 41,227 & 484 & 15,484 & 415 & 605 & 33 & 2,224 & NA & NA & NA & NA & NA & NA & NA & NA \\
\hline 1995 & 172,806 & 50,218 & 603 & 18,319 & 386 & 1,527 & 136 & 2,860 & 0 & 0 & 246,855 & NA & NA & NA & NA & NA \\
\hline 1996 & 175,585 & 60,144 & 663 & 20,265 & 172 & 4.536 & 361 & 3,280 & 0 & 0 & 265,006 & NA & NA & NA & NA & NA \\
\hline 1997 & 175,679 & 68.571 & 813 & 21,040 & 172 & 9.130 & 347 & 4,453 & 0 & 0 & 280.205 & NA & NA & NA & NA & NA \\
\hline 1998 & 177,183 & 78,782 & 1,172 & 19,648 & 200 & 12,788 & 14 & 5,243 & 0 & 0 & 295,030 & NA & NA & NA & NA & NA \\
\hline 1999 & 178,610 & 91,267 & 1,681 & 18,964 & 198 & 24,604 & 14 & 6,964 & 0 & 0 & 322,302 & NA & NA & NA & NA & NA \\
\hline 2000 & 181,994 & 100,750 & 2,090 & 10,426 & 0 & 87,570 & 4 & 11,830 & 0 & 0 & 394,684 & NA & NA & NA & NA & NA \\
\hline 2001 & 185,053 & 111,851 & 2,576 & 7,827 & 0 & 100,303 & 0 & 17,847 & 0 & 0 & 425,457 & NA & NA & NA & NA & NA \\
\hline 2002 & 187,680 & 120.839 & 2,708 & 5,873 & 0 & 120,851 & 0 & 33,047 & 0 & 0 & 471,098 & NA & NA & NA & NA & NA \\
\hline 2003 & 190,369 & 114,406 & 2,640 & 0 & 0 & 179,090 & 0 & 47,485 & 9 & 0 & 533,999 & NA & NA & NA & NA & NA \\
\hline 2004 & 182,864 & 118,532 & 2,717 & 0 & 0 & 211,800 & 0 & 49,536 & 43 & 0 & 565,492 & NA & NA & NA & NA & NA \\
\hline 2005 & 173,795 & 117,699 & 2,748 & 0 & 0 & 246,363 & 0 & 51,398 & 119 & 3 & 592,125 & NA & NA & NA & NA & NA \\
\hline \multirow[t]{2}{*}{$2006^{P}$} & 164,846 & 116,131 & 2,798 & 0 & 0 & 297,099 & 0 & 53,526 & 159 & 3 & 634,562 & NA & NA & NA & NA & NA \\
\hline & \multicolumn{16}{|c|}{ Fuel Consumption ${ }^{12}$ (thousand gasoline-equivalent gallons) } \\
\hline 1992 & NA & 17,159 & 598 & 1,121 & 2,672 & 22 & 87 & 359 & NA & NA & NA & $1,175,964$ & 719,408 & $1,895,372$ & NA & NA \\
\hline 1993 & NA & 22,035 & 1,944 & 1,671 & 3,321 & 49 & 82 & 288 & NA & NA & NA & $2,070,897$ & 779,958 & $2,850,854$ & NA & NA \\
\hline 1994 & NA & 24,643 & 2,398 & 2,455 & 3,347 & 82 & 144 & 430 & NA & NA & NA & $2,020,455$ & 868,113 & 2888,569 & NA & NA \\
\hline 1995 & 233,178 & 35,865 & 2,821 & 2,122 & 2,255 & 195 & 1,021 & 663 & 0 & 0 & 278,121 & $2,693,407$ & 934,615 & $3,628,022$ & NA & $3,906,142$ \\
\hline 1996 & 239,648 & 47,861 & 3,320 & 1,862 & 364 & 712 & 2,770 & 773 & 0 & 0 & 297,310 & $2,751,955$ & 677,537 & $3,429,492$ & NA & $3,726,802$ \\
\hline 1997 & 238,845 & 66,495 & 3,798 & 1,630 & 364 & 1,314 & 1,166 & 1,010 & 0 & 0 & 314,621 & $3,106,745$ & 852,514 & $3,959,260$ & NA & $4,273,880$ \\
\hline 1998 & 241,881 & 73,859 & 5,463 & 1,271 & 471 & 1,772 & 61 & 1,202 & 0 & 0 & 325,980 & $2,905,781$ & 912,858 & $3,818,639$ & NA & $4,144,620$ \\
\hline 1999 & 210,247 & 81,211 & 5,859 & 1,126 & 469 & 4,019 & 64 & 1,524 & 0 & 0 & 304,618 & $3,405,390$ & 975,255 & $4,380,645$ & NA & $4,685,263$ \\
\hline 2000 & 213,012 & 88,478 & 7,423 & 614 & 0 & 12,388 & 13 & 3,058 & 0 & 0 & 324,986 & $3,298,803$ & $1,114,313$ & $4,413,116$ & 6,828 & $4,744,930$ \\
\hline 2001 & 216,319 & 106,584 & 9,122 & 461 & 0 & 15,007 & 0 & 4,066 & 0 & 0 & 351,558 & $3,354,949$ & $1,173,323$ & $4,528,272$ & 7,089 & $4,886,919$ \\
\hline 2002 & 223,600 & 123,081 & 9,593 & 354 & 0 & 18.250 & 0 & 7,274 & 0 & 0 & 382,152 & $3,122,859$ & $1,450,721$ & 4.573 .580 & 16.948 & $4,972,680$ \\
\hline 2003 & 224,697 & 133,222 & 13,503 & 0 & 0 & 26,376 & 0 & 5,141 & 2 & 0 & 402,941 & $2,368,400$ & $1,919,572$ & $4,287,972$ & ค18.220 & $R_{4,709,133}$ \\
\hline 2004 & 211,883 & 158,903 & 20,888 & 0 & 0 & 31,581 & 0 & 5,269 & 8 & 0 & 428,532 & $1,877,300$ & $2,414,167$ & $4,291,467$ & $\mathrm{~A}_{28,244}$ & $R 4,748,243$ \\
\hline 2005 & 188,171 & 166,878 & 22,409 & 0 & 0 & 38,074 & 0 & 5,219 & 25 & 2 & 420,778 & $1,654,500$ & $2,756,663$ & $4,411,163$ & ค91,649 & $R_{4}, 923,590$ \\
\hline $2006^{P}$ & 173,130 & 172,011 & 23,474 & 0 & 0 & 44,041 & 0 & 5,104 & 41 & 2 & 417,803 & 435,000 & $3,729,168$ & $4,164,168$ & 260,606 & $4,842,577$ \\
\hline
\end{tabular}

1 See "Alternative Fuel" and "Replacement Fuel" in Glassary.

2 See "Oxygenates" in Glossary.

3 Remaining portion is motor gasoline. Consumption data include the motor gasoline portion of the fuel.

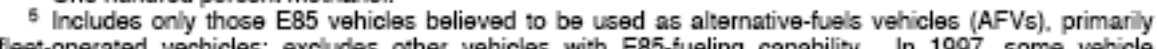
fleet-operated vechicles; exciudes other vehicles with E85-fueling capability. In 1997, some vehicle Energy Intormation Administration (EIA) estimntes that the number of EB5 vehicles that are capable of Energy in 585 , Adtor gasoline (E both, is about 6 million. Many of these AFVs are sold and used as traditional gasoline-powered vehicles.

E Excludes gasoline-electric hybrids.

7 May include P-Series fuel or any other fuel designated by the Secretary of Energy as an aternative fuel in acordance with the Energy Policy Act of 1995.

${ }^{8}$ In addition to methyl tertiary butyl ether (MTBE), includes a very small amount of other ethers, primarily tertiary amyl methyl ether (TAME) and ethyl tertiary butyl ether (ETBE).

9 Data do not include the motor gasoline portion of the fuel.

10 "Biodiesel" may be used as a diesel fuel substitute or diesel fuel additive or extender. See "Biodiesel"

in Glossary. calendar year; data do not include concept and demonstration vehicles that are not ready for delivery to end users. See "Alternative-Fueled Vehicle" in Glossary.

${ }^{12}$ Fuel consumption quantities are expressed in a common base unit of gasoline-equivalent gallons to allow companisons of different fuel types. Gasoline-equivalent gallons do not represent gasoline by the gross heat content of gasoline (using an approximate heat content of 122,619 Btu per gallon) and multiplying the result by the replacement fuel consumption value. Se日 'Heat Content' in Glossary.

R=Revised. P=Preliminary. NA=Not available.

Note: Totals may not $\theta$ qual sum of components due to independent rounding.

Web Page: For related information, see htpp//www eia doe govifuelrenewable htm.

Sources: - 1992-1994-Science Appications International Corporation, "Alternative Transportation Fuels and Vehicles Data Development," unpubished final report prepared for the EIA, (McLean, VA. July 1996), and U.S. Department of Energy. Office of Energy Efficiency and Renewable Energy. Data were revised by using gross instead of net heat contents. For a table of gross and net heat contents, se日 EIA, Aliternatives to Traditional Transportation Fuels: An Overview (June 1994), Table 22. • 1995-2002-EIA 'Alternatives to Traditional Transportation Fuels 2003 Estimated Data' (February 2004). Tables 1 and 10. Data were revised by using gross instead of net heat contents. - 2003 forward-ElA, "Aternatives to Traditional Transportation Fuels 2006" (May 2008), Tables V1 and C1. 


\section{Vehicle Technologies Codes and Standards Project}

NREL's Vehicle Codes and Standards Group applied a comprehensive approach to addressing code and standards gaps for the hydrogen vehicle program. Codes and standards issues as they related to hydrogen safety, fuel quality, education and outreach programs, as well as production, transit, and storage infrastructure were addressed. The success of this activity clearly demonstrates that this approach would facilitate implementation of the other alternative fuels. Accordingly, NREL's Vehicle Codes and Standards Group addresses all vehicle codes and standards. The approach used for hydrogen technologies, which included National Template for Codes and Standards, Research, Training and Outreach, and Codes and Standards Development, will be applied as needed to all vehicle codes and standards. Figure 1 illustrates the outline for the proposed comprehensive Vehicle Code and Standard Program.

\section{National Templates}

National templates for specific vehicle/fuel types have been developed for each of the alternative fuels. The templates provide an overview of the codes and standards associated with the vehicle, dispensing, storage, and infrastructure for each fuel type. The codes and standards referenced in each section are intended to provide a comprehensive listing of codes and standards that pertain to the specific fuel type. Appendix II lists the codes and standards for electricity.

\section{Research}

Often, sufficient data does not exist to allow for the defensible development of an enforceable standard. When the need for technical information for a code or standard is identified, a research program is initiated designed to provide the necessary data. The research is performed within the National Laboratory system, directly or through managed subcontracts, and the result is presented directly to the technical committee responsible for producing or revising a code or standard.

\section{Training and Outreach}

The Hydrogen Codes and Standards Group has an active Training and Outreach Program, providing multi-media and on-site training opportunities for code officials and other stakeholders. Training opportunities for hydrogen fuel are available through online resources, printed media, fact sheets, and on-site training workshops. Online resources include case studies of various facilities (e.g., cell towers and fueling stations), searchable databases of relevant codes organized by topic and code organization, and networking opportunities with personnel experienced in the hydrogen permitting process. Special topics are also included online, such as the "Introduction to Hydrogen for Code Officials" short course [3]. Complementing the online resources are live training workshops and presentations to various code officials. Special emphasis is on the training workshop for permitting officials, of which over 10 were held in two years [4]. The NREL Training and Outreach Program also provides Third Party Reviews for key programs (e.g., fork lift operations). Printed media includes handouts at the workshops and hydrogen fact sheets. The success of the Hydrogen Training and Outreach Program ensures that comparable programs for the alternative fuels are highly beneficial. 


\section{Vehicle Technologies Codes and Standards Development Process}

Code and standard development is occurring within the domestic market and in the international arena. Typically, code and standards are written through a consensus process by a committee comprised of interested parties and stakeholders. To ensure a balanced representation among the stakeholders during the development process, the committee is comprised of representatives from industry, end-users, and regulatory agencies. NREL is represented on several codes and standards technical committees as well as actively monitoring activities of several committees. Using information from these technical committee activities, NREL determines where research or data are needed to help develop new codes and standards requirements, and also ensures harmonization between domestic and international standards. NREL conducts research at NREL or coordinates this research so that it is conducted at other DOE laboratories or at independent laboratories under the auspices of DOE to produce the required information. NREL then presents this information directly to the codes and standards technical committees for use in the document development. By working directly with the codes and standards development committees, NREL ensures that the information needed for new codes and standards requirements is presented directly to the committee and that committee members have an opportunity to discuss and, therefore, clearly understand the information. In addition, NREL's participation on the code and standard committees ensures harmonization between standards.

The process of working directly with the codes and standards technical committees has been effective. Several projects progressed as a result of this direct participation in the codes and standards development process, including the following:

1. National Fire Protection Association (NFPA) 2 Hydrogen Technologies Codes,

2. International Organization for Standardization (ISO) 14687 Hydrogen FuelProduct Specification-Part 2: Proton exchange membrane (PEM) fuel cell applications for road vehicles,

3. Society of Automotive Engineers (SAE) J2579 Fuel Systems in Fuel Cells and other Hydrogen Vehicles, and

4. ISO Draft International Standard (DIS) 26142 Hydrogen Detection Apparatus.

\section{The DOE Vehicles Technologies Program}

One of the main objectives of the DOE Vehicle Technologies Program is to facilitate the reduction of petroleum usage in personal transportation and other commercial vehicular activity (e.g., forklifts, commercial transportation, shipping). This objective is achieved in several ways including the following:

1. Implement alternative fuel vehicles that consume less oil,

2. Develop more efficient driving behavior, and

3. Develop technologies that enable cars and trucks to become highly efficient

Items 2 and 3 above reflect behaviors and attitudes of the American public and can be addressed through training and outreach programs. Dramatic increases in fuel prices, 
such as those seen in the summer of 2008, can also facilitate such changes in behavior. Item 1 reflects technological alternatives. The DOE Vehicle Technologies Program has activities in all of these areas. The activity of NREL's Vehicle Codes and Standards Task Group crosscuts all of these areas.

\section{Codes and Standards - Generic Overview}

Codes and standards are developed to ensure that processes and products meet uniform requirements. Codes and standards guide the implementation of energy technology by providing an accessible framework that sets unified engineering and design specifications. Performance specifications, component compatibility, and safety are all addressed by codes and standards. Although often interchangeable, the terms code and standard have distinct meanings and implications. Both should be written in legally enforceable language. However, a code dictates that a requirement must be met and is often implemented and enforced by Authorities having Jurisdiction (AHJs). A standard defines how to fulfill the requirement dictated by the code. For example, a building code might require a certain type of building to use sprinkler protection. A sprinkler standard, which could be referenced within the code, then specifies the requirements for building sprinkler systems. The standard, on its own, does not require anything; it merely defines metrics within the context of the standard itself. For enforceability, the standard is incorporated into a code or regulation that mandates compliance to the standard.

Codes, and by extension standards cited within codes, are legally enforceable documents when a jurisdiction adopts them either by reference or direct incorporation into the jurisdiction's regulations. Standards, referenced in the code, then become legally enforceable documents when the code is adopted. Also many standards are complied with on a widespread basis and become an industry norm, although they are not referenced in an adopted code. This is particularly true for vehicle standards that typically have different enforcement processes than codes and standards that apply to the built environment. Codes and standards for the built environment are typically enforced at the local level by the town or county building and fire department, the typical AHJ for local governments. Vehicle codes and standards are typically enforced at the federal or state levels, which tend to have greater self-enforcement than the built environment codes and standards.

Codes and standards in the United States are, for the most part, promulgated under a system of rules established by the American National Standards Institute (ANSI) [5]. Several Standards Development Organizations (SDOs) develop codes and standards according to the ANSI rules for document development and maintenance. Figure 2 illustrates the NREL Codes and Standards development protocol, which is consistent with the procedure mandated by ANSI. 


\section{Vehicle Technologies Codes and Standards Project}

\section{National Template}

Develop and manage a

National Template of Vehicle

Codes and Standards for each

alternative fuel.
Research Laboratory

Perform and coordinate research to support the development of vehicle codes and standards.

\section{Training and Outreach}

Create web training and information products for vehicle codes and standards. Perform on site training and regional workshops directed at project developers, code officials, and interested parties.

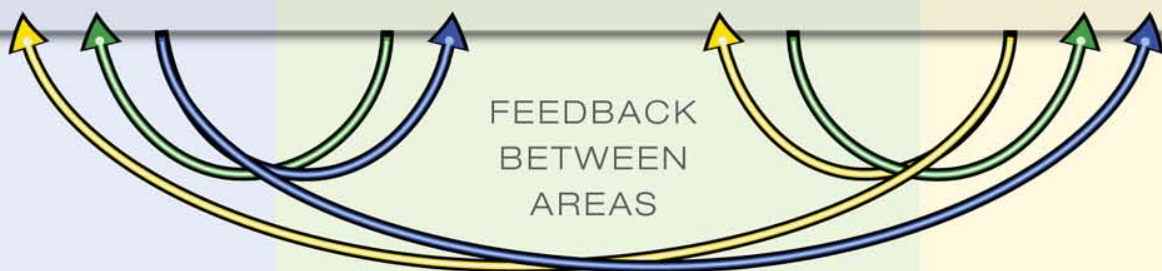

1. Develop and maintain a National Template of Vehicle Codes and Standards for each alternative fuel.

2. Participate directly on codes and standards technical committees.

3. Identify gaps in the codes and standards and plan research to fill these gaps.

4. Harmonize domestic and international standards on an as needed basis.
1. Evaluate safety sensor performance according to established DOE performance criteria and distribute information to improve sensor performance.

\section{Perform research identified under} the codes and standards template gap analysis primarily within DOE laboratory facilities.

3. Work directly with the codes and standards technical committees to implement research products into the codes and standards.

4. Maintain and upgrade laboratory to meet the codes and standards research demands.
1. Produce web based training and information products to support the application of codes and standards.

2. Perform Codes and Standards training at NREL utilizing the Wind Site and other vehicle projects.

3. Perform regional codes and standards workshops.

4. From workshop feedback identify needed code changes and research projects.

5. Perform project codes and standards analyses and third party safety evaluations.

6. Support the Clean Cities Program.

Figure 1: The NREL Vehicle Codes and Standards Project 


\section{Vehicle Technologies Codes and Standards Development Process}

Directed by NREL Codes and Standards Project Manager

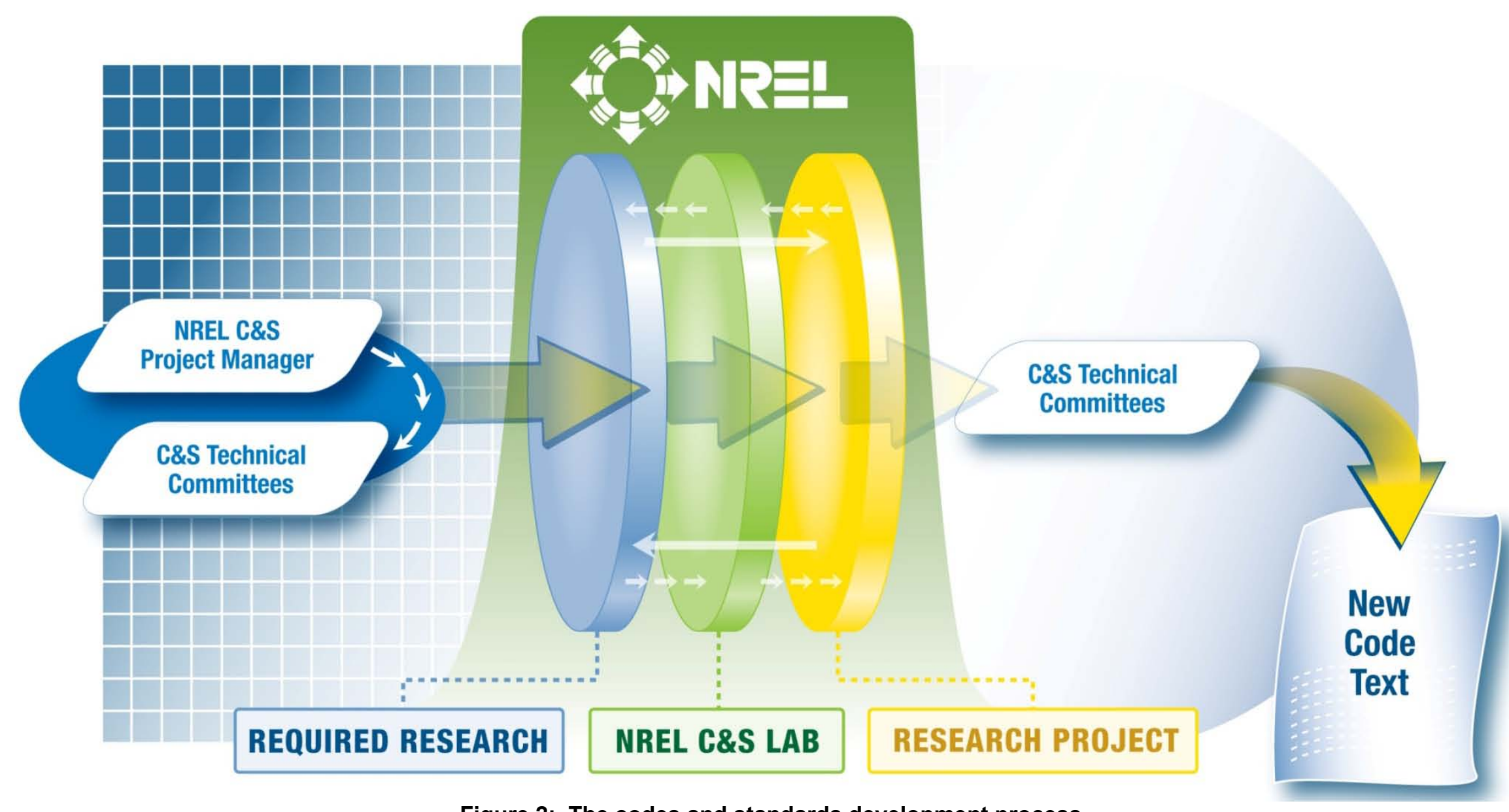

Figure 2: The codes and standards development process 


\section{PROPANE}




\section{Propane $^{1}$}

\section{Background}

Propane has been used as a vehicle fuel on a widespread basis for many years, with significant interest growing shortly after World War II [6]. As a result of this long history, the codes and standards for Propane are well established, but by no means comprehensive. The utilization of Propane as a vehicular fuel has been growing in the past decade. Figure 3 shows that the number of Propane vehicles has increased steadily from 1995 through 2002 [7]. In Figure 3, it should be noted that the 2001 value given is preliminary and the 2002 value is a projected estimate.

Current information regarding fueling infrastructure, costs, fuel prices, and related topics is readily available to the public at the Alternative Fuels and Advanced Vehicles Data Center [8]. The following link provides a list of existing Propane fueling facilities: http://www.afdc.energy.gov/afdc/fuels/propane locations.html.

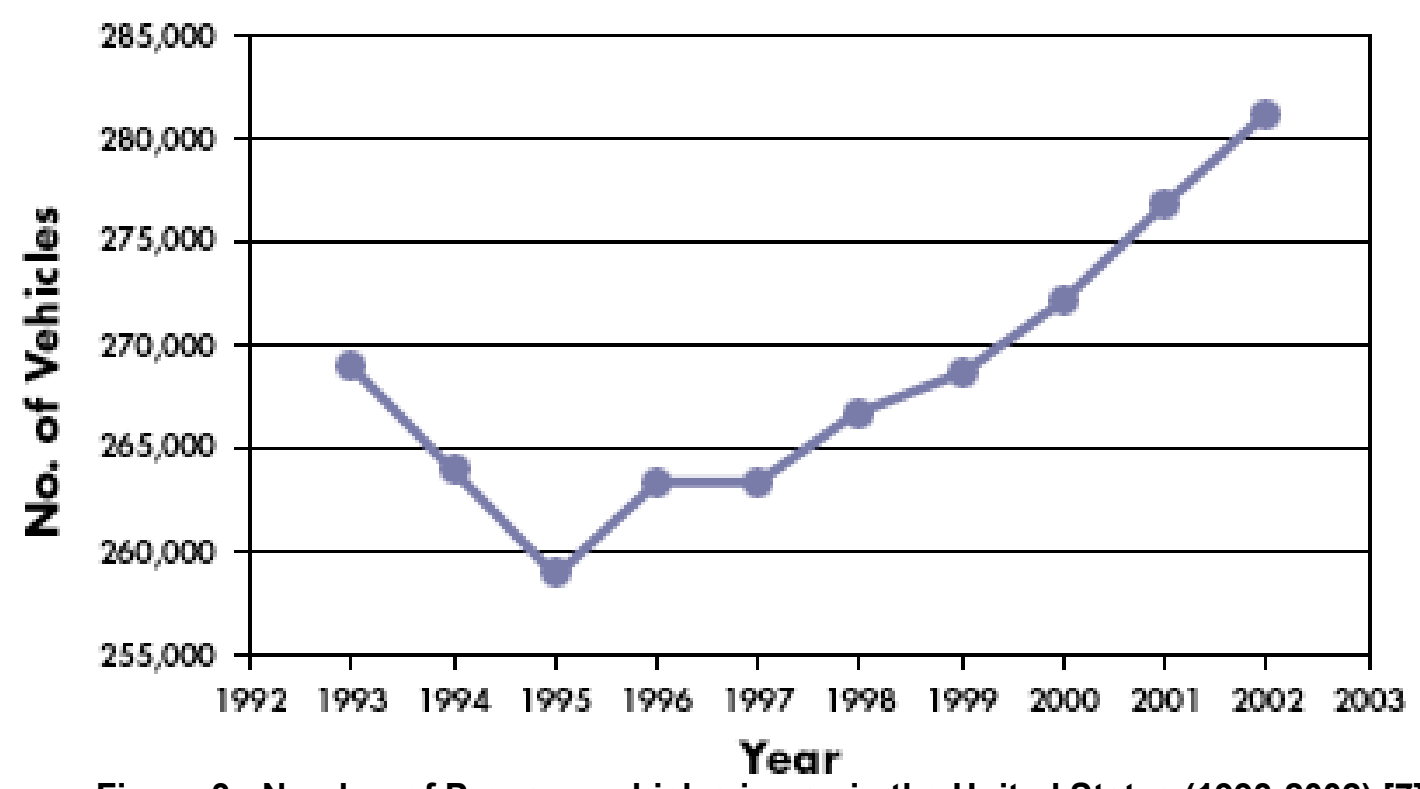

\section{Codes and Standards Structure}

NFPA 58, the Liquefied Petroleum Gas Code, was created in 1932 [9]. After World War II, interest in Propane vehicles grew, particularly for fleet vehicles and industrial fork trucks. Consequently, NFPA 58 was modified to encompass Propane vehicle requirements. Since then, some minor revisions to NFPA 58 have occurred. As a result of the comparatively long history of Propane use as a vehicle fuel, the Propane codes and standards are more established and the user market is more familiar with the pertinent codes and standards relative to other alternative fuel types. NFPA 58 is used throughout the United States and has been directly adopted as a regulation (e.g., a code) by most

\footnotetext{
${ }^{1}$ Expert discussion on the use of Propane as an alternative fuel, included herein, was provided by Ted Lemoff.
} 
states. This document sets specifications for storage, dispensing, onboard vehicle requirements, and infrastructure requirements for Propane. Table 4 presents code citations from NFPA 58 as well as the documents referenced in NFPA 58. The existing infrastructure is also well established. Therefore, AHJs are sufficiently familiar with the permitting of associated fueling facilities.

Table 4: Code citations in NFPA 58 for Propane

\section{Codes and Standards Citations for Propane Fuel}

\section{GENERAL REQUIREMENTS}

NFPA 58, Liquefied Petroleum Gas Code, 4

Acceptance of Equipment and Systems

NFPA 58, Liquefied Petroleum Gas Code, 4.1

Odorization

NFPA 58, Liquefied Petroleum Gas Code, 4.2

Notification of Installations

NFPA 58, Liquefied Petroleum Gas Code, 4.3

Qualification of Personnel

NFPA 58, Liquefied Petroleum Gas Code, 4.4

Ammonia Contamination

NFPA 58, Liquefied Petroleum Gas Code, 4.5

Minimum Requirements

NFPA 58, Liquefied Petroleum Gas Code, 4.6

\section{GAS EQUIPMENT AND APPLIANCES}

NFPA 58, Liquefied Petroleum Gas Code, 5

Containers

NFPA 58, Liquefied Petroleum Gas Code, 5.2

American Society of Mechanical Engineers (ASME) Boiler and

Pressure Vessel Code, Section VIII, "Rules for the Construction of Unfired Pressure Vessels"

American Petroleum Institute (API)-ASME Code for Unfired Pressure

Vessels for Petroleum Liquids and Gases,

National Board Inspection Code

Compressed Gas Association (CGA) C-6, Standard for Visual

Inspection of Steel Compressed Gas Cylinders

American Society of Civil Engineers (ASCE) 7, Minimum Design

Loads for Buildings and Other Structures

Container Appurtenances

NFPA 58, Liquefied Petroleum Gas Code, 5.7

Underwriters' Laboratories, Inc. (UL) 132, Standard on Safety Relief

Valves for Anhydrous Ammonia and Liquefied Petroleum Gas

UL 144, Standard for Liquefied Petroleum Gas Regulators

NFPA 54, National Fuel Gas Code (ANSI Z223.1), 5.9.2

UL 651, Schedule 40 or 80 Rigid PVC Conduit 


\section{Codes and Standards Citations for Propane Fuel}

CGA V-1, Standard Compressed Gas Cylinder Valve Outlet and Inlet Connections

API 607, Fire Test for Soft-Seated Quarter Turn Ball Valves

Piping (including Hose), Fittings and Valves

NFPA 58, Liquefied Petroleum Gas Code, 5.8

NFPA 54, National Fuel Gas Code

Referenced American Society for Testing and Materials (ASTM)

Piping and Tubing Standards

Valves Other Than Container Valves

NFPA 58, Liquefied Petroleum Gas Code, 5.10

Referenced ASTM Standards

Hydrostatic Relief Valves

NFPA 58, Liquefied Petroleum Gas Code, 5.11

Referenced ASTM Standards

Equipment

NFPA 58, Liquefied Petroleum Gas Code, 5.15

Referenced ASTM Standards

\section{INSTALLATION OF LP GAS SYSTEMS}

NFPA 58, Liquefied Petroleum Gas Code, 6

Scope

NFPA 58, Liquefied Petroleum Gas Code, 6.1

Location of Containers

NFPA 58, Liquefied Petroleum Gas Code, 6.2

Container Separation Distances

NFPA 58, Liquefied Petroleum Gas Code, 6.3

Other Container Location Requirements

NFPA 58, Liquefied Petroleum Gas Code, 6.4

NFPA 30, Flammable and Combustible Liquids Code

NFPA 55, Compressed Gases and Cryogenic Fluids Code

ANSI/CGA C-7, Guide to the Preparation of Precautionary Labeling and Marking of Compressed Gas Containers

Location of Transfer Operations

NFPA 58, Liquefied Petroleum Gas Code, 6.5

Installation of Containers

NFPA 58, Liquefied Petroleum Gas Code, 6.6

NFPA 220, Standard on Types of Building Construction

Installation of Containers Appurtenances

NFPA 58, Liquefied Petroleum Gas Code, 6.7

ANSI Z21.80/Codes and Standards of America (CSA) 6.22, Standard

for Line Pressure Regulators.

NFPA 54, National Fuel Gas Code

Piping Systems

NFPA 58, Liquefied Petroleum Gas Code, 6.8 


\section{Codes and Standards Citations for Propane Fuel}

ASME B 31.3, Process Piping

ASME Boiler and Pressure Vessel Code, Section IX

References ASTM Piping Standards

Internal Valves

NFPA 58, Liquefied Petroleum Gas Code, 6.9

Emergency Shutoff Valves

NFPA 58, Liquefied Petroleum Gas Code, 6.10

Hydrostatic Relief Valve Installation

NFPA 58, Liquefied Petroleum Gas Code, 6.11

Testing Piping Systems

NFPA 58, Liquefied Petroleum Gas Code, 6.12

ASME Boiler and Pressure Vessel Code, Section IX

Installation in Areas with Heavy Snowfall

NFPA 58, Liquefied Petroleum Gas Code, 6.13

Corrosion Protection

NFPA 58, Liquefied Petroleum Gas Code, 6.14

Equipment Installation

NFPA 58, Liquefied Petroleum Gas Code, 6.15

Bulk Plant and Industrial Liquefied Petroleum Gas Systems

NFPA 58, Liquefied Petroleum Gas Code, 6.16

Liquefied Petroleum Gas Systems in Buildings or on Roofs

NFPA 58, Liquefied Petroleum Gas Code, 6.17

UL 147A, Standard for No refillable (Disposable) Type Fuel Gas

Cylinder Assemblies

UL 147B, Standard for No Refillable (Disposal) Type Metal Container

Assemblies for Butane

Ignition Source Control

NFPA 58, Liquefied Petroleum Gas Code, 6.20

NFPA 70, National Electrical Code

Vehicle Fuel Dispenser and Dispensing Stations

NFPA 58, Liquefied Petroleum Gas Code, 6.22

UL 567, Standard Pipe Connectors for Flammable and Combustible

Liquids and Liquefied Petroleum Gas

Fire Protection

NFPA 58, Liquefied Petroleum Gas Code, 6.23

NFPA 15, Standard for Water Spray Fixed Systems for Fire

Protection

Alternate Provisions for Installation of ASME Containers

NFPA 58, Liquefied Petroleum Gas Code, 6.24

\section{LIQUEFIED PETROLEUM GAS LIQUID TRANSFER}

NFPA 58, Liquefied Petroleum Gas Code, 7

Scope

NFPA 58, Liquefied Petroleum Gas Code, 7.1 


\section{Codes and Standards Citations for Propane Fuel}

Operational Safety

NFPA 58, Liquefied Petroleum Gas Code, 7.2

Venting Liquefied Petroleum Gas to the Atmosphere

NFPA 58, Liquefied Petroleum Gas Code, 7.3

Quantity of Liquefied Petroleum Gas in Containers

NFPA 58, Liquefied Petroleum Gas Code, 7.4

\section{BUILDINGS OR STRUCTURES HOUSING LIQUEFIED PETROLEUM GAS FOR DISTRIBUTION}

NFPA 58, Liquefied Petroleum Gas Code, 10 Scope

NFPA 58, Liquefied Petroleum Gas Code, 10.1

Separate Structures or Buildings

NFPA 58, Liquefied Petroleum Gas Code, 10.2

NFPA 70, National Electrical Code

Attached Structures or Rooms Within Structures

NFPA 58, Liquefied Petroleum Gas Code, 10.3

\section{ENGINE FUEL SYSTEMS}

NFPA 58, Liquefied Petroleum Gas Code, 11

Scope

NFPA 58, Liquefied Petroleum Gas Code, 11.1

Training

NFPA 58, Liquefied Petroleum Gas Code, 11.2

Containers

NFPA 58, Liquefied Petroleum Gas Code, 11.3

U.S. Department of Transportation (DOT)

Rules for Construction of Unfired Pressure Vessels," Section VIII,

Division I of the ASME Boiler and Pressure Vessel Code

Container Appurtenances

NFPA 58, Liquefied Petroleum Gas Code, 11.4

UL 132, Standard on Safety Relief Valves for Anhydrous Ammonia and Liquefied Petroleum Gas

Carburetion Equipment

NFPA 58, Liquefied Petroleum Gas Code, 11.5

Piping, Hose, and Fittings

NFPA 58, Liquefied Petroleum Gas Code, 11.6

Referenced ASTM Piping and Tubing Standards

Installation of Containers and Container Appurtenances

NFPA 58, Liquefied Petroleum Gas Code, 11.7

Installation in the Interior of Vehicles

NFPA 58, Liquefied Petroleum Gas Code, 11.8

Pipe and Hose Installation

NFPA 58, Liquefied Petroleum Gas Code, 11.9 


\section{Codes and Standards Citations for Propane Fuel}

Equipment Installation

NFPA 58, Liquefied Petroleum Gas Code, 11.10

Marking

NFPA 58, Liquefied Petroleum Gas Code, 11.11

Industrial (and Forklift) Trucks Powered by LP-Gas

NFPA 58, Liquefied Petroleum Gas Code, 11.12

General Provisions for Vehicles Having Engines Mounted on Them

NFPA 58, Liquefied Petroleum Gas Code, 11.13

Engine Installation Other Than on Vehicle

NFPA 58, Liquefied Petroleum Gas Code, 11.14

Garaging of Vehicles

NFPA 58, Liquefied Petroleum Gas Code, 11.15

\section{OPERATIONS AND MAINTENANCE}

NFPA 58, Liquefied Petroleum Gas Code, 14

Scope

NFPA 58, Liquefied Petroleum Gas Code, 14.1

Operating Requirements

NFPA 58, Liquefied Petroleum Gas Code, 14.2

Maintenance

NFPA 58, Liquefied Petroleum Gas Code, 14.3

NFPA 25, Standard for the Inspection, Testing, and Maintenance of

Water-Based Fire Protection Systems

NFPA 10, Standard for Portable Fire Extinguishers

PIPING AND TUBING SIZING TABLES

NFPA 58, Liquefied Petroleum Gas Code, 15 


\section{Gaps in Codes and Standards}

Since the use of Propane as a vehicle fuel is well established, relatively few gaps in the associated codes and standards exist that impede the widespread implementation and use of as a vehicle fuel. Nevertheless, gaps, particularly with carburetor systems, do exist as discussed below.

\section{Conversion Kits}

The U.S. Environmental Protection Agency (EPA)-certified conversion kits, as well as Original Equipment Manufacturers (OEM) vehicles that operate on Propane fuel, are widely available. The cost of conversion of a gasoline vehicle to run on Propane fuel is relatively inexpensive when compared to that of converting to $\mathrm{CNG}$.

One gap in existing codes and standards for Propane use in vehicles is the existence of standards for conversion kits for fuel injection systems. While requirements are defined in NFPA 58 for conversion systems and associated components, they generally apply to carburetion systems only and preclude modern fuel injector engines. Groups like the Propane Education Research Council (PERC) [10] are currently pursuing activities to obtain data on fuel injection systems in order to close this gap. Collaboration with these groups could speed the promulgation of standards to address this gap.

\section{Fuel Quality}

There are significant variances in "Propane" composition. For example, Propane 2 mixtures in the range of 75 to 99 percent propane by weight and up to 23 percent propylene by weight have been reported [10]. Investigation of Propane fuel variations and their effect on emissions deterioration is required to establish the relationship between fuel composition and engine performance and emissions. For lift trucks, the EPA has a 5,000 performance hour requirement. Potentially adverse effects on performance and tail pipe emissions induced by fuel composition may also exist in passenger vehicles. At a minimum, three Propane specifications of interest have been defined [10] as follows: Heavy Duty (propane) containing a maximum of 5 percent propylene and 2.5 percent butane (HD-5) as defined in ANSI/ASTM D 1835-97, the California specification, which is similar to HD-5 but allowing up to 10 percent propylene and up to 5 percent butane, and finally the commercial Propane specification, which is defined as what is commercially available in the marketplace.

As a manufactured product, Propane has inherently low-sulfur content (generally less than 10 parts per million [ppm] by weight). However, the addition of ethyl mercaptan as an odorant will increase the sulfur content and may impact the durability of exhaust gas after-treatment systems (e.g., the catalytic converter catalyst and other systems).

Therefore, interest lies in developing a specification on the level of sulfur that will satisfy odorant requirements while not poisoning catalysts. The range of interest is between 10 to 120 ppm total sulfur compounds [10].

\footnotetext{
${ }^{2}$ The alternative fuel Propane is comprised of a mixture of chemicals. The dominant chemical species is propane $\left(\mathrm{C}_{3} \mathrm{H}_{8}\right)$ blended with numerous other chemicals. Within this report, the alternative fuel is always represented with a capital first letter to distinguish it from a specific chemical (e.g., Propane vs. propane).
} 
Several fuel additives are commercially available that claim to mitigate the effects of residual contaminates in commercial Propane [10]. Commonly referred to as "heavy ends," these residues are predominantly olefin-based deposits that can accumulate inside fuel systems. Their impact on fuel system durability and emissions deterioration is also important.

Providing research data for developing or revising Propane fuel quality standards is a likely solution for this gap. Collaboration of the National Laboratories with efforts already underway in the areas of fuel composition, effects of fuel sulfur on catalysts, and the impact of additives would facilitate the acquisition and dissemination of data critical to defining specifications for code and standard development for Propane composition.

\section{Infrastructure}

Another barrier for the more widespread use of Propane as a motor fuel is the inability to increase distribution volume at existing locations. If the Propane demand were to increase significantly, the existing supply and transportation of Propane to existing distribution facilities would be inadequate. Thus, a sudden increase in the Propane fleet size could stress the Propane distribution infrastructure, possibly leading to fuel shortages. This is not a trivial matter since many isolated communities in the United States rely on Propane for heating and cooking. Thus the impact of fuel shortages, arising from either a real shortage or from an inadequate distribution system, could be significant. The key to filling this potential gap is collaboration with suppliers and analysis groups.

\section{Summary}

Table 5 presents a summary of the identified Code and Standards Gaps for the expanded use of Propane as an alternative fuel. Also included in the table is the impacted document and proposed means to address the gap.

Table 5: Codes and Standards Gaps for Propane

\begin{tabular}{|c|c|c|}
\hline Vehicle Codes and Standards Gap & $\begin{array}{l}\text { Documents } \\
\text { Impacted }\end{array}$ & Gap Resolution \\
\hline Conversion Components & $\begin{array}{l}\text { NFPA } 58 \text { or UL } \\
\text { listing document }\end{array}$ & $\begin{array}{l}\text { Provide data to ensure } \\
\text { component listings are } \\
\text { valid }\end{array}$ \\
\hline Compositional and fuel quality concerns & ASTM D 1835-97 & $\begin{array}{l}\text { Provide data from the } \\
\text { analysis of fuel quality and } \\
\text { impact on vehicle systems }\end{array}$ \\
\hline $\begin{array}{l}\text { Infrastructure capacity as the Propane } \\
\text { vehicle fleet grows }\end{array}$ & $\begin{array}{l}\text { Multiple } \\
\text { documents } \\
\text { including NFPA } \\
58\end{array}$ & $\begin{array}{l}\text { Collaborate with suppliers } \\
\text { and national laboratory } \\
\text { analysis groups }\end{array}$ \\
\hline
\end{tabular}


NATURAL GAS

(NG) 


\section{Natural Gas (NG) ${ }^{3}$}

\section{Background}

Although NG has been used as a vehicle fuel since the 1940s, it was only in the late 1970 s that NG became widely used in the United States [11]. Many of the first NG vehicles in the United States were part of fleets operated by the gas utility companies. Other vehicles were part of municipal fleets.

The interest in natural gas as an alternative transportation fuel stems mainly from its clean-burning qualities, its domestic resource base, and its commercial availability. Because of the gaseous nature of this fuel, it must be stored onboard a vehicle in either a compressed gaseous (compressed natural gas, $\mathrm{CNG}$ ) or liquefied (liquefied natural gas, LNG) state.

Worldwide, nearly 8.7 million NG-powered vehicles exist, but only roughly 150,000 are in the United States. Table 6 shows the distribution of CNG vehicles deployed in leading countries [12]. Currently, the use of $\mathrm{NG}$ as an alternative vehicle fuel is more important internationally than nationally. The size of the NG fleet in the United States is likely to increase due to the increase in domestic reserves and resulting favorable economic status.

Information regarding OEM new vehicles, fueling infrastructure, costs, fuel prices, and related information is readily available to the public at the Alternative Fuels and Advanced Vehicles Data Center [13]. The following link provides a list of existing NG fueling facilities: http://www.afdc.energy.gov/afdc/fuels/natural_gas locations.html.

Table 6: CNG Vehicles

\begin{tabular}{|ll|ll|}
\hline \multicolumn{3}{|c|}{ Locations and Approximate Number of CNG Vehicles } \\
\hline Argentina & $1,690,000$ & Pakistan & $1,650,000$ \\
\hline Brazil & $1,510,000$ & Europe & 812,000 \\
\hline Iran & 611,500 & India & 354,000 \\
\hline Colombia & 251,700 & China & 200,900 \\
\hline Bangladesh & 150,000 & USA & 150,000 \\
\hline Ukraine & 120,000 & Russia & 95,000 \\
\hline Bolivia & 84,100 & Egypt & 81,400 \\
\hline Venezuela & 44,100 & Canada & 12,100 \\
\hline
\end{tabular}

Sources: Gas Vehicles Report, May 2008, www.iangv.org/tools-resources/statistics.html.

${ }^{3}$ Expert discussion on the use of NG as an alternative fuel, included herein, was provided by Larry Fluer and Douglas Horne. 


\section{Codes and Standards Structure}

Historically, the codes and standards for $\mathrm{CNG}$ were based on best practices publications produced by the natural gas industry and the utilities. In 1984 NFPA published NFPA 52 the standards for the use of CNG. Eventually, fuel-specific standards were produced by CSA and SAE. Table 7 provides a summary of codes and standards that apply to CNG.

Table 7: Code and Standards for CNG

\section{Codes and Standards Citations for Compressed Natural Gas Fuel}

Fire Code Requirements

Approvals

International Fire Code IFC) 2208.2

Location of dispensing operations and equipment IFC 2208.3

Private fueling of motor vehicles

IFC 2208.4

Pressure regulators

IFC 2208.5

Valves

IFC 2208.6

Emergency shutdown control

IFC 2208.7

Discharge of CNG from motor vehicle storage containers

IFC 2208.9

Containers, cylinders, and tanks (general)

IFC

Containers, cylinders, and tanks

IFC 3003.1

Design and construction

IFC 3003.2

Pressure relief devices

IFC 3003.3

Marking

IFC 3003.4

Security

IFC 3003.5

Valve protection

IFC 3003.6

Separation from hazardous conditions

IFC 3003.7

Wiring and equipment

IFC 3003.8

Service and repair

IFC 3003.9

Unauthorized use

IFC 3003.1 


\section{Codes and Standards Citations for Compressed Natural Gas Fuel}

Exposure to fire

IFC 3003.11

Leaks, damage, or corrosion

IFC 3003.12

Surface of unprotected storage or use areas

IFC 3003.13

Overhead cover

IFC 3003.14

Lighting

IFC 3003.15

Vaults

IFC 3003.16

\section{General CNG Requirements and Equipment Qualifications}

Composition

NFPA 52 Gaseous Fuel Vehicular Systems Code 4.2

System Approvals

NFPA 52 Gaseous Fuel Vehicular Systems Code 4.3

Design and Construction of Containers

NFPA 52 Gaseous Fuel Vehicular Systems Code 4.4

Pressure Relief Devices

NFPA 52 Gaseous Fuel Vehicular Systems Code 4.5

Pressure Gauges

NFPA 52 Gaseous Fuel Vehicular Systems Code 4.6

Pressure Regulators

NFPA 52 Gaseous Fuel Vehicular Systems Code 4.7

Fuel Lines

NFPA 52 Gaseous Fuel Vehicular Systems Code 4.8 Valves

NFPA 52 Gaseous Fuel Vehicular Systems Code 4.9 Hose and Hose Connections

NFPA 52 Gaseous Fuel Vehicular Systems Code 4.1 Vehicle Fueling Connection

NFPA 52 Gaseous Fuel Vehicular Systems Code 4.11

\section{CNG Engine Fuel Systems}

System Component Qualifications

NFPA 52 Gaseous Fuel Vehicular Systems Code 6.2 Installation of Fuel Supply Containers

NFPA 52 Gaseous Fuel Vehicular Systems Code 6.3 Installation of Venting Systems

NFPA 52 Gaseous Fuel Vehicular Systems Code 6.4 Installation of Piping

NFPA 52 Gaseous Fuel Vehicular Systems Code 6.5 


\section{Codes and Standards Citations for Compressed Natural Gas Fuel}

Installation of Valves

NFPA 52 Gaseous Fuel Vehicular Systems Code 6.6 Installation of Pressure Gauges

NFPA 52 Gaseous Fuel Vehicular Systems Code 6.7 Installation of Pressure Regulators

NFPA 52 Gaseous Fuel Vehicular Systems Code 6.8 Installation of Fueling Connection

NFPA 52 Gaseous Fuel Vehicular Systems Code 6.9 Wiring Installation

NFPA 52 Gaseous Fuel Vehicular Systems Code 6.1 Labeling

NFPA 52 Gaseous Fuel Vehicular Systems Code 6.11 System Testing

NFPA 52 Gaseous Fuel Vehicular Systems Code 6.12 System Maintenance and Repair

NFPA 52 Gaseous Fuel Vehicular Systems Code 6.13 Discharge from Vehicle Containers

NFPA 52 Gaseous Fuel Vehicular Systems Code 6.14

\section{CNG Compression, Gas Processing, Storage, and Dispensing Systems}

System Component Qualifications

NFPA 52 Gaseous Fuel Vehicular Systems Code 8.2 General System Requirements

NFPA 52 Gaseous Fuel Vehicular Systems Code 8.3 System Siting

NFPA 52 Gaseous Fuel Vehicular Systems Code 8.4 Installation of Containers and Container Appurtenances (Other than Pressure Relief Devices)

NFPA 52 Gaseous Fuel Vehicular Systems Code 8.5 Installation of Pressure Relief Devices

NFPA 52 Gaseous Fuel Vehicular Systems Code 8.6 Installation of Pressure Regulators

NFPA 52 Gaseous Fuel Vehicular Systems Code 8.7 Installation of Pressure Gauges

NFPA 52 Gaseous Fuel Vehicular Systems Code 8.8 Installation of Piping and Hoses

NFPA 52 Gaseous Fuel Vehicular Systems Code 8.9 System Testing

NFPA 52 Gaseous Fuel Vehicular Systems Code 8.1 Installation of Emergency Shutdown Equipment

NFPA 52 Gaseous Fuel Vehicular Systems Code 8.11 Installation of Electrical Equipment

NFPA 52 Gaseous Fuel Vehicular Systems Code 8.12 


\section{Codes and Standards Citations for Compressed Natural Gas Fuel}

Installation of Electrical Equipment

NFPA 52 Gaseous Fuel Vehicular Systems Code 8.13

System Operation

NFPA 52 Gaseous Fuel Vehicular Systems Code 8.14

Fire Protection

NFPA 52 Gaseous Fuel Vehicular Systems Code 8.15

System Maintenance

NFPA 52 Gaseous Fuel Vehicular Systems Code 8.16

Vehicle Fueling Appliances in Nonresidential Occupancies

NFPA 52 Gaseous Fuel Vehicular Systems Code 8.17

\section{CNG Residential Fueling Facilities}

NFPA 52 Gaseous Fuel Vehicular Systems Code

System Component Qualifications

NFPA 52 Gaseous Fuel Vehicular Systems Code 10.2 General Safety Requirements

NFPA 52 Gaseous Fuel Vehicular Systems Code 10.3 Installation

NFPA 52 Gaseous Fuel Vehicular Systems Code 10.4 Installation of Pressure Relief Valves

NFPA 52 Gaseous Fuel Vehicular Systems Code 10.5 Installation of Pressure Gauges

NFPA 52 Gaseous Fuel Vehicular Systems Code 10.6 Pressure Regulation

NFPA 52 Gaseous Fuel Vehicular Systems Code 10.7 Piping and Hose

NFPA 52 Gaseous Fuel Vehicular Systems Code 10.8 Testing

NFPA 52 Gaseous Fuel Vehicular Systems Code 10.9 Installation of Emergency Shutdown Equipment

NFPA 52 Gaseous Fuel Vehicular Systems Code 10.1 Operation

NFPA 52 Gaseous Fuel Vehicular Systems Code 10.11 Maintenance and Inspection

NFPA 52 Gaseous Fuel Vehicular Systems Code 10.12

\section{CNG Component Standards}

\section{CSA America}

Natural Gas Vehicle (NGV) 2 Natural Gas Vehicle Containers

NGV 1 Compressed NGV Fueling Connection Devices

NGV 3.1Fuel System Components for Natural Gas Powered Vehicles

NGV 4.1 Dispensing Systems

NGV 4.2 Hoses for Natural Gas Vehicles and Dispensing Systems 


\section{Codes and Standards Citations for Compressed Natural Gas Fuel}

NGV 4.3 Temperature Compensation Devices for Natural Gas Dispensing Systems

NGV 4.4 Breakaway Devices for Natural Gas Dispensing Hoses and Systems

NGV 4.5 (draft) Priority and Sequencing Equipment for Natural Gas Dispensing Systems

NGV 4.6 Manually Operated Valves for Natural Gas Dispensing Systems

NGV 4.7 (draft) Automatic Valves for Use in Natural Gas Vehicle Fueling Stations

NGV 4.8 Natural Gas Fueling Station Reciprocating Compressor Guidelines

Pressure Relief Devices (PRD) -1 for NGV Fuel Container ASME

ASME B31.3 Process Piping

Boiler and Pressure vessel Code

CGA

C-6 Standards for Visual Inspection of Steel Compressed Gas

Cylinders

S-1.1 Pressure Relief Device Standards - Part 1- Cylinders for Compressed Gases

S-1.3 Pressure Relief Device Standards - Part 3 - Stationary Storage

Containers for Compressed Gases

SAE

J1616 RP for Compressed Natural Gas Vehicle Fuel

J 2406 RP for CNG Powered Medium and Heavy Duty Trucks 


\section{Gaps in Codes and Standards}

Like Propane, the use of NG as a motor fuel is well established and relatively few gaps are present in the existing codes and standards that prevent its widespread use. Although the existing fueling infrastructure is not widespread, it is technically understood by both producers and AHJs that the permitting and installation of associated fueling facilities must be a straight-forward process, both technically and with regard to regulatory code compliance.

\section{Conversion Kits}

One potential barrier to more widespread use of NG as a motor fuel may be the expense for the conversion of an existing gasoline vehicle to NG fuel. The CNG tanks represent the bulk of the expense for converting a vehicle.

Another concern is the converted vehicle's compliance to EPA regulations. While conversion information does exist, the expense regarding EPA certification of components impedes widespread conversion to NG from gasoline. Reducing the cost for vehicle conversions would lead to an increase in NG consumer vehicles.

Another potential impediment for increased NG vehicle deployment is that while the technician knowledge relative to NG conversion installation and vehicle maintenance for natural gas vehicles exists through training programs and technician certification through the Automotive Service Excellence's (ASE's) national program, the same certification process for conversion shops is lacking. Continuing public outreach efforts and NG use education products and activities would address knowledge gaps from the consumer level to public code officials and automotive technicians.

\section{Infrastructure}

In general, CNG's supply and delivery system is well established. However, the CNG infrastructure has not developed for light-duty vehicle applications but instead focused on high-fuel-use fleet applications. In the United States, relatively few CNG light-duty vehicles are available for purchase from dealerships by consumers. Fueling infrastructure is likely one reason automotive manufacturers are reluctant to produce CNG light-duty vehicles. One company has offered a CNG vehicle as well as a small home refueling unit [14]. However, the refueling system was discontinued by the original company. Although the product line was licensed to a new company, its availability is uncertain and there may be issues with the application of excise taxing for the road use of fuel.

\section{Component Compatibility}

Also used for many years as a mechanism for on-board storage and delivering fuel to an engine is Liquefied Natural Gas (LNG). Several codes and standards gaps associated with LNG use exist. Because of the existing market size, there is a lack of manufacturing infrastructure, with only a limited number of manufacturers that produce equipment for the LNG market. In the United States, the primary standard for LNG is NFPA 52 with additional standards developed or under development by SAE, such as J2343 for LNG Heavy Duty Trucks, SAE 2699 for LNG Fuel Composition, J2645 for LNG Dispensers and under development J2700 for LNG Tanks and J1740 for LNG Fueling Connectors. Additionally, several LNG standards issues are currently being addressed at the 
international level (i.e., ISO [15] and United Nations (UN) Global Technical Regulations [16]). Two components currently under international assessment are LNG tanks and connectors. National Laboratory participation on ISO, UN, and domestic (CSA, NFPA, ASME, SAE) technical committees responsible for writing component standards for LNG connectors, tanks, and components would help alleviate gaps in LNG component standards. This participation also ensures that national interests and concerns are considered during drafting of the international standards. Maintaining membership in such committees also enables the National Laboratories to determine the types of research and data required by committee members to produce sound codes and standards. Performing research at the component level (tanks, connectors, sensors, etc.) and providing technical data to the appropriate standards technical committees offers great value to standards groups addressing gaps.

Also, the use of CNG in forklift applications has potential for emissions and cost savings. However, some standards gaps exist associated with the language in UL 558 [17] and NFPA 505 [18], specifically concerning the CNG tanks used for this application.

\section{Summary}

Table 8 presents a summary of the identified Code and Standards Gaps for the expanded use of CNG as an alternative fuel. Also, presented in the table is the impacted document and proposed means to address the gap.

Table 8: Codes and Standards Gaps for NG

\begin{tabular}{|l|l|l|}
\multicolumn{1}{|c|}{$\begin{array}{l}\text { Vehicle Codes and } \\
\text { Standards Gap }\end{array}$} & $\begin{array}{c}\text { Documents } \\
\text { Impacted }\end{array}$ & \multicolumn{1}{c|}{ Gap Resolution } \\
\hline $\begin{array}{l}\text { Lack of available commercial } \\
\text { CNG-powered vehicles }\end{array}$ & Multiple & $\begin{array}{l}\text { Explore government assistance options } \\
\text { for increasing the availability of CNG } \\
\text { vehicles }\end{array}$ \\
\hline $\begin{array}{l}\text { Limited sources for LNG } \\
\text { components }\end{array}$ & Multiple & $\begin{array}{l}\text { Explore government assistance options } \\
\text { for increasing the availability of LNG } \\
\text { components }\end{array}$ \\
\hline $\begin{array}{l}\text { High costs for EPA-certified } \\
\text { conversion }\end{array}$ & Multiple & $\begin{array}{l}\text { Explore options for streamlining the EPA } \\
\text { certification process for vehicle } \\
\text { conversions as well as the availability of } \\
\text { lower-cost CNG tanks for vehicles }\end{array}$ \\
\hline $\begin{array}{l}\text { Outreach products for } \\
\text { installation technicians and } \\
\text { conversion shops }\end{array}$ & Multiple & $\begin{array}{l}\text { Produce outreach products for } \\
\text { consumers, installation shops, and } \\
\text { technicians }\end{array}$ \\
\hline $\begin{array}{l}\text { Infrastructure capacity to } \\
\text { accommodate significant } \\
\text { growth in the CNG vehicle } \\
\text { fleet }\end{array}$ & Multiple & $\begin{array}{l}\text { Explore government assistance options } \\
\text { for supporting a significant increase in } \\
\text { the use of CNG }\end{array}$ \\
\hline $\begin{array}{l}\text { Harmonize international } \\
\text { standards for components, } \\
\text { such as fittings }\end{array}$ & $\begin{array}{l}\text { NFPA } 52 \text { and } \\
\text { ISO } \\
\text { documents }\end{array}$ & $\begin{array}{l}\text { Participate in NFPA and ISO committees } \\
\text { responsible for the applicable documents }\end{array}$ \\
\hline
\end{tabular}


BIODIES EL 


\section{Biodiesel $^{4}$}

\section{Background}

The DOE characterizes biodiesel as, "a liquid fuel made up of fatty acid alkyl esters, fatty acid methyl esters (FAME), or long-chain mono alkyl esters. It is produced from renewable sources such as new and used vegetable oils and animal fats and is a cleanerburning replacement for petroleum-based diesel fuel. It is nontoxic and biodegradable. Biodiesel has physical properties similar to those of petroleum diesel" [19]. Today, approximately 600 fleets nationwide, representing over 25,000 vehicles for commercial, government, utility, and transit use, use biodiesel blends in their diesel engines [20]. Biodiesel blends are also increasingly used in the farming, mining, and marine industries, as well as for heating oil and electrical generation applications. Figure 4 illustrates the increasing popularity of biodiesel in a plot of the annual production. In the nine years from 2000 to 2008, the annual production of biodiesel has grown from a near-negligible level to over 700,000,000 gallons [21]. Biodiesel is available in its various blends at approximately 800 locations across the United States [20]. More information related to biodiesel fuel is available at www.biodiesel.org (EPA). The following link provides information to the public regarding OEM new vehicles, fueling infrastructure, costs, fuel prices, and other related information from the Alternative Fuels and Advanced Vehicles Data Center [22]: http://www.afdc.energy.gov/afdc/fuels/biodiesel locations.html.

\section{Estimated US Biodiesel Production by Fiscal Year (Oct 1 - Sept 30)}

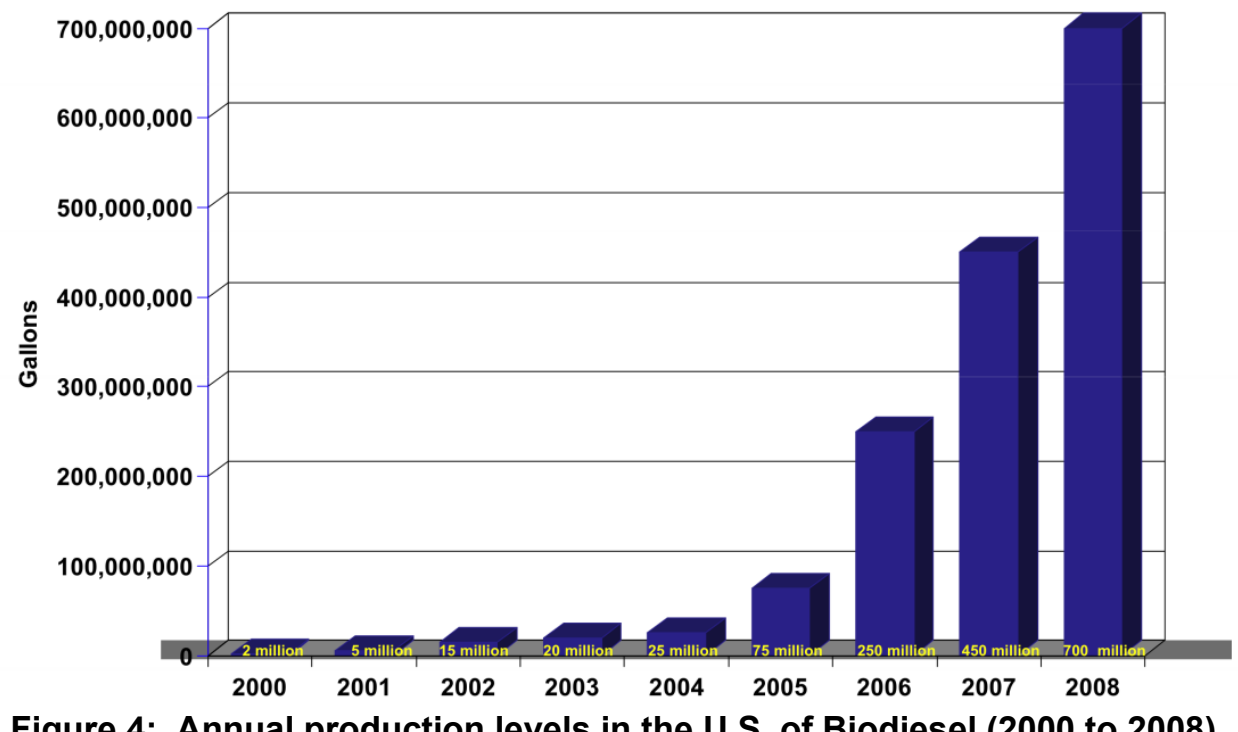

Figure 4: Annual production levels in the U.S. of Biodiesel (2000 to 2008)

\footnotetext{
${ }^{4}$ Expert discussion on the use of Biodiesel as an alternative fuel, included herein, was provided by Robert McCormick.
} 


\section{Codes and Standards Structure}

The codes and standards structure for Biodiesel is relatively straightforward. NFPA 30, The Flammable and Combustible Liquids Code [23], and NFPA 30A, The Code for Motor Fuel Dispensing Facilities and Repair Garages [24], are both used throughout the United States and directly adopted as regulations by most states. These documents set requirements for storage, dispensing, onboard vehicle requirements, as well as infrastructure requirements for Biodiesel. In addition, the International Building Code (IBC) is generally adopted and used as the building code in most jurisdictions. The IBC also applies to infrastructure. Table 9 lists code citations from NFPA 30 and 30A as well as the documents referenced therein.

Table 9: Codes and Standards for Biodiesel

\section{Codes and Standards Citations for Biodiesel Fuel}

\section{DEFINITION AND CLASSIFICATION OF LIQUIDS}

Scope

NFPA 30, Flammable and Combustible Liquids Code, 4.1

Definitions

NFPA 30, Flammable and Combustible Liquids Code, 4.2

ASTM Standard Test Methods

Classification of Liquids

NFPA 30, Flammable and Combustible Liquids Code, 4.3

ASTM Standard Test Methods

Determination of Flash Point

NFPA 30, Flammable and Combustible Liquids Code, 4.4

ASTM Standard Test Methods

Relationship to Other Classification Systems

NFPA 30, Flammable and Combustible Liquids Code, 4.5

\section{FIRE PREVENTION AND FIRE RISK CONTROL}

Scope

NFPA 30, Flammable and Combustible Liquids Code, 6.1

\section{Definitions}

NFPA 30, Flammable and Combustible Liquids Code, 6.2 Management of Fire and Explosion Hazards

NFPA 30, Flammable and Combustible Liquids Code, 6.3

NFPA 69, Standard on Explosion Prevention Systems

NFPA 68, Standard on Explosion Protection by Deflagration Venting Hazards Analysis

NFPA 30, Flammable and Combustible Liquids Code, 6.4 Control of Ignition Sources

NFPA 30, Flammable and Combustible Liquids Code, 6.5

NFPA 51B, Standard for Fire Prevention During Welding, Cutting, and Other Hot Work

NFPA 77, Recommended Practice on Static Electricity 


\section{Codes and Standards Citations for Biodiesel Fuel}

Detection and Alarm Systems

NFPA 30, Flammable and Combustible Liquids Code, 6.6

NFPA 72, National Fire Alarm Code

Fire Protection and Suppression Systems

NFPA 30, Flammable and Combustible Liquids Code, 6.7

NFPA 24, Standard for the Installation of Private Fire Service Mains and Their Appurtenances

NFPA 13, Standard for the Installation of Sprinkler Systems

NFPA 10, 11, 12, 12A, 14, 15, 16, 17, 2001

Emergency Planning and Training

NFPA 30, Flammable and Combustible Liquids Code, 6.8

Inspection and Maintenance

NFPA 30, Flammable and Combustible Liquids Code, 6.9

NFPA 25, Standard for the Inspection, Testing, and Maintenance of

Water-Based Fire Protection Systems

Management of Security

NFPA 30, Flammable and Combustible Liquids Code, 6.10

\section{BUILDING CONSTRUCTION REQUIREMENTS}

Scope

NFPA 30A, Code for Motor Fuel Dispensing Facilities and Repair Garages, 7.1

General Requirements

NFPA 30A, Code for Motor Fuel Dispensing Facilities and Repair

Garages, 7.2

Motor Fuel Dispensing Facilities

NFPA 30A, Code for Motor Fuel Dispensing Facilities and Repair

Garages, 7.3

NFPA 101, Life Safety Code

NFPA 220, Standard on Types of Building Construction

NFPA 80, Standard for Fire Doors and Other Opening Protective's

NFPA 91, Standard for Exhaust Systems for Air Conveying of Vapors,

Gases, Mists, and Noncombustible Particulate Solids

Repair Garages

NFPA 30A, Code for Motor Fuel Dispensing Facilities and Repair Garages, 7.4

NFPA 101, Life Safety Code

NFPA 13, Standard for the Installation of Sprinkler Systems

NFPA 90A, Standard for the Installation of Air-Conditioning and Ventilation Systems

Heating, Ventilation, and Air-Conditioning

NFPA 30A, Code for Motor Fuel Dispensing Facilities and Repair Garages, 7.5 


\section{Codes and Standards Citations for Biodiesel Fuel}

Heat-Producing Appliances

NFPA 30A, Code for Motor Fuel Dispensing Facilities and Repair

Garages, 7.6

Dynamic Automotive Emissions Testing Equipment

NFPA 30A, Code for Motor Fuel Dispensing Facilities and Repair Garages, 7.7

\section{ELECTRICAL SYSTEMS}

Scope

NFPA 30A, Code for Motor Fuel Dispensing Facilities and Repair Garages, 8.1

NFPA 30, Flammable and Combustible Liquids Code, 7.1

\section{Definitions}

NFPA 30, Flammable and Combustible Liquids Code, 7.2

General Requirements

NFPA 30A, Code for Motor Fuel Dispensing Facilities and Repair

Garages, 8.2

NFPA 30, Flammable and Combustible Liquids Code, 7.3

NFPA 70, National Electric Code

NFPA 497, Recommended Practice for the Classification of

Flammable Liquids, Gases, or Vapors and of Hazardous Locations

for Electrical Installations in Chemical Process Areas

NFPA 496, Standard for Purged and Pressurized Enclosures for Electrical Equipment

Installation in Classified Locations

NFPA 30A, Code for Motor Fuel Dispensing Facilities and Repair

Garages, 8.3

Emergency Electrical Disconnects

NFPA 30A, Code for Motor Fuel Dispensing Facilities and Repair

Garages, 8.4

Specific Requirements for Marine Fuel Facilities

NFPA 30A, Code for Motor Fuel Dispensing Facilities and Repair Garages, 8.5

\section{STORAGE OF LIQUIDS}

Scope

NFPA 30A, Code for Motor Fuel Dispensing Facilities and Repair Garages, 4.1

NFPA 30, Flammable and Combustible Liquids Code, 9.1

Definitions

NFPA 30, Flammable and Combustible Liquids Code, 9.2

General Requirements

NFPA 30A, Code for Motor Fuel Dispensing Facilities and Repair

Garages, 4.2 


\section{Codes and Standards Citations for Biodiesel Fuel}

NFPA 30, Flammable and Combustible Liquids Code, 9.3

Storage of Liquids

NFPA 30A, Code for Motor Fuel Dispensing Facilities and Repair

Garages, 4.3

UL 2245, Standard for Below-Grade Vaults for Flammable Liquid Storage Tanks

NFPA 91, Standard for Exhaust Systems for Air Conveying of Vapors, Gases, Mists, and Noncombustible Particulate Solids

UL 2080, Standard for Fire Resistant Tanks for Flammable and Combustible Liquids

UL 2085, Standards for Protected Aboveground Tanks for Flammable and Combustible Liquids

Safety Technology International (STI) Corrosion Control Standards Acceptable Containers

NFPA 30, Flammable and Combustible Liquids Code, 9.4

ASTM Standards for Containers

ANSI/UL Standards for Containers

US DOT 10CFR49

Flammable Liquids Storage Cabinets

NFPA 30, Flammable and Combustible Liquids Code, 9.5

NFPA 251, Standard Methods of Tests of Fire Resistance of Building Construction and Materials

NFPA 91, Standard for Exhaust Systems for Air Conveying of Vapors, Gases, Mists, and Noncombustible Particulate Solids

Maximum Allowable Quantities (MAQs) per Control Area

NFPA 30, Flammable and Combustible Liquids Code, 9.6

Control Areas

NFPA 30, Flammable and Combustible Liquids Code, 9.7

Classification of Occupancies That Exceed the MAQs of Liquids per Control Area

NFPA 30, Flammable and Combustible Liquids Code, 9.8

NFPA 5000, Building Construction and Safety Code

International Code Council (ICC) International Building Code

Construction Requirements

NFPA 30, Flammable and Combustible Liquids Code, 9.9

NFPA 251, Standard Methods of Tests of Fire Resistance of Building

Construction and Materials

NFPA 80, Standard for Fire Doors and Other Opening Protective's

Fire Protection

NFPA 30, Flammable and Combustible Liquids Code, 9.10

NFPA 10, Standard for Portable Fire Extinguishers

NFPA 13, Standard for the Installation of Sprinkler Systems

NFPA 14, Standard for the Installation of Standpipe and Hose

Systems 


\section{Codes and Standards Citations for Biodiesel Fuel}

Electrical Systems

NFPA 30, Flammable and Combustible Liquids Code, 9.12 Containment, Drainage, and Spill Control

NFPA 30, Flammable and Combustible Liquids Code, 9.13 Ventilation

NFPA 30, Flammable and Combustible Liquids Code, 9.14 Explosion Control

NFPA 30, Flammable and Combustible Liquids Code, 9.16

NFPA 68, Standard on Explosion Protection by Deflagration Venting Separation from Incompatible Materials

NFPA 30, Flammable and Combustible Liquids Code, 9.17 Dispensing, Handling, and Use of Liquids in Storage Areas

NFPA 30, Flammable and Combustible Liquids Code, 9.18 Outdoor Storage of Liquids

NFPA 30, Flammable and Combustible Liquids Code, 9.19

\section{STORAGE OF LIQUIDS IN CONTAINERS - Industrial Occupancies}

Scope

NFPA 30, Flammable and Combustible Liquids Code, 11.1

Definitions

NFPA 30, Flammable and Combustible Liquids Code, 11.2

General Requirements

NFPA 30, Flammable and Combustible Liquids Code, 11.3

\section{STORAGE OF LIQUIDS IN CONTAINERS - Storage Occupancies}

Scope

NFPA 30, Flammable and Combustible Liquids Code, 12.1

Definitions

NFPA 30, Flammable and Combustible Liquids Code, 12.2 General Requirements

NFPA 30, Flammable and Combustible Liquids Code, 12.3

NFPA 13, Standard for the Installation of Sprinkler Systems

Maximum Allowable Quantities and Maximum Storage Heights

NFPA 30, Flammable and Combustible Liquids Code, 12.6 Control Areas

NFPA 30, Flammable and Combustible Liquids Code, 12.7 General Purpose Warehouse Storing Liquids in Quantities not exceeding MAQ

NFPA 30, Flammable and Combustible Liquids Code, 12.8 Construction Requirements

NFPA 30, Flammable and Combustible Liquids Code, 12.9

Fire Protection

NFPA 30, Flammable and Combustible Liquids Code, 12.10 Emergency Control Systems

NFPA 30, Flammable and Combustible Liquids Code, 12.11 


\section{Codes and Standards Citations for Biodiesel Fuel}

Electrical Systems

NFPA 30, Flammable and Combustible Liquids Code, 12.12 Containment, Drainage, and Spill Control

NFPA 30, Flammable and Combustible Liquids Code, 12.13 Ventilation

NFPA 30, Flammable and Combustible Liquids Code, 12.14 Exhausted Enclosures

NFPA 30, Flammable and Combustible Liquids Code, 12.15 Explosion Control

NFPA 30, Flammable and Combustible Liquids Code, 12.16 Separation from Incompatible Materials

NFPA 30, Flammable and Combustible Liquids Code, 12.17 Dispensing, Handling, and Use of Liquids in Storage Occupancies

NFPA 30, Flammable and Combustible Liquids Code, 12.17 Outdoor Storage of Liquids

NFPA 30, Flammable and Combustible Liquids Code, 12.19

\section{STORAGE OF LIQUIDS IN CONTAINERS - Detached, Unprotected Buildings}

NFPA 30, Flammable and Combustible Liquids Code, 13 Scope

NFPA 30, Flammable and Combustible Liquids Code, 13.1

\section{Definitions}

NFPA 30, Flammable and Combustible Liquids Code, 13.2 General Requirements

NFPA 30, Flammable and Combustible Liquids Code, 13.3

NFPA 13, Standard for the Installation of Sprinkler Systems Maximum Allowable Quantities and Maximum Storage Heights

NFPA 30, Flammable and Combustible Liquids Code, 13.6 Control Areas

NFPA 30, Flammable and Combustible Liquids Code, 13.7 Construction Requirements

NFPA 30, Flammable and Combustible Liquids Code, 13.9 Fire Protection

NFPA 30, Flammable and Combustible Liquids Code, 13.1 Emergency Control Systems

NFPA 30, Flammable and Combustible Liquids Code, 13.11 Electrical Systems

NFPA 30, Flammable and Combustible Liquids Code, 13.12 Containment, Drainage, and Spill Control

NFPA 30, Flammable and Combustible Liquids Code, 13.13 Ventilation

NFPA 30, Flammable and Combustible Liquids Code, 13.14 


\section{Codes and Standards Citations for Biodiesel Fuel}

Exhausted Enclosures

NFPA 30, Flammable and Combustible Liquids Code, 13.15

Explosion Control

NFPA 30, Flammable and Combustible Liquids Code, 13.16 Separation from Incompatible Materials

NFPA 30, Flammable and Combustible Liquids Code, 13.17 Dispensing, Handling, and Use of Liquids in Detached, Unprotected Buildings

NFPA 30, Flammable and Combustible Liquids Code, 13.18 Outdoor Storage of Liquids

NFPA 30, Flammable and Combustible Liquids Code, 13.19

\section{OUTDOOR STORAGE}

NFPA 30, Flammable and Combustible Liquids Code, 15 Scope

NFPA 30, Flammable and Combustible Liquids Code, 15.1 Definitions

NFPA 30, Flammable and Combustible Liquids Code, 15.2 General Requirements

NFPA 30, Flammable and Combustible Liquids Code, 15.3 Outdoor Storage Adjacent to a Building

NFPA 30, Flammable and Combustible Liquids Code, 15.4

\section{AUTOMATIC FIRE PROTECTION FOR INSIDE LIQUID STORAGE AREAS}

Scope

NFPA 30, Flammable and Combustible Liquids Code, 16.1

\section{Definitions}

NFPA 30, Flammable and Combustible Liquids Code, 16.2 General Requirements

NFPA 30, Flammable and Combustible Liquids Code, 16.3

Automatic Sprinkler and Foam-Water Sprinkler Fire Protection Systems

NFPA 30, Flammable and Combustible Liquids Code, 16.4

NFPA 16, Standard for the Installation of Foam-Water Sprinkler and Foam-Water Spray Systems

NFPA 25, Standard for the Inspection, Testing, and Maintenance of

Water-Based Fire Protection Systems

Fire Protection System Design Criteria

NFPA 30, Flammable and Combustible Liquids Code, 16.5

NFPA 13, Standard for the Installation of Sprinkler Systems

NFPA 16, Standard for the Installation of Foam-Water Sprinkler and Foam-Water Spray Systems

UL 2368, Standard for Fire Exposure Testing of Intermediate Bulk Containers for Flammable and Combustible Liquids 


\section{Codes and Standards Citations for Biodiesel Fuel}

Fire Protection System Design Schemes

NFPA 30, Flammable and Combustible Liquids Code, 16.6

NFPA 13, Standard for the Installation of Sprinkler Systems Water Supply

NFPA 30, Flammable and Combustible Liquids Code, 16.7 Containment, Drainage, and Spill Control

NFPA 30, Flammable and Combustible Liquids Code, 16.8

NFPA 15, Standard for Water Spray Fixed Systems for Fire Protection

Other Automatic Fire Protection Systems

NFPA 30, Flammable and Combustible Liquids Code, 16.9

\section{STORAGE OF LIQUIDS IN TANKS - Requirements for all Tanks}

Scope

NFPA 30, Flammable and Combustible Liquids Code, 21.1

Definitions

NFPA 30, Flammable and Combustible Liquids Code, 21.2

General Requirements

NFPA 30, Flammable and Combustible Liquids Code, 21.3

Design and Construction of Storage Tanks

NFPA 30, Flammable and Combustible Liquids Code, 21.4

API Tank Specifications

UL Tank Standards

ANSI Tank Standards

ASME Code for Unfired Pressure Vessels

ASME Boiler and Pressure Vessel Code

API Standard 2000, Venting Atmospheric and Low-Pressure Storage

Tanks

NFPA 69, Standard on Explosion Prevention Systems

NFPA 77, Recommended Practice on Static Electricity

Testing Requirements for Tanks

NFPA 30, Flammable and Combustible Liquids Code, 21.5

API 653, Tank Inspection, Repair, Alteration, and Reconstruction

Fire Prevention and Control

NFPA 30, Flammable and Combustible Liquids Code, 21.6

NFPA 25, Standard for the Inspection, Testing, and Maintenance of

Water-Based Fire Protection Systems

Operation of Storage Tanks

NFPA 30, Flammable and Combustible Liquids Code, 21.7

API 2350, Overfill Protection for Storage Tanks in Petroleum Facilities

NFPA 704, Standard System for the Identification of the Hazards of

Materials for Emergency Response

NFPA 326, Standard for the Safeguarding of Tanks and Containers

for Entry, Cleaning, or Repair 


\section{Codes and Standards Citations for Biodiesel Fuel}

API Tank Cleaning Specifications

NFPA 329, Recommended Practice for Handling Releases of

Flammable and Combustible Liquids and Gases

Inspection and Maintenance of Storage Tanks and Storage Tank Appurtenances

NFPA 30, Flammable and Combustible Liquids Code, 21.8

API 653, Tank Inspection, Repair, Alteration, and Reconstruction

API 2350, Overfill Protection for Storage Tanks in Petroleum Facilities

API 12R1, Setting, Maintenance, Inspection, Operation, and Repair of

Tanks in Production Service

STI SP001, Standard for Inspection of Aboveground Storage Tanks

\section{STORAGE OF LIQUIDS IN TANKS - Aboveground Storage Tanks}

Scope

NFPA 30, Flammable and Combustible Liquids Code, 22.1

Definitions

NFPA 30, Flammable and Combustible Liquids Code, 22.2

Location of Aboveground Storage Tanks

NFPA 30, Flammable and Combustible Liquids Code, 22.4

Petroleum Equipment Institute (PEI) RP200, Recommended

Practices for Installation of Aboveground Storage Systems for

Motor Vehicle Fueling

Installation of Aboveground Storage Tanks

NFPA 30, Flammable and Combustible Liquids Code, 22.5

API 650, Welded Steel Tanks for Oil Storage

Vent Piping for Aboveground Tanks

NFPA 30, Flammable and Combustible Liquids Code, 22.6

Emergency Relief Venting for Fire Exposure for Aboveground Storage Tanks

NFPA 30, Flammable and Combustible Liquids Code, 22.7

Fire Protection for Aboveground Storage Tanks

NFPA 30, Flammable and Combustible Liquids Code, 22.8

NFPA 11, 15, and 69

UL 2080, Standard for Fire Resistant Tanks for Flammable and

Combustible Liquids

Additional Requirements for Fire-Resistant Aboveground Storage Tanks

NFPA 30, Flammable and Combustible Liquids Code, 22.9

Additional Requirements for Protected Aboveground Storage Tanks

NFPA 30, Flammable and Combustible Liquids Code, 22.10

UL 2085, Standards for Protected Aboveground Tanks for Flammable and Combustible Liquids

Control of Spills from Aboveground Storage Tanks

NFPA 30, Flammable and Combustible Liquids Code, 22.11

Equipment, Piping, and Fire Protection Systems in Remote Impoundment Areas and Diked Areas

NFPA 30, Flammable and Combustible Liquids Code, 22.12 


\section{Codes and Standards Citations for Biodiesel Fuel}

Tank Openings Other than Vents

NFPA 30, Flammable and Combustible Liquids Code, 22.13

Aboveground Storage Tanks Located in Areas Subject to Flooding

NFPA 30, Flammable and Combustible Liquids Code, 22.14

Collision Protection for Aboveground Storage Tanks

NFPA 30, Flammable and Combustible Liquids Code, 22.15

Installation Instructions for Aboveground Storage Tanks

NFPA 30, Flammable and Combustible Liquids Code, 22.16

Inspection and Maintenance of Aboveground Storage Tanks

NFPA 30, Flammable and Combustible Liquids Code, 22.17

API 653, Tank Inspection, Repair, Alteration, and Reconstruction

STI SP001, Standard for Inspection of Aboveground Storage Tanks

\section{STORAGE OF LIQUIDS IN TANKS - Underground Tanks}

Scope

NFPA 30, Flammable and Combustible Liquids Code, 23.1

Definitions

NFPA 30, Flammable and Combustible Liquids Code, 23.2

General Requirements

NFPA 30, Flammable and Combustible Liquids Code, 23.3

API, Underwriters' Laboratories of Canada (ULC), STI, National

Association of Corrosion Engineers (NACE), and UL Corrosion

Protection Standards

UL, STI and API Underground Tank Specifications

Location of Underground Storage Tanks

NFPA 30, Flammable and Combustible Liquids Code, 23.4

Installation of Underground Storage Tanks

NFPA 30, Flammable and Combustible Liquids Code, 23.5

Normal Venting for Underground Storage Tanks

NFPA 30, Flammable and Combustible Liquids Code, 23.6

Control of Spills from Underground Storage Tanks

NFPA 30, Flammable and Combustible Liquids Code, 23.11

Tank Openings Other than Vents

NFPA 30, Flammable and Combustible Liquids Code, 23.13

Underground Storage Tanks Located in Areas Subject to Flooding

NFPA 30, Flammable and Combustible Liquids Code, 23.14

Installation Instructions for Underground Storage Tanks

NFPA 30, Flammable and Combustible Liquids Code, 23.16

Inspection and Maintenance of Underground Storage Tanks

NFPA 30, Flammable and Combustible Liquids Code, 23.17

\section{STORAGE TANK BUILDINGS}

Scope

NFPA 30, Flammable and Combustible Liquids Code, 24.1 


\section{Codes and Standards Citations for Biodiesel Fuel}

Definitions

NFPA 30, Flammable and Combustible Liquids Code, 24.2

General Requirements

NFPA 30, Flammable and Combustible Liquids Code, 24.3

Location of Storage Tank Buildings

NFPA 30, Flammable and Combustible Liquids Code, 24.4

NFPA 68, Standard on Explosion Protection by Deflagration Venting

Construction of Storage Tank Buildings

NFPA 30, Flammable and Combustible Liquids Code, 24.5

NFPA 220, Standard on Types of Building Construction

NFPA 101, Life Safety Code

Fire Protection for Storage Tank Buildings

NFPA 30, Flammable and Combustible Liquids Code, 24.6

NFPA 10, Standard for Portable Fire Extinguishers

NFPA 13, Standard for the Installation of Sprinkler Systems

NFPA 14, Standard for the Installation of Standpipe and Hose

Systems

NFPA 24, Standard for the Installation of Private Fire Service Mains and Their Appurtenances

NFPA 11, 12, 12A, 15, 16, 17, and 25

Emergency Control Systems for Storage Tank Buildings

NFPA 30, Flammable and Combustible Liquids Code, 24.7

Electrical Systems for Storage Tank Buildings

NFPA 30, Flammable and Combustible Liquids Code, 24.8

Containment, Drainage, and Spill Control from Storage Tank Buildings

NFPA 30, Flammable and Combustible Liquids Code, 24.9

Ventilation for Storage Tank Buildings

NFPA 30, Flammable and Combustible Liquids Code, 24.10

NFPA 91, Standard for Exhaust Systems for Air Conveying of Vapors,

Gases, Mists, and Noncombustible Particulate Solids

NFPA 90A, Standard for the Installation of Air-Conditioning and

Ventilation Systems

Explosion Control

NFPA 30, Flammable and Combustible Liquids Code, 24.12

NFPA 13, Standard for the Installation of Sprinkler Systems

NFPA 15, Standard for Water Spray Fixed Systems for Fire

Protection

Vents for Tanks Inside Storage Tank Buildings

NFPA 30, Flammable and Combustible Liquids Code, 24.13

Tank Openings Other than Vents for Tanks Inside Storage Tank Buildings

NFPA 30, Flammable and Combustible Liquids Code, 24.14

Detection and Alarm Systems for Storage Tank Buildings

NFPA 30, Flammable and Combustible Liquids Code, 24.15 


\section{Codes and Standards Citations for Biodiesel Fuel}

Inspection of Maintenance for Storage Tank Buildings

NFPA 30, Flammable and Combustible Liquids Code, 24.16

\section{STORAGE TANK VAULTS}

Scope

NFPA 30, Flammable and Combustible Liquids Code, 25.1

Definitions

NFPA 30, Flammable and Combustible Liquids Code, 25.2

General Requirements

NFPA 30, Flammable and Combustible Liquids Code, 25.3

ANSI/UL 2245, Standard for Below-Grade Vaults for Flammable

Liquid Storage Tanks

Location of Storage Tank Vaults

NFPA 30, Flammable and Combustible Liquids Code, 25.4

Construction and Installation of Storage Tank Vaults

NFPA 30, Flammable and Combustible Liquids Code, 25.5

Fire Protection for Storage Tank Vaults

NFPA 30, Flammable and Combustible Liquids Code, 25.6 Emergency Controls For Storage Tank Vaults

NFPA 30, Flammable and Combustible Liquids Code, 25.7 Electrical Systems for Storage Tank Vaults

NFPA 30, Flammable and Combustible Liquids Code, 25.8

Containment, Drainage, and Spill Control for Storage Tank Vaults

NFPA 30, Flammable and Combustible Liquids Code, 25.9

Ventilation Systems for Storage Tank Vaults

NFPA 30, Flammable and Combustible Liquids Code, 25.10

NFPA 91, Standard for Exhaust Systems for Air Conveying of Vapors,

Gases, Mists, and Noncombustible Particulate Solids

Explosion Control

NFPA 30, Flammable and Combustible Liquids Code, 25.12

Vents for Tanks Inside Storage Tank Vaults

NFPA 30, Flammable and Combustible Liquids Code, 25.13

Tank Openings Other than Vents for Tanks Inside Storage Tank Vaults

NFPA 30, Flammable and Combustible Liquids Code, 25.14

Detection and Alarm Systems for Storage Tank Vaults

NFPA 30, Flammable and Combustible Liquids Code, 25.15

Inspection and Maintenance of Storage Tank Vaults and Equipment

NFPA 30, Flammable and Combustible Liquids Code, 25.16

\section{PROCESSING FACILITIES}

Scope

NFPA 30, Flammable and Combustible Liquids Code, 17.1

Definitions

NFPA 30, Flammable and Combustible Liquids Code, 17.2 


\section{Codes and Standards Citations for Biodiesel Fuel}

General Requirements

NFPA 30, Flammable and Combustible Liquids Code, 17.3

Location of Process Vessels and Equipment

NFPA 30, Flammable and Combustible Liquids Code, 17.4 Accessibility

NFPA 30, Flammable and Combustible Liquids Code, 17.5

Construction Requirements

NFPA 30, Flammable and Combustible Liquids Code, 17.6

NFPA 5000, Building Construction and Safety Code

ICC International Building Code

NFPA 15, Standard for Water Spray Fixed Systems for Fire

Protection

API 2218, Fireproofing Practices in Petroleum and Petrochemical

Processing Plants

NFPA 204, Standard for Smoke and Heat Venting

NFPA 101, Life Safety Code

NFPA 68, Standard on Explosion Protection by Deflagration Venting

Containment, Drainage, and Spill Control

NFPA 30, Flammable and Combustible Liquids Code, 17.10

NFPA 15, Standard for Water Spray Fixed Systems for Fire

Protection

Ventilation

NFPA 30, Flammable and Combustible Liquids Code, 17.11

NFPA 91, Standard for Exhaust Systems for Air Conveying of Vapors,

Gases, Mists, and Noncombustible Particulate Solids

NFPA 90A, Standard for the Installation of Air-Conditioning and

Ventilation Systems

Process Equipment and Vessels

NFPA 30, Flammable and Combustible Liquids Code, 17.14

NFPA 68, Standard on Explosion Protection by Deflagration Venting Management of Operations Hazards

NFPA 30, Flammable and Combustible Liquids Code, 17.15

\section{DISPENSING, HANDLING, TRANSFER, AND USE OF LIQUIDS}

Scope

NFPA 30A, Code for Motor Fuel Dispensing and Repair Garages, 6.1

NFPA 30, Flammable and Combustible Liquids Code, 18.1

Definitions

NFPA 30, Flammable and Combustible Liquids Code, 18.2

General Requirements

NFPA 30A, Code for Motor Fuel Dispensing and Repair Garages, 6.2

Requirements for Dispensing Devices

NFPA 30A, Code for Motor Fuel Dispensing and Repair Garages, 6.3 


\section{Codes and Standards Citations for Biodiesel Fuel}

Requirements for Remote/Submersible Pumps

NFPA 30A, Code for Motor Fuel Dispensing and Repair Garages, 6.4 Requirements for Dispensing Hose

NFPA 30A, Code for Motor Fuel Dispensing and Repair Garages, 6.5 Requirements for Fuel Delivery Nozzles

NFPA 30A, Code for Motor Fuel Dispensing and Repair Garages, 6.6

UL 842, Standard for Valves for Flammable Fluids

Emergency Electrical Disconnects

NFPA 30A, Code for Motor Fuel Dispensing and Repair Garages, 6.7 Vapor Recovery Systems

NFPA 30A, Code for Motor Fuel Dispensing and Repair Garages, 6.8 Dispensing, Handling, Transfer, and Use of Liquids

NFPA 30, Flammable and Combustible Liquids Code, 18.3 Incidental Operations

NFPA 30, Flammable and Combustible Liquids Code, 18.4

NFPA 91, Standard for Exhaust Systems for Air Conveying of Vapors,

Gases, Mists, and Noncombustible Particulate Solids

Ventilation for Dispensing Areas

NFPA 30, Flammable and Combustible Liquids Code, 18.5

NFPA 91, Standard for Exhaust Systems for Air Conveying of Vapors,

Gases, Mists, and Noncombustible Particulate Solids

Component Standards

ANSI/UL 25 Meters for Flammable and Combustible Liquids

ANSI/UL 79, Flammable and Combustible Liquid Pumps for dispensing

UL 87, Power-Operated Dispensing Devices for Petroleum Products

UL 330, Hose and Hose Assemblies for Dispensing Flammable Liquids

ANSI/UL 331, Strainers for Flammable Fluids and Anhydrous

Ammonia

UL 429, Electrical Valves, for use in control of dispensing equipment

ANSI/UL 567, Emergency Breakaway Fittings, Swivel Connectors and

Pipe-Connection Fittings for Petroleum Products and Liquefied

Petroleum Gas

ANSI/UL 842, Valves for Flammable Fluids

UL 860, Pipe Unions for Flammable and Combustible Fluids and Fire-

Protection Service

\section{OPERATIONAL REQUIREMENTS}

Scope

NFPA 30A, Code for Motor Fuel Dispensing and Repair Garages, 9.1

Basic Requirements

NFPA 30A, Code for Motor Fuel Dispensing and Repair Garages, 9.2 


\section{Codes and Standards Citations for Biodiesel Fuel}

NFPA 385, Standard for Tank Vehicles for Flammable and Combustible Liquids

NFPA 10, Standard for Portable Fire Extinguishers

Operating Requirements for Full-Service Motor Fuel Dispensing Facilities

NFPA 30A, Code for Motor Fuel Dispensing and Repair Garages, 9.3

Operating Requirements for Attended Self-Service Motor Fuel Dispensing Facilities

NFPA 30A, Code for Motor Fuel Dispensing and Repair Garages, 9.4 Operating Requirement for Unattended Self-Service Motor Fuel Dispensing Facilities

NFPA 30A, Code for Motor Fuel Dispensing and Repair Garages, 9.5 Refueling from Tank Vehicles

NFPA 30A, Code for Motor Fuel Dispensing and Repair Garages, 9.6

NFPA 385, Standard for Tank Vehicles for Flammable and Combustible Liquids

\section{Repair Areas}

NFPA 30A, Code for Motor Fuel Dispensing and Repair Garages, 9.7

NFPA 51B, Standard for Fire Prevention During Welding, Cutting, and Other Hot Work

NFPA 51, Standard for the Design and Installation of Oxygen-Fuel Gas Systems for Welding, Cutting, and Allied Processes

NFPA 33, Standards for Spray Applications Using Flammable or Combustible Materials

NFPA 326, Standard for the Safeguarding of Tanks and Containers for Entry, Cleaning, or Repair

NFPA 31, Standards for the Installation of Oil-Burning Equipment

NFPA 54, National Fuel Gas Code

NFPA 85, Boiler and Combustion Systems Hazards Code

NFPA 55, Compressed Gases and Cryogenic Fluids Code

\section{PIPING FOR LIQUIDS}

Scope

NFPA 30A, Code for Motor Fuel Dispensing and Repair Garages, 5.1

NFPA 30, Flammable and Combustible Liquids Code, 27.1

Definitions

NFPA 30, Flammable and Combustible Liquids Code, 27.2

General Requirements for All Piping Systems

NFPA 30A, Code for Motor Fuel Dispensing and Repair Garages, 5.2

NFPA 30, Flammable and Combustible Liquids Code, 27.3

ASME B31, Code for Pressure Piping

API 607, Fire Test for Soft-Seated Quarter-Turn Valves

ASTM Piping Standards

Materials of Construction for Piping Systems

NFPA 30, Flammable and Combustible Liquids Code, 27.4 


\section{Codes and Standards Citations for Biodiesel Fuel}

Pipe Joints

NFPA 30, Flammable and Combustible Liquids Code, 27.5 Installation of Piping Systems

NFPA 30A, Code for Motor Fuel Dispensing and Repair Garages, 5.3

NFPA 30, Flammable and Combustible Liquids Code, 27.6

Testing of Piping Systems

NFPA 30A, Code for Motor Fuel Dispensing and Repair Garages, 5.4

NFPA 30, Flammable and Combustible Liquids Code, 27.7

Detector Maintenance

NFPA 30A, Code for Motor Fuel Dispensing and Repair Garages, 5.5 Vent Piping

NFPA 30A, Code for Motor Fuel Dispensing and Repair Garages, 5.6

NFPA 30, Flammable and Combustible Liquids Code, 27.8

Vapor Recovery Piping

NFPA 30A, Code for Motor Fuel Dispensing and Repair Garages, 5.7 Bonding and Grounding

NFPA 30, Flammable and Combustible Liquids Code, 27.9

Identification and Marking of Piping Systems

NFPA 30, Flammable and Combustible Liquids Code, 27.10

Removal From Service of Piping Systems

NFPA 30, Flammable and Combustible Liquids Code, 27.12

\section{VAPOR PROCESSING AND VAPOR RECOVERY SYSTEMS FOR LIQUID MOTOR FUELS}

Vapor Processing Systems

NFPA 30A, Code for Motor Fuel Dispensing and Repair Garages, 10.1

Vapor Recovery Systems

NFPA 30A, Code for Motor Fuel Dispensing and Repair Garages, 10.2

\section{FARMS AND REMOTE SITES}

Scope

NFPA 30A, Code for Motor Fuel Dispensing and Repair Garages,

13.1

NFPA 30, Flammable and Combustible Liquids Code

Approved Storage

NFPA 30A, Code for Motor Fuel Dispensing and Repair Garages,

13.2

NFPA 30, Flammable and Combustible Liquids Code

Marking of Tanks and Containers

NFPA 30A, Code for Motor Fuel Dispensing and Repair Garages, 13.3 


\section{Codes and Standards Citations for Biodiesel Fuel}

Fire Prevention and Control

NFPA 30A, Code for Motor Fuel Dispensing and Repair Garages, 13.4

\section{VEHICLE}

Fuels

- ASTM D6751-08, Standard Specification for Biodiesel Fuel Blend Stock (B100) for Middle Distillate Fuels

- ASTM D975-09a, Standard Specification for Diesel Fuel Oils

- ASTM D7467-08, Standard Specification for Diesel Fuel Oil, Biodiesel Blend (B6 to B20)

Systems

SAE J1681, New Biodiesel Task Force formed to study and revise

"Gasoline, Alcohol, Diesel Fuel Surrogates for Material Testing"

SAE J30, Fuel and Oil Hoses

SAE J35, Diesel Smoke Measurement Procedure

SAE J177, Measurement of Carbon Dioxide, Carbon Monoxide, and

Oxides of Nitrogen in Diesel Exhaust

SAE J215, Continuous Hydrocarbon Analysis of Diesel Emissions

SAE J254, Instrumentation and Techniques for Exhaust Gas

Emissions Measurement

SAE J255, Diesel Engine Smoke Measurement

SAE J285, Dispenser Nozzle Spouts for Liquid Fuels intended for Use with Spark Ignition and Compression Ignition Engines

SAE J313, Diesel Fuels

SAE J607, Small Spark Ignition Engine Test Code

SAE J905, Fuel Filter Test Methods

SAE J1003, Diesel Engine Emission

Measurement Procedure

SAE J1082, Fuel Economy Measurement-Road Test Procedure

SAE J1088, Test Procedure for the Measurement of Exhaust

Emissions from Small Utility Engines

SAE J1094, Constant Volume Sampler System for Exhaust

Emissions Measurement

SAE J1130, Determination of Emission from Gas Turbine Powered light Duty Surface Vehicles

SAE J1243, Diesel Emissions Production Audit Test Procedure

SAE J1256, Fuel Economy Measurement- Road Test Procedure-

Cold Start and Warm-up Fuel Economy

SAE J1297, Alternative Automotive Fuels

SAE J1312, Procedure for Mapping Engine Performance- Diesel and

Spark Ignition Engines

SAE J1349, Engine Power Test Code- Spark ignition and Diesel 


\section{Codes and Standards Citations for Biodiesel Fuel}

SAE J1350, Selection and Application Guidelines for Diesel, Gasoline, and Propane Fired Liquid Cooled Engine Pre-Heaters SAE J1376, Fuel Economy Measurement Test (Engineering Type) for Trucks and Buses

SAE J1498, Heating Values of Fuels

SAE J1829, Stoichiometric Air/Fuel Ratios of Automotive Fuels

SAE J2785, Standardization of Color and Verbiage for Fuel Inlet Closures

SAE J2793, Fuel Dispensing Filter Test Methods- Draft document 


\section{Gaps in Codes and Standards}

\section{Infrastructure}

A major barrier to more widespread use of Biodiesel as a motor fuel is the lack of infrastructure for fuel storage, blending, and dispensing. Infrastructure component compatibility issues may not be technically understood by AHJs, making the permitting and installation of associated fueling facilities a potential issue. For example, the California Water Resources Board has issued guidance to AHJs citing concerns with the lack of UL Listing of underground storage tanks used for Biodiesel with blends over 5 percent [25]. On the other hand, NFPA 30 cites UL Listings for underground storage tanks for flammable and combustible liquids. This issue creates a gap between an approved standard for components and AHJs and other regulatory bodies with concerns relative to the standards and cited listed components and their compatibility with Biodiesel.

The key to addressing the gap between the NFPA standards listing and use of storage vessels for biodiesel is addressing biodiesel compatibility with listed storage vessels. A likely solution is providing research data or supporting current research projects. Furthermore, participation on the NFPA 30 and 30A technical committees responsible for writing the standards would help resolve the vessel compatibility issue.

Furthermore, components such as dispensing hoses and nozzles, etc. may entirely lack a UL Listing for Biodiesel in blends greater than 5 percent. The solution cited above would facilitate development of Biodiesel component standards.

The delivery and use mechanism most often used for Biodiesel is located at fleet customer facilities and heavy volume facilities such as truck stops, etc. B5 is the most common Biodiesel product in use as a blend with petroleum diesel. The use of blends as high as B20 and higher could benefit from the transportation of the fuel via pipeline. However, many existing pipelines are multi-use and the cross-contamination of fuels must be addressed. For example, to use a multi-use pipeline for Biodiesel, a jet engine must be evaluated and proved to run its useful life on jet fuel that has low (100 ppm) biodiesel contamination without operating issues.

Becoming more active and involved in the testing required for multi-use pipelines, and engaging the organizations who regulate them could initiate a solution to the use of existing multi-use pipelines for Biodiesel.

\section{Fuel Composition}

Another barrier to more widespread use of Biodiesel as a motor fuel is the compatibility of Biodiesel blends greater than 5 percent with some engines manufactured after 2007. In order to meet particulate emission standards implemented by the EPA, manufactures have installed particulate filters in the exhaust system on vehicles. In the process of reducing particulate emissions, particulates build-up and become trapped within the filter. The trapped particulates must be removed to ensure continued efficient performance of the filter. Two current methods to remove the build-up are used. Both involve the elimination of particulates by combustion. One method to remove particulates from filters is the direct injection of vaporized fuel into the exhaust stream which is then burned with the 
particulates over a catalyst. This method requires the addition of an injection system. The more popular and cost effective method is injection of vaporized fuel into the cylinder via the existing fuel injection system, but during the exhaust phase of the cylinder which burns in the exhaust system. However, Biodiesel may not be compatible with the latter process in some engines due to the transfer of some of the lower volatility biodiesel to the lubrication system on the vehicle, where it accumulates.

Emissions are always a concern when considering the use of a fuel other than the fuel the manufacturer intended, including the conversion from diesel to biodiesel operation. The use of Biodiesel does not result in a significantly different emission signature in most cases. The case can be made for either a slight increase or decrease in nitrogen oxide emissions as a result of the use of Biodiesel. In either case, current manufactured lightduty vehicles and heavy-duty vehicles manufactured beginning in 2010 are required to have nitrogen oxide control catalysts in the exhaust systems. A compatibility concern exists with Biodiesel fuel quality relative to the nitrogen oxide reduction catalyst.

Likely solutions for this gap are providing research data demonstrating that these concerns are real problems, and developing or revising Biodiesel fuel quality standards, if needed. Collaboration with efforts already underway in the areas of fuel composition, effects of fuel on lubrication systems, and emissions catalysts would be productive.

\section{Vehicle Fleet Size}

Another potential barrier to more widespread use of Biodiesel as a motor fuel is the lack of availability of diesel passenger vehicles in the United States. Diesel sedans are only moderately available in the United States, and only through a few foreign manufacturers. Wagon and sport utility type vehicles are more limited, although national manufacturers do produce heavy-duty diesel pickup trucks. The lack of diesel passenger vehicle availability for American consumers is not due to manufacturing limitations or capacity, but a matter of business policy by the manufacturers. The sale of these vehicles is more profitable in European and other markets because, in part, of the relative value of the American dollar [26]. Exploration of methods to increase the number of diesel passenger vehicles available to consumers in the United States should be considered.

\section{Summary}

Table 10 presents a summary of the identified Code and Standards Gaps for the expanded use of Biodiesel as an alternative fuel. Also presented in the table is the impacted document and proposed means to address the gap. 
Table 10: Codes and Standards Gaps for Biodiesel

\begin{tabular}{|c|c|c|}
\hline Vehicle Codes and Standards Gap & $\begin{array}{l}\text { Documents } \\
\text { Impacted }\end{array}$ & Gap Resolution \\
\hline $\begin{array}{l}\text { Lack of data for existing Codes } \\
\text { and Standards applicability to } \\
\text { Biodiesel storage systems }\end{array}$ & $\begin{array}{l}\text { NFPA 30/30A } \\
\text { and associated } \\
\text { listing documents }\end{array}$ & $\begin{array}{l}\text { Provide data for the } \\
\text { compatibility of } \\
\text { Biodiesel with listed } \\
\text { storage systems }\end{array}$ \\
\hline Limited infrastructure & $\begin{array}{l}\text { NFPA 30/30A } \\
\text { and associated } \\
\text { listing documents }\end{array}$ & $\begin{array}{l}\text { Resolve compatibility } \\
\text { and production quality } \\
\text { issues }\end{array}$ \\
\hline $\begin{array}{l}\text { Incompatibility of multi-use } \\
\text { pipelines with biodiesel, especially } \\
\text { the contamination of other fuel } \\
\text { types by biodiesel }\end{array}$ & $\begin{array}{l}\text { DOT Pipeline } \\
\text { Regulations }\end{array}$ & $\begin{array}{l}\text { Provide data for the } \\
\text { compatibility of } \\
\text { Biodiesel } \\
\text { contamination with } \\
\text { other fuel systems }\end{array}$ \\
\hline $\begin{array}{l}\text { Incompatibility of biodiesel with } \\
\text { clean diesel engines } \\
\text { (contamination of the motor } \\
\text { lubrication system) }\end{array}$ & $\begin{array}{l}\text { SAE engine } \\
\text { performance } \\
\text { documents }\end{array}$ & $\begin{array}{l}\text { Provide data for the } \\
\text { compatibility of } \\
\text { Biodiesel with } \\
\text { traditional diesel fuel } \\
\text { systems }\end{array}$ \\
\hline $\begin{array}{l}\text { Compatibility with catalysts on } \\
\text { engine emission systems }\end{array}$ & $\begin{array}{l}\text { SAE engine } \\
\text { performance } \\
\text { documents }\end{array}$ & $\begin{array}{l}\text { Provide data for the } \\
\text { compatibility of } \\
\text { Biodiesel with diesel } \\
\text { engine emission } \\
\text { systems }\end{array}$ \\
\hline Limited OEM vehicle availability & $\mathrm{N} / \mathrm{A}$ & $\begin{array}{l}\text { Explore government } \\
\text { assistance options for } \\
\text { diesel vehicle } \\
\text { availability }\end{array}$ \\
\hline
\end{tabular}




\section{ETHANOL}




\section{Ethanol $^{5}$}

\section{Background}

Flexible fuel vehicles (FFVs) are capable of operating on gasoline, E85 (85 percent ethanol, 15 percent gasoline), or any mixture of both. Although approximately 8 million FFVs drive on American roads today, many FFV owners are not aware that their vehicle has this capability.

The following link provides information to the public regarding OEM new FFVs (gasoline and E85), fueling infrastructure, costs, fuel prices, a list of existing E85 fueling facilities, and other related information from the Alternative Fuels and Advanced Vehicles Data Center [27]:

http://www.afdc.energy.gov/afdc/ethanol/ethanol_locations.html.

\section{Codes and Standards Structure}

The codes and standards structure for Ethanol is similar to that of Biodiesel, as both are treated as flammable liquids. NFPA 30, The Flammable and Combustible Liquids Code, and NFPA 30A, The Code for Motor Fuel Dispensing Facilities and Repair Garages, are both used throughout the United States and directly adopted as regulations by most states. These documents set requirements for storage, dispensing, and onboard vehicle systems for Ethanol. In addition, the IBC is generally adopted and used as the building code in most jurisdictions and also applies to infrastructure. Table 11 lists code citations from NFPA 30 and 30A as well as the documents referenced within them.

Table 11: Codes and Standards for Ethanol Fuel

\section{Codes and Standards Citations for Ethanol Fuel}

\section{DEFINITION AND CLASSIFICATION OF LIQUIDS}

Scope

NFPA 30, Flammable and Combustible Liquids Code, 4.1

Definitions

NFPA 30, Flammable and Combustible Liquids Code, 4.2

ASTM Standard Test Methods

Classification of Liquids

NFPA 30, Flammable and Combustible Liquids Code, 4.3

ASTM Standard Test Methods

Determination of Flash Point

NFPA 30, Flammable and Combustible Liquids Code, 4.4

ASTM Standard Test Methods

Relationship to Other Classification Systems

NFPA 30, Flammable and Combustible Liquids Code, 4.5

\footnotetext{
${ }^{5}$ Expert discussion on the use of Ethanol as an alternative fuel, included herein, was provided by Robert McCormick.
} 


\section{Codes and Standards Citations for Ethanol Fuel}

\section{FIRE PREVENTION AND FIRE RISK CONTROL}

Scope

NFPA 30, Flammable and Combustible Liquids Code, 6.1

\section{Definitions}

NFPA 30, Flammable and Combustible Liquids Code, 6.2 Management of Fire and Explosion Hazards

NFPA 30, Flammable and Combustible Liquids Code, 6.3

NFPA 69, Standard on Explosion Prevention Systems

NFPA 68, Standard on Explosion Protection by Deflagration Venting Hazards Analysis

NFPA 30, Flammable and Combustible Liquids Code, 6.4 Control of Ignition Sources

NFPA 30, Flammable and Combustible Liquids Code, 6.5

NFPA 51B, Standard for Fire Prevention During Welding, Cutting, and Other Hot Work

NFPA 77, Recommended Practice on Static Electricity

Detection and Alarm Systems

NFPA 30, Flammable and Combustible Liquids Code, 6.6

NFPA 72, National Fire Alarm Code

Fire Protection and Suppression Systems

NFPA 30, Flammable and Combustible Liquids Code, 6.7

NFPA 24, Standard for the Installation of Private Fire Service Mains and Their Appurtenances

NFPA 13, Standard for the Installation of Sprinkler Systems

NFPA 10, 11, 12, 12A, 14, 15, 16, 17, 2001

Emergency Planning and Training

NFPA 30, Flammable and Combustible Liquids Code, 6.8 Inspection and Maintenance

NFPA 30, Flammable and Combustible Liquids Code, 6.9

NFPA 25, Standard for the Inspection, Testing, and Maintenance of

Water-Based Fire Protection Systems

Management of Security

NFPA 30, Flammable and Combustible Liquids Code, 6.10

\section{BUILDING CONSTRUCTION REQUIREMENTS}

Scope

NFPA 30A, Code for Motor Fuel Dispensing Facilities and Repair Garages, 7.1

General Requirements

NFPA 30A, Code for Motor Fuel Dispensing Facilities and Repair

Garages, 7.2

Motor Fuel Dispensing Facilities

NFPA 30A, Code for Motor Fuel Dispensing Facilities and Repair Garages, 7.3 


\section{Codes and Standards Citations for Ethanol Fuel}

NFPA 101, Life Safety Code

NFPA 220, Standard on Types of Building Construction

NFPA 80, Standard for Fire Doors and Other Opening Protectives

NFPA 91, Standard for Exhaust Systems for Air Conveying of Vapors,

Gases, Mists, and Noncombustible Particulate Solids

Repair Garages

NFPA 30A, Code for Motor Fuel Dispensing Facilities and Repair

Garages, 7.4

NFPA 101, Life Safety Code

NFPA 13, Standard for the Installation of Sprinkler Systems

NFPA 90A, Standard for the Installation of Air-Conditioning and

Ventilation Systems

Heating, Ventilation, and Air-Conditioning

NFPA 30A, Code for Motor Fuel Dispensing Facilities and Repair Garages, 7.5

Heat-Producing Appliances

NFPA 30A, Code for Motor Fuel Dispensing Facilities and Repair Garages, 7.6

Dynamic Automotive Emissions Testing Equipment

NFPA 30A, Code for Motor Fuel Dispensing Facilities and Repair Garages, 7.7

\section{ELECTRICAL SYSTEMS}

Scope

NFPA 30A, Code for Motor Fuel Dispensing Facilities and Repair Garages, 8.1

NFPA 30, Flammable and Combustible Liquids Code, 7.1 Definitions

NFPA 30, Flammable and Combustible Liquids Code, 7.2 General Requirements

NFPA 30A, Code for Motor Fuel Dispensing Facilities and Repair Garages, 8.2

NFPA 30, Flammable and Combustible Liquids Code, 7.3

NFPA 70, National Electric Code

NFPA 497, Recommended Practice for the Classification of

Flammable Liquids, Gases, or Vapors and of Hazardous Locations for Electrical Installations in Chemical Process Areas

NFPA 496, Standard for Purged and Pressurized Enclosures for Electrical Equipment

Installation in Classified Locations

NFPA 30A, Code for Motor Fuel Dispensing Facilities and Repair Garages, 8.3 


\section{Codes and Standards Citations for Ethanol Fuel}

Emergency Electrical Disconnects

NFPA 30A, Code for Motor Fuel Dispensing Facilities and Repair Garages, 8.4

Specific Requirements for Marine Fuel Facilities

NFPA 30A, Code for Motor Fuel Dispensing Facilities and Repair Garages, 8.5

\section{STORAGE OF LIQUIDS}

Scope

NFPA 30A, Code for Motor Fuel Dispensing Facilities and Repair Garages, 4.1

NFPA 30, Flammable and Combustible Liquids Code, 9.1

\section{Definitions}

NFPA 30, Flammable and Combustible Liquids Code, 9.2

General Requirements

NFPA 30A, Code for Motor Fuel Dispensing Facilities and Repair Garages, 4.2

NFPA 30, Flammable and Combustible Liquids Code, 9.3

Storage of Liquids

NFPA 30A, Code for Motor Fuel Dispensing Facilities and Repair Garages, 4.3

UL 2245, Standard for Below-Grade Vaults for Flammable Liquid Storage Tanks

NFPA 91, Standard for Exhaust Systems for Air Conveying of Vapors, Gases, Mists, and Noncombustible Particulate Solids

UL 2080, Standard for Fire Resistant Tanks for Flammable and Combustible Liquids

UL 2085, Standards for Protected Aboveground Tanks for Flammable and Combustible Liquids

STI Corrosion Control Standards

Acceptable Containers

NFPA 30, Flammable and Combustible Liquids Code, 9.4

ASTM Standards for Containers

ANSI/UL Standards for Containers

US DOT 10CFR49

Flammable Liquids Storage Cabinets

NFPA 30, Flammable and Combustible Liquids Code, 9.5

NFPA 251, Standard Methods of Tests of Fire Resistance of Building Construction and Materials

NFPA 91, Standard for Exhaust Systems for Air Conveying of Vapors, Gases, Mists, and Noncombustible Particulate Solids

Maximum Allowable Quantities (MAQs) per Control Area

NFPA 30, Flammable and Combustible Liquids Code, 9.6 


\section{Codes and Standards Citations for Ethanol Fuel}

Control Areas

NFPA 30, Flammable and Combustible Liquids Code, 9.7

Classification of Occupancies That Exceed the MAQs of Liquids per Control Area

NFPA 30, Flammable and Combustible Liquids Code, 9.8

NFPA 5000, Building Construction and Safety Code

ICC International Building Code

Construction Requirements

NFPA 30, Flammable and Combustible Liquids Code, 9.9

NFPA 251, Standard Methods of Tests of Fire Resistance of Building

Construction and Materials

NFPA 80, Standard for Fire Doors and Other Opening Protectives

Fire Protection

NFPA 30, Flammable and Combustible Liquids Code, 9.10

NFPA 10, Standard for Portable Fire Extinguishers

NFPA 13, Standard for the Installation of Sprinkler Systems

NFPA 14, Standard for the Installation of Standpipe and Hose

Systems

Electrical Systems

NFPA 30, Flammable and Combustible Liquids Code, 9.12 Containment, Drainage, and Spill Control

NFPA 30, Flammable and Combustible Liquids Code, 9.13 Ventilation

NFPA 30, Flammable and Combustible Liquids Code, 9.14 Explosion Control

NFPA 30, Flammable and Combustible Liquids Code, 9.16

NFPA 68, Standard on Explosion Protection by Deflagration Venting Separation from Incompatible Materials

NFPA 30, Flammable and Combustible Liquids Code, 9.17

Dispensing, Handling, and Use of Liquids in Storage Areas

NFPA 30, Flammable and Combustible Liquids Code, 9.18

Outdoor Storage of Liquids

NFPA 30, Flammable and Combustible Liquids Code, 9.19

\section{STORAGE OF LIQUIDS IN CONTAINERS - Industrial Occupancies}

Scope

NFPA 30, Flammable and Combustible Liquids Code, 11.1

Definitions

NFPA 30, Flammable and Combustible Liquids Code, 11.2 General Requirements

NFPA 30, Flammable and Combustible Liquids Code, 11.3 


\section{Codes and Standards Citations for Ethanol Fuel}

\section{STORAGE OF LIQUIDS IN CONTAINERS - Storage Occupancies}

Scope

NFPA 30, Flammable and Combustible Liquids Code, 12.1

\section{Definitions}

NFPA 30, Flammable and Combustible Liquids Code, 12.2 General Requirements

NFPA 30, Flammable and Combustible Liquids Code, 12.3

NFPA 13, Standard for the Installation of Sprinkler Systems Maximum Allowable Quantities and Maximum Storage Heights

NFPA 30, Flammable and Combustible Liquids Code, 12.6 Control Areas

NFPA 30, Flammable and Combustible Liquids Code, 12.7 General Purpose Warehouse Storing Liquids in Quantities not exceeding MAQ

NFPA 30, Flammable and Combustible Liquids Code, 12.8 Construction Requirements

NFPA 30, Flammable and Combustible Liquids Code, 12.9 Fire Protection

NFPA 30, Flammable and Combustible Liquids Code, 12.10 Emergency Control Systems

NFPA 30, Flammable and Combustible Liquids Code, 12.11 Electrical Systems

NFPA 30, Flammable and Combustible Liquids Code, 12.12 Containment, Drainage, and Spill Control

NFPA 30, Flammable and Combustible Liquids Code, 12.13 Ventilation

NFPA 30, Flammable and Combustible Liquids Code, 12.14 Exhausted Enclosures

NFPA 30, Flammable and Combustible Liquids Code, 12.15 Explosion Control

NFPA 30, Flammable and Combustible Liquids Code, 12.16 Separation from Incompatible Materials

NFPA 30, Flammable and Combustible Liquids Code, 12.17 Dispensing, Handling, and Use of Liquids in Storage Occupancies

NFPA 30, Flammable and Combustible Liquids Code, 12.18 Outdoor Storage of Liquids

NFPA 30, Flammable and Combustible Liquids Code, 12.19

\section{STORAGE OF LIQUIDS IN CONTAINERS - Detached, Unprotected} Buildings

NFPA 30, Flammable and Combustible Liquids Code, 13 Scope

NFPA 30, Flammable and Combustible Liquids Code, 13.1 Definitions

NFPA 30, Flammable and Combustible Liquids Code, 13.2 


\section{Codes and Standards Citations for Ethanol Fuel}

General Requirements

NFPA 30, Flammable and Combustible Liquids Code, 13.3

NFPA 13, Standard for the Installation of Sprinkler Systems Maximum Allowable Quantities and Maximum Storage Heights

NFPA 30, Flammable and Combustible Liquids Code, 13.6 Control Areas

NFPA 30, Flammable and Combustible Liquids Code, 13.7 Construction Requirements

NFPA 30, Flammable and Combustible Liquids Code, 13.9 Fire Protection

NFPA 30, Flammable and Combustible Liquids Code, 13.1 Emergency Control Systems

NFPA 30, Flammable and Combustible Liquids Code, 13.11 Electrical Systems

NFPA 30, Flammable and Combustible Liquids Code, 13.12 Containment, Drainage, and Spill Control

NFPA 30, Flammable and Combustible Liquids Code, 13.13 Ventilation

NFPA 30, Flammable and Combustible Liquids Code, 13.14 Exhausted Enclosures

NFPA 30, Flammable and Combustible Liquids Code, 13.15 Explosion Control

NFPA 30, Flammable and Combustible Liquids Code, 13.16 Separation from Incompatible Materials

NFPA 30, Flammable and Combustible Liquids Code, 13.17 Dispensing, Handling, and Use of Liquids in Detached, Unprotected Buildings

NFPA 30, Flammable and Combustible Liquids Code, 13.18 Outdoor Storage of Liquids

NFPA 30, Flammable and Combustible Liquids Code, 13.19

\section{OUTDOOR STORAGE}

NFPA 30, Flammable and Combustible Liquids Code, 15 Scope

NFPA 30, Flammable and Combustible Liquids Code, 15.1 Definitions

NFPA 30, Flammable and Combustible Liquids Code, 15.2 General Requirements

NFPA 30, Flammable and Combustible Liquids Code, 15.3 Outdoor Storage Adjacent to a Building

NFPA 30, Flammable and Combustible Liquids Code, 15.4 


\section{Codes and Standards Citations for Ethanol Fuel}

\section{AUTOMATIC FIRE PROTECTION FOR INSIDE LIQUID STORAGE AREAS}

Scope

NFPA 30, Flammable and Combustible Liquids Code, 16.1 Definitions

NFPA 30, Flammable and Combustible Liquids Code, 16.2 General Requirements

NFPA 30, Flammable and Combustible Liquids Code, 16.3 Automatic Sprinkler and Foam-Water Sprinkler Fire Protection Systems

NFPA 30, Flammable and Combustible Liquids Code, 16.4

NFPA 16, Standard for the Installation of Foam-Water Sprinkler and Foam-Water Spray Systems

NFPA 25, Standard for the Inspection, Testing, and Maintenance of Water-Based Fire Protection Systems

Fire Protection System Design Criteria

NFPA 30, Flammable and Combustible Liquids Code, 16.5

NFPA 13, Standard for the Installation of Sprinkler Systems

NFPA 16, Standard for the Installation of Foam-Water Sprinkler and

Foam-Water Spray Systems

UL 2368, Standard for Fire Exposure Testing of Intermediate Bulk

Containers for Flammable and Combustible Liquids

Fire Projection System Design Schemes

NFPA 30, Flammable and Combustible Liquids Code, 16.6

NFPA 13, Standard for the Installation of Sprinkler Systems Water Supply

NFPA 30, Flammable and Combustible Liquids Code, 16.7 Containment, Drainage, and Spill Control

NFPA 30, Flammable and Combustible Liquids Code, 16.8

NFPA 15, Standard for Water Spray Fixed Systems for Fire Protection

Other Automatic Fire Protection Systems

NFPA 30, Flammable and Combustible Liquids Code, 16.9

\section{STORAGE OF LIQUIDS IN TANKS - Requirements for all Tanks} Scope

NFPA 30, Flammable and Combustible Liquids Code, 21.1

Definitions

NFPA 30, Flammable and Combustible Liquids Code, 21.2 General Requirements

NFPA 30, Flammable and Combustible Liquids Code, 21.3

Design and Construction of Storage Tanks

NFPA 30, Flammable and Combustible Liquids Code, 21.4

API Tank Specifications

UL Tank Standards 


\section{Codes and Standards Citations for Ethanol Fuel}

ANSI Tank Standards

ASME Code for Unfired Pressure Vessels

ASME Boiler and Pressure Vessel Code

API Standard 2000, Venting Atmospheric and Low-Pressure Storage

Tanks

NFPA 69, Standard on Explosion Prevention Systems

NFPA 77, Recommended Practice on Static Electricity

Testing Requirements for Tanks

NFPA 30, Flammable and Combustible Liquids Code, 21.5

API 653, Tank Inspection, Repair, Alteration, and Reconstruction

Fire Prevention and Control

NFPA 30, Flammable and Combustible Liquids Code, 21.6

NFPA 25, Standard for the Inspection, Testing, and Maintenance of

Water-Based Fire Protection Systems

Operation of Storage Tanks

NFPA 30, Flammable and Combustible Liquids Code, 21.7

API 2350, Overfill Protection for Storage Tanks in Petroleum Facilities

NFPA 704, Standard System for the Identification of the Hazards of

Materials for Emergency Response

NFPA 326, Standard for the Safeguarding of Tanks and Containers

for Entry, Cleaning, or Repair

API Tank Cleaning Specifications

NFPA 329, Recommended Practice for Handling Releases of

Flammable and Combustible Liquids and Gases

Inspection and Maintenance of Storage Tanks and Storage Tank Appurtenances

NFPA 30, Flammable and Combustible Liquids Code, 21.8

API 653, Tank Inspection, Repair, Alteration, and Reconstruction

API 2350, Overfill Protection for Storage Tanks in Petroleum Facilities

API 12R1, Setting, Maintenance, Inspection, Operation, and Repair of

Tanks in Production Service

STI SP001, Standard for Inspection of Aboveground Storage Tanks

\section{STORAGE OF LIQUIDS IN TANKS - Aboveground Storage Tanks} Scope

NFPA 30, Flammable and Combustible Liquids Code, 22.1

Definitions

NFPA 30, Flammable and Combustible Liquids Code, 22.2

Location of Aboveground Storage Tanks

NFPA 30, Flammable and Combustible Liquids Code, 22.4

PEI RP200, Recommended Practices for Installation of Aboveground

Storage Systems for Motor Vehicle Fueling

Installation of Aboveground Storage Tanks

NFPA 30, Flammable and Combustible Liquids Code, 22.5

API 650, Welded Steel Tanks for Oil Storage 


\section{Codes and Standards Citations for Ethanol Fuel}

Vent Piping for Aboveground Tanks

NFPA 30, Flammable and Combustible Liquids Code, 22.6

Emergency Relief Venting for Fire Exposure for Aboveground Storage Tanks

NFPA 30, Flammable and Combustible Liquids Code, 22.7

Fire Protection for Aboveground Storage Tanks

NFPA 30, Flammable and Combustible Liquids Code, 22.8

NFPA 11,15 , and 69

UL 2080, Standard for Fire Resistant Tanks for Flammable and

Combustible Liquids

Additional Requirements for Fire-Resistant Aboveground Storage Tanks

NFPA 30, Flammable and Combustible Liquids Code, 22.9

Additional Requirements for Protected Aboveground Storage Tanks

NFPA 30, Flammable and Combustible Liquids Code, 22.10

UL 2085, Standards for Protected Aboveground Tanks for Flammable and Combustible Liquids

Control of Spills from Aboveground Storage Tanks

NFPA 30, Flammable and Combustible Liquids Code, 22.11

Equipment, Piping, and Fire Protection Systems in Remote Impoundment Areas and Diked Areas

NFPA 30, Flammable and Combustible Liquids Code, 22.12

Tank Openings Other than Vents

NFPA 30, Flammable and Combustible Liquids Code, 22.13

Aboveground Storage Tanks Located in Areas Subject to Flooding

NFPA 30, Flammable and Combustible Liquids Code, 22.14

Collision Protection for Aboveground Storage Tanks

NFPA 30, Flammable and Combustible Liquids Code, 22.15

Installation Instructions for Aboveground Storage Tanks

NFPA 30, Flammable and Combustible Liquids Code, 22.16

Inspection and Maintenance of Aboveground Storage Tanks

NFPA 30, Flammable and Combustible Liquids Code, 22.17

API 653, Tank Inspection, Repair, Alteration, and Reconstruction

STI SP001, Standard for Inspection of Aboveground Storage Tanks

\section{STORAGE OF LIQUIDS IN TANKS - Underground Tanks}

Scope

NFPA 30, Flammable and Combustible Liquids Code, 23.1

\section{Definitions}

NFPA 30, Flammable and Combustible Liquids Code, 23.2

General Requirements

NFPA 30, Flammable and Combustible Liquids Code, 23.3

API, ULC, STI, NACE, and UL Corrosion Protection Standards

UL, STI and API Underground Tank Specifications

Location of Underground Storage Tanks

NFPA 30, Flammable and Combustible Liquids Code, 23.4 


\section{Codes and Standards Citations for Ethanol Fuel}

Installation of Underground Storage Tanks

NFPA 30, Flammable and Combustible Liquids Code, 23.5

Normal Venting for Underground Storage Tanks

NFPA 30, Flammable and Combustible Liquids Code, 23.6

Control of Spills from Underground Storage Tanks

NFPA 30, Flammable and Combustible Liquids Code, 23.11

Tank Openings Other than Vents

NFPA 30, Flammable and Combustible Liquids Code, 23.13

Underground Storage Tanks Located in Areas Subject to Flooding

NFPA 30, Flammable and Combustible Liquids Code, 23.14

Installation Instructions for Underground Storage Tanks

NFPA 30, Flammable and Combustible Liquids Code, 23.16

Inspection and Maintenance of Underground Storage Tanks

NFPA 30, Flammable and Combustible Liquids Code, 23.17

\section{STORAGE TANK BUILDINGS}

Scope

NFPA 30, Flammable and Combustible Liquids Code, 24.1

Definitions

NFPA 30, Flammable and Combustible Liquids Code, 24.2

General Requirements

NFPA 30, Flammable and Combustible Liquids Code, 24.3

Location of Storage Tank Buildings

24.4 NFPA 30, Flammable and Combustible Liquids Code

NFPA 68, Standard on Explosion Protection by Deflagration Venting

Construction of Storage Tank Buildings

NFPA 30, Flammable and Combustible Liquids Code, 24.5

NFPA 220, Standard on Types of Building Construction

NFPA 101, Life Safety Code

Fire Protection for Storage Tank Buildings

NFPA 30, Flammable and Combustible Liquids Code, 24.6

NFPA 10, Standard for Portable Fire Extinguishers

NFPA 13, Standard for the Installation of Sprinkler Systems

NFPA 14, Standard for the Installation of Standpipe and Hose

Systems

NFPA 24, Standard for the Installation of Private Fire Service Mains

and Their Appurtenances

NFPA 11, 12, 12A, 15, 16, 17, and 25

Emergency Control Systems for Storage Tank Buildings

NFPA 30, Flammable and Combustible Liquids Code, 24.7

Electrical Systems for Storage Tank Buildings

NFPA 30, Flammable and Combustible Liquids Code, 24.8

Containment, Drainage, and Spill Control from Storage Tank Buildings

NFPA 30, Flammable and Combustible Liquids Code, 24.9 


\section{Codes and Standards Citations for Ethanol Fuel}

Ventilation for Storage Tank Buildings

NFPA 30, Flammable and Combustible Liquids Code, 24.10

NFPA 91, Standard for Exhaust Systems for Air Conveying of Vapors,

Gases, Mists, and Noncombustible Particulate Solids

NFPA 90A, Standard for the Installation of Air-Conditioning and

Ventilation Systems

Explosion Control

NFPA 30, Flammable and Combustible Liquids Code, 24.12

NFPA 13, Standard for the Installation of Sprinkler Systems

NFPA 15, Standard for Water Spray Fixed Systems for Fire

Protection

Vents for Tanks Inside Storage Tank Buildings

NFPA 30, Flammable and Combustible Liquids Code, 24.13

Tank Openings Other than Vents for Tanks Inside Storage Tank Buildings

NFPA 30, Flammable and Combustible Liquids Code, 24.14

Detection and Alarm Systems for Storage Tank Buildings

NFPA 30, Flammable and Combustible Liquids Code, 24.15

Inspection of Maintenance for Storage Tank Buildings

NFPA 30, Flammable and Combustible Liquids Code, 24.16

\section{STORAGE TANK VAULTS}

Scope

NFPA 30, Flammable and Combustible Liquids Code, 25.1

Definitions

NFPA 30, Flammable and Combustible Liquids Code, 25.2

General Requirements

NFPA 30, Flammable and Combustible Liquids Code, 25.3

ANSI/UL 2245, Standard for Below-Grade Vaults for Flammable

Liquid Storage Tanks

Location of Storage Tank Vaults

NFPA 30, Flammable and Combustible Liquids Code, 25.4

Construction and Installation of Storage Tank Vaults

NFPA 30, Flammable and Combustible Liquids Code, 25.5

Fire Protection for Storage Tank Vaults

NFPA 30, Flammable and Combustible Liquids Code, 25.6

Emergency Controls For Storage Tank Vaults

NFPA 30, Flammable and Combustible Liquids Code, 25.7

Electrical Systems for Storage Tank Vaults

NFPA 30, Flammable and Combustible Liquids Code, 25.8

Containment, Drainage, and Spill Control for Storage Tank Vaults

NFPA 30, Flammable and Combustible Liquids Code, 25.9

Ventilation Systems for Storage Tank Vaults

NFPA 30, Flammable and Combustible Liquids Code, 25.10 


\section{Codes and Standards Citations for Ethanol Fuel}

NFPA 91, Standard for Exhaust Systems for Air Conveying of Vapors, Gases, Mists, and Noncombustible Particulate Solids

Explosion Control

NFPA 30, Flammable and Combustible Liquids Code, 25.12 Vents for Tanks Inside Storage Tank Vaults

NFPA 30, Flammable and Combustible Liquids Code, 25.13 Tank Openings Other than Vents for Tanks Inside Storage Tank Vaults

NFPA 30, Flammable and Combustible Liquids Code, 25.14 Detection and Alarm Systems for Storage Tank Vaults

NFPA 30, Flammable and Combustible Liquids Code, 25.15 Inspection and Maintenance of Storage Tank Vaults and Equipment

NFPA 30, Flammable and Combustible Liquids Code, 25.16

\section{PROCESSING FACILITIES}

Scope

NFPA 30, Flammable and Combustible Liquids Code, 17.1

\section{Definitions}

NFPA 30, Flammable and Combustible Liquids Code, 17.2 General Requirements

NFPA 30, Flammable and Combustible Liquids Code, 17.3 Location of Process Vessels and Equipment

NFPA 30, Flammable and Combustible Liquids Code, 17.4 Accessibility

NFPA 30, Flammable and Combustible Liquids Code, 17.5 Construction Requirements

NFPA 30, Flammable and Combustible Liquids Code, 17.6

NFPA 5000, Building Construction and Safety Code

ICC International Building Code

NFPA 15, Standard for Water Spray Fixed Systems for Fire Protection

API 2218, Fireproofing Practices in Petroleum and Petrochemical

Processing Plants

NFPA 204, Standard for Smoke and Heat Venting

NFPA 101, Life Safety Code

NFPA 68, Standard on Explosion Protection by Deflagration Venting Containment, Drainage, and Spill Control

NFPA 30, Flammable and Combustible Liquids Code, 17.10

NFPA 15, Standard for Water Spray Fixed Systems for Fire Protection

Ventilation

NFPA 30, Flammable and Combustible Liquids Code, 17.11

NFPA 91, Standard for Exhaust Systems for Air Conveying of Vapors, Gases, Mists, and Noncombustible Particulate Solids 


\section{Codes and Standards Citations for Ethanol Fuel}

NFPA 90A, Standard for the Installation of Air-Conditioning and Ventilation Systems

Process Equipment and Vessels

NFPA 30, Flammable and Combustible Liquids Code, 17.14

NFPA 68, Standard on Explosion Protection by Deflagration Venting Management of Operations Hazards

NFPA 30, Flammable and Combustible Liquids Code, 17.15

\section{DISPENSING, HANDLING, TRANSFER, AND USE OF LIQUIDS}

Scope

NFPA 30A, Code for Motor Fuel Dispensing and Repair Garages, 6.1

NFPA 30, Flammable and Combustible Liquids Code, 18.1

Definitions

NFPA 30, Flammable and Combustible Liquids Code, 18.2

General Requirements

NFPA 30A, Code for Motor Fuel Dispensing and Repair Garages, 6.2 Requirements for Dispensing Devices

NFPA 30A, Code for Motor Fuel Dispensing and Repair Garages, 6.3 Requirements for Remote/Submersible Pumps

NFPA 30A, Code for Motor Fuel Dispensing and Repair Garages, 6.4 Requirements for Dispensing Hose

NFPA 30A, Code for Motor Fuel Dispensing and Repair Garages, 6.5 Requirements for Fuel Delivery Nozzles

NFPA 30A, Code for Motor Fuel Dispensing and Repair Garages, 6.6

UL 842, Standard for Valves for Flammable Fluids

Emergency Electrical Disconnects

NFPA 30A, Code for Motor Fuel Dispensing and Repair Garages, 6.7 Vapor Recovery Systems

NFPA 30A, Code for Motor Fuel Dispensing and Repair Garages, 6.8 Dispensing, Handling, Transfer, and Use of Liquids

NFPA 30, Flammable and Combustible Liquids Code, 18.3 Incidental Operations

NFPA 30, Flammable and Combustible Liquids Code, 18.4

NFPA 91, Standard for Exhaust Systems for Air Conveying of Vapors,

Gases, Mists, and Noncombustible Particulate Solids

Ventilation for Dispensing Areas

NFPA 30, Flammable and Combustible Liquids Code, 18.5

NFPA 91, Standard for Exhaust Systems for Air Conveying of Vapors,

Gases, Mists, and Noncombustible Particulate Solids

Component Standards

ANSI/UL 25, Meters for Flammable and Combustible Liquids

ANSI/UL 79, Flammable and Combustible Liquid Pumps for dispensing

UL 87, Power-Operated Dispensing Devices for Petroleum Products 


\section{Codes and Standards Citations for Ethanol Fuel}

UL 330, Hose and Hose Assemblies for Dispensing Flammable Liquids

ANSI/UL 331, Strainers for Flammable Fluids and Anhydrous Ammonia

UL 429, Electrical Valves, for use in control of dispensing equipment ANSI/UL 567, Emergency Breakaway Fittings, Swivel Connectors and

Pipe-Connection Fittings for Petroleum Products and LP-Gas ANSI/UL 842, Valves for Flammable Fluids

UL 860, Pipe Unions for Flammable and Combustible Fluids and FireProtection Service

\section{OPERATIONAL REQUIREMENTS}

Scope

NFPA 30A, Code for Motor Fuel Dispensing and Repair Garages, 9.1 Basic Requirements

NFPA 30A, Code for Motor Fuel Dispensing and Repair Garages, 9.2

NFPA 385, Standard for Tank Vehicles for Flammable and

Combustible Liquids

NFPA 10, Standard for Portable Fire Extinguishers

Operating Requirements for Full-Service Motor Fuel Dispensing Facilities

NFPA 30A, Code for Motor Fuel Dispensing and Repair Garages, 9.3

Operating Requirements for Attended Self-Service Motor Fuel Dispensing Facilities

NFPA 30A, Code for Motor Fuel Dispensing and Repair Garages, 9.4 Operating Requirement for Unattended Self-Service Motor Fuel Dispensing Facilities

NFPA 30A, Code for Motor Fuel Dispensing and Repair Garages, 9.5 Refueling from Tank Vehicles

NFPA 30A, Code for Motor Fuel Dispensing and Repair Garages, 9.6

NFPA 385, Standard for Tank Vehicles for Flammable and

Combustible Liquids

Repair Areas

NFPA 30A, Code for Motor Fuel Dispensing and Repair Garages, 9.7

NFPA 51B, Standard for Fire Prevention During Welding, Cutting, and Other Hot Work

NFPA 51, Standard for the Design and Installation of Oxygen-Fuel

Gas Systems for Welding, Cutting, and Allied Processes

NFPA 33, Standards for Spray Applications Using Flammable or Combustible Materials

NFPA 326, Standard for the Safeguarding of Tanks and Containers for Entry, Cleaning, or Repair

NFPA 31, Standards for the Installation of Oil-Burning Equipment

NFPA 54, National Fuel Gas Code

NFPA 85, Boiler and Combustion Systems Hazards Code 


\section{Codes and Standards Citations for Ethanol Fuel}

NFPA 55, Compressed Gases and Cryogenic Fluids Code

\section{PIPING FOR LIQUIDS}

Scope

NFPA 30A, Code for Motor Fuel Dispensing and Repair Garages, 5.1

NFPA 30, Flammable and Combustible Liquids Code, 27.1

Definitions

NFPA 30, Flammable and Combustible Liquids Code, 27.2

General Requirements for All Piping Systems

NFPA 30A, Code for Motor Fuel Dispensing and Repair Garages, 5.2

NFPA 30, Flammable and Combustible Liquids Code, 27.3

ASME B31, Code for Pressure Piping

API 607, Fire Test for Soft-Seated Quarter-Turn Valves

ASTM Piping Standards

Materials of Construction for Piping Systems

NFPA 30, Flammable and Combustible Liquids Code, 27.4

Pipe Joints

NFPA 30, Flammable and Combustible Liquids Code, 27.5

Installation of Piping Systems

NFPA 30A, Code for Motor Fuel Dispensing and Repair Garages, 5.3

NFPA 30, Flammable and Combustible Liquids Code, 27.6

Testing of Piping Systems

NFPA 30A, Code for Motor Fuel Dispensing and Repair Garages, 5.4

NFPA 30, Flammable and Combustible Liquids Code, 27.7

Detector Maintenance

NFPA 30A, Code for Motor Fuel Dispensing and Repair Garages, 5.5 Vent Piping

NFPA 30A, Code for Motor Fuel Dispensing and Repair Garages, 5.6

NFPA 30, Flammable and Combustible Liquids Code, 27.8

Vapor Recovery Piping

NFPA 30A, Code for Motor Fuel Dispensing and Repair Garages, 5.7 Bonding and Grounding

NFPA 30, Flammable and Combustible Liquids Code, 27.9 Identification and Marking of Piping Systems

NFPA 30, Flammable and Combustible Liquids Code, 27.10 Removal From Service of Piping Systems

NFPA 30, Flammable and Combustible Liquids Code, 27.12

\section{VAPOR PROCESSING AND VAPOR RECOVERY SYSTEMS FOR} LIQUID MOTOR FUELS

Vapor Processing Systems

NFPA 30A, Code for Motor Fuel Dispensing and Repair Garages, 10.1 


\section{Codes and Standards Citations for Ethanol Fuel}

Vapor Recovery Systems

NFPA 30A, Code for Motor Fuel Dispensing and Repair Garages, 10.2

\section{FARMS AND REMOTE SITES}

Scope

NFPA 30A, Code for Motor Fuel Dispensing and Repair Garages, 13.1

NFPA 30, Flammable and Combustible Liquids Code

Approved Storage

NFPA 30A, Code for Motor Fuel Dispensing and Repair Garages, 13.2

NFPA 30, Flammable and Combustible Liquids Code

Marking of Tanks and Containers

NFPA 30A, Code for Motor Fuel Dispensing and Repair Garages, 13.3

Fire Prevention and Control

NFPA 30A, Code for Motor Fuel Dispensing and Repair Garages, 13.4

\section{VEHICLE}

Fuels

ASTM D4814-07, Standard Specification for Automotive SparkIgnition Engine Fuel (E10)

ASTM D5798-06, Standard Specification for Fuel Ethanol (ED75Ed85) for Automotive Spark-Ignition Engines (E85)

ASTM D4806-06c, Standard Specification for Denatured Fuel Ethanol for Blending with Gasolines for Use as Automotive Spark-Ignition Engine Fuel

Systems

SAE J30, Fuel and Oil Hoses

SAE J254, Instrumentation and Techniques for Exhaust Gas Emissions Measurement

SAE J312, Automotive Gasolines

SAE J313, Diesel Fuels

SAE J607, Small Spark Ignition Engine Test Code

SAE J905, Fuel Filter Test Methods

SAE J1082, Fuel Economy Measurement-Road Test Procedure

SAE J1088, Test Procedure for the Measurement of Exhaust Emissions from Small Utility Engines

SAE J1094, Constant Volume Sampler System for Exhaust Emissions Measurement

SAE J1130, Determination of Emission from Gas Turbine Powered Light Duty Surface Vehicles 


\section{Codes and Standards Citations for Ethanol Fuel}

SAE J1256, Fuel Economy Measurement- Road Test ProcedureCold Start and Warm-up Fuel Economy

SAE J1297, Alternative Automotive Fuels

SAE J1312, Procedure for Mapping Engine Performance- Diesel and Spark Ignition Engines

SAE J1349, Engine Power Test Code- Spark ignition and Diesel

SAE J1350, Selection and Application Guidelines for Diesel, Gasoline, and Propane Fired Liquid Cooled Engine Pre-Heaters SAE J1376, Fuel Economy Measurement Test (Engineering Type) for Trucks and Buses

SAE J1498, Heating Values of Fuels

SAE J1829, Stoichiometric Ait/Fuel Ratios of Automotive Fuels

SAE J2785, Standardization of Color and Verbiage for Fuel Inlet Closures

SAE J2793, Fuel Dispensing Filter Test Methods- Draft document 


\section{Gaps in Codes and Standards}

Although used almost interchangeably with gasoline in FFVs, E85 has unique properties which distinguish it from gasoline. Thus, numerous gaps exist in the codes and standards for Ethanol as an alternative fuel. These include headspace flammability, component resistance, and effect of intermediate ethanol blends, as discussed in the following sections.

\section{Headspace flammability}

Due to the properties of ethanol (e.g., vapor pressure, flammable concentration range, flash point), the headspace vapors contained within a vessel above liquid ethanol may be flammable. Further research and subsequent standards for vehicles or storage will be required to address the headspace flammability issues; a few projects are currently underway.

\section{Ethanol Resistance}

Conflicting information related to the components of existing gasoline vehicles and their chemical and corrosion resistance to higher blends of ethanol exists. According to manufacturers of ethanol conversion kits, vehicles manufactured after the late 1980s contain components that are tolerant of ethanol because government regulations authorized the use of 10 percent ethanol in gasoline sold in the United States [28]. There is further supporting information on the resistance of many existing gasoline vehicle components to higher concentrations of ethanol [29]. However, it has long been suspected that many components on existing gasoline vehicles may not be resistant to Ethanol blends higher than 10 percent and will suffer from chemical degradation of elastomers and galvanic corrosion. The Coordinating Research Council, the State of Minnesota, and the Renewable Fuels Association are sponsoring research related to component durability at higher blends of ethanol [30]. While the results of those studies are only valid for intermediate blends of ethanol at 15 and 20 percent, they provide useful information for increasing ethanol blends above 10 percent. Several government-funded projects are underway to address these issues. Obviously, continued support of research to validate component compatibility to ethanol blends with higher concentrations of ethanol is required.

Components such as dispensing hoses, nozzles, and industrial forklift components may entirely lack a UL Listing for ethanol in blends greater than 10 percent. Providing data obtained through National Laboratory research or through supporting current research projects to standards developing organizations, the solution cited above, would facilitate development of Ethanol fuel component standards.

At this time, NFPA 30 and 30A do not address the properties of ethanol blends as a transportation fuel. Addressing ethanol compatibility with listed components is important for addressing the gap between the NFPA and standards, other code listing, and the use of components for ethanol. Providing research data or supporting current research projects is a likely solution. Furthermore, participation on the NFPA 30 and 30A technical committees responsible for writing the standards would also be productive in resolving component compatibility issues. 


\section{Storage}

As is the case with biodiesel, concerns regarding UL Listing of underground storage tanks used for ethanol exist [31]. Again, NFPA 30 cites UL Listings for underground storage tanks for flammable and combustible liquids. This issue creates a gap between an approved standard for components and AHJs and other regulatory bodies with concerns relative to that standard. Some of these concerns may be related to EPA's Underground Storage Tanks (UST) division on older tanks that may fail when used for higher ethanol blends. Also, a current program evaluates Ethanol's impact on tank leak detectors.

The key to addressing the gap between the NFPA standards listing and use of storage vessels for ethanol is addressing ethanol compatibility with listed storage vessels. Providing research data or supporting current research projects would be a likely solution. Furthermore, participation on the NFPA 30 and 30A technical committees responsible for writing the standards would also be productive in resolving the vessel compatibility issue.

\section{Emissions}

Emissions are a concern to both the EPA and DOE. Most states in EPA-regulated areas require emission testing for vehicles to ensure that individual vehicles meet state emission standards. State emission standards must meet the minimum requirements as set by the EPA federal emission standards. States are however, allowed to implement more stringent standards. These standards pertain primarily to tailpipe emissions. Increased use of Ethanol may pose unique emission concerns. Evaporative emissions associated with the use of ethanol in gasoline vehicles are a unique concern and need to be further explored. In addition, while higher blends of ethanol emissions are expected to produce less carbon monoxide in tailpipe emissions, production of compounds such as acetaldehyde and formaldehyde, which are currently non-regulated in vehicle emission standards, could potentially cause environmental and human health issues [32]. Furthermore, research on Ethanol blends and E85 in non-FFVs is required to address these issues.

\section{Conversion Kits}

Conversion kits to convert an existing gasoline vehicle to burn gasoline and/or E85 fuel are available for a limited number of vehicles. EPA certification is required for conversion to an FFV, just as it is with all conversions affecting fuel and emissions systems. There are a number of "conversion kits" on the market that are illegal to install on existing vehicles because they have not gone through EPA's certification process. Many of these are kits developed for foreign markets. Conversion kits for the Chrysler/Dodge 300 and Ford/Lincoln Crown Victoria vehicles model years 2005 and 2006 have been EPA certified. Currently, no streamlined EPA certification process exists for such kits. The expense of certification and the lack of an Ethanol-specific path for certification are the two most cited reasons for manufacturers not pursuing certification for their kits. Reducing the cost for EPA certification for E85 vehicle conversion kits would lead to more efficient methods of meeting the EPA requirements and increasing the number of Ethanol conversion vehicles. 


\section{Intermediate Ethanol Blend Research}

Lower concentrations of Ethanol can be blended with gasoline for use in gasoline vehicles to displace the use of fossil fuels; its use is defined as a "substantially similar" fuel. Currently, the use of 10 percent ethanol in most gasoline sold in the United States is standard practice. In 1992, an application for a waiver for 10 percent ethanol blends was submitted to the EPA for approval as a substantially similar fuel. However, the EPA never issued a ruling on the application and it became acceptable by default. Research is underway to enable the implementation of intermediate level ethanol blends at 15 and 20 percent. The result of successful implementation would enable a greater concentration of ethanol to be used in motor fuels to displace fossil fuel use. On April 6, 2009, an application was submitted to the EPA for the approval of fuel to include 15 percent ethanol. The United States Congress requires the EPA issue a ruling for 15 percent ethanol be issued by December 6, 2009 [32]. Continued efforts related to intermediate Ethanol blends will contribute to higher ethanol contents in gasoline and subsequent reduction in fossil fuel use.

\section{Flex Fuel Vehicles}

In addition to the lack of knowledge cited earlier regarding FFVs, one of the set-backs for owners or buyers of FFVs is the reputed large drop in fuel efficiency associated with the use of E85. While there is a drop in fuel economy because of the energy density reduction of E85 relative to gasoline, the finding of many drivers is that the drop in miles per gallon is larger than what is acceptable and results in a loss of cost-effectiveness relative to the use of straight gasoline. Current studies on mileage optimization efforts are addressing this issue. Additional research in this area with automotive manufacturers would benefit E85 use. One way to enhance this interaction is to continue and increase participation with the SAE committee responsible for producing an SAE Flex-Fuel Vehicle Standard.

\section{Summary}

Table 12 presents a summary of the identified Code and Standards Gaps for the expanded use of Ethanol as an alternative fuel. Also presented in the table is the impacted document and proposed means to address the gap. 
Table 12: Codes and Standards Gaps for Ethanol

\begin{tabular}{|c|c|c|}
\hline Vehicle Codes and Standards Gap & $\begin{array}{l}\text { Documents } \\
\text { Impacted }\end{array}$ & Gap Resolution \\
\hline $\begin{array}{l}\text { Compatibility with storage tanks } \\
\text { made for other fuels }\end{array}$ & $\begin{array}{l}\text { NFPA 30/30A } \\
\text { and associated } \\
\text { listing } \\
\text { documents, } \\
\text { EPA UST, IFC }\end{array}$ & $\begin{array}{l}\text { Provide data for the } \\
\text { compatibility of } \\
\text { Ethanol with listed } \\
\text { storage systems }\end{array}$ \\
\hline Flammability of Headspace vapor & $\begin{array}{l}\text { NFPA 30/30A, } \\
\text { IFC, SAE and } \\
\text { ASTM }\end{array}$ & $\begin{array}{l}\text { Provide data for the } \\
\text { implementation of } \\
\text { headspace } \\
\text { flammability } \\
\text { requirements in NFPA } \\
\text { documents }\end{array}$ \\
\hline $\begin{array}{l}\text { Component compatibility with high } \\
\text { ethanol concentrations }\end{array}$ & $\begin{array}{l}\text { NFPA 30/30A } \\
\text { and associated } \\
\text { listing } \\
\text { documents, } \\
\text { SAE, IFC }\end{array}$ & $\begin{array}{l}\text { Provide data for the } \\
\text { compatibility of } \\
\text { Ethanol with traditional } \\
\text { gasoline vehicle } \\
\text { components }\end{array}$ \\
\hline Certification of conversion kits & $\begin{array}{l}\text { EPA emission } \\
\text { regulations, } \\
\text { Technician and } \\
\text { Installer } \\
\text { Certification }\end{array}$ & $\begin{array}{l}\text { Streamline EPA } \\
\text { certification process } \\
\text { for conversion } \\
\text { components }\end{array}$ \\
\hline New emission profiles & $\begin{array}{l}\text { EPA emission } \\
\text { regulations }\end{array}$ & $\begin{array}{l}\text { Provide emission data } \\
\text { for intermediate } \\
\text { ethanol blends }\end{array}$ \\
\hline $\begin{array}{l}\text { Lower fuel cost offset by poor } \\
\text { mileage }\end{array}$ & $\begin{array}{l}\text { SAE engine } \\
\text { performance } \\
\text { documents }\end{array}$ & $\begin{array}{l}\text { Explore OEM tuning } \\
\text { practices of FFVs and } \\
\text { provide research for } \\
\text { mileage optimization } \\
\text { techniques }\end{array}$ \\
\hline No Standard for Flex Fuel Vehicles & SAE & $\begin{array}{l}\text { Support the } \\
\text { development of SAE } \\
\text { Standard for Flex Fuel } \\
\text { Vehicles }\end{array}$ \\
\hline
\end{tabular}


HYDROGEN 


\section{Hydrogen ${ }^{6}$}

\section{Background}

As mentioned earlier, implementing hydrogen technologies, particularly in the retail vehicle fuel-dispensing environment, requires significant new codes and standards development. Hydrogen has a long history of safe use in industrial applications. Codes and standards, in place for approximately 50 years, address these industrial applications [33]. By the early 1960s, the NFPA standards (NFPA 50A Standard for Gaseous Hydrogen Systems at Consumer Sites and NFPA 50B Standard for Liquefied Hydrogen Systems at Consumer Sites) addressed bulk storage of gaseous and liquefied hydrogen. These NFPA documents were incorporated into Occupational Safety and Health Administration (OSHA) regulations and appear in the Code of Federal Regulations (29 CFR 1910, Subpart H), Hazardous Materials.

In the 1990s, a significantly increased interest in using hydrogen as a fuel for fuel cell powered vehicles occurred. This new application would potentially require the development of public hydrogen fueling infrastructure as well as vehicular hydrogen standards. To store enough hydrogen on a vehicle to provide for an adequate vehicle driving range in the retail environment, the hydrogen storage pressure was increased to levels not typically encountered in the industrial environment. These high pressures create an additional safety concern. High-pressure hydrogen storage and delivery systems would thus be required on vehicles and at fuel dispensing stations. The general public would potentially have to handle high pressure dispensing equipment and maintenance would be required on high-pressure vehicle systems. These safety concerns are in the process of being translated into new requirements in codes and standards applicable to these applications.

Hydrogen gas cannot be odorized with conventional odorants, which are sulfur-based chemicals. These odorants will poison the fuel cell catalysts. This inability to odorize hydrogen used to power fuel cells, makes the use of sensing technologies an indispensable option to detect hydrogen releases.

In 2006, approximately 159 hydrogen powered vehicles existed in the United States. Although a relatively small number of vehicles, these are primarily prototype vehicles and represent a significant investment in hydrogen fuel cell vehicle technology. The majority of these vehicles and the associated fueling stations are located in California. The California Fuel Cell Partnership (CAFCP), instrumental in developing a fueling infrastructure in the California, offers a website [34] that contains information on the location of existing and proposed hydrogen fueling stations in California (http://www.fuelcellpartnership.org/).

One of the most important reasons for developing fuel cell vehicles or using hydrogen as a vehicle fuel is that hydrogen powered vehicles have no carbon emissions. This emissions characteristic is particularly important in large urban areas that fail to meet

\footnotetext{
${ }^{6}$ Expert discussion on the use of Hydrogen as an alternative fuel, included herein, was provided by Larry Fluer.
} 
federal air quality standards. California has several large urban areas that fail to meet these standards [EPA Greenbook July 31, 2009] including the Los Angeles metropolitan area, the largest metropolitan area in California [EPA Greenbook July 31, 2009] The CAFCP fuel station map shows that the largest numbers of hydrogen fueling stations are located in the Los Angeles metropolitan area.

One of the more rapidly growing markets today involves the use of hydrogen as an energy source for fuel cell powered industrial trucks (fork-lifts). Numerous fuel dispensing facilities are being installed to support the use of hydrogen as a fuel in warehouse operations throughout the country.

Hydrogen dispensing stations are located in other parts of the United States, including the following:

1. Detroit

2. Washington, DC

3. New Jersey

4. South Carolina

5. Florida

6. Arizona

7. Las Vegas, NV

8. Massachusetts

9. Pennsylvania

10. Texas

The following link provides additional information to the public regarding hydrogen vehicles, fueling infrastructure, costs, fuel prices, and other related information from the Alternative Fuels and Advanced Vehicles Data Center [35]: http://www.afdc.energy.gov/afdc/fuels/hydrogen.html.

Table 13: Codes and Standards for Hydrogen

\section{Codes and Standards Citations for Hydrogen Fuel}

\section{ANNUAL INSPECTIONS}

CGA G-5.4, Standard for Hydrogen Piping Systems at Consumer Locations

(Compressed Gas Association 2005)

7.0 Maintenance and Repair

CGA G-5.5, Hydrogen Vent Systems (Compressed Gas Association 2004)

9 Maintenance

IFC (International Code Council 2006)

406.2 Frequency

901.6.2 Records

907.2 Inspection, Testing, and Maintenance

2206.2.1.1 Inventory Control for Underground Tanks

3204.5.2 Corrosion Protection 


\section{Codes and Standards Citations for Hydrogen Fuel}

3205.4 Filling and Dispensing

NFPA 52, Vehicular Fuel Systems Code (National Fire Protection Association 2006)

9.2.15 General System Requirements

\section{BALANCE OF PLANT}

\section{Piping \& Tubing}

ASME B31.3, Process Piping (American Society of Mechanical Engineers 2006)

F323.4(5) Specific Material Considerations-Metals

IX K305 Pipe

ASME B31.12, Hydrogen Piping and Pipelines

CGA G-5.4, Standard for Hydrogen Piping Systems at Consumer Locations

(Compressed Gas Association 2005)

3.1 General

3.2 Piping Materials

5.0 Installation

5.1 Piping Installation General

5.2 Piping Installation Above Ground Installation

5.3 Piping Installation Underground Installation

IFC (International Code Council 2006)

2201.1 Scope

2209.3.2.3 Indoors

2209.3.2.6 Canopy Tops

3501.1 Scope

International Fuel Gas Code (International Code Council 2006)

101.2.1 Gaseous Hydrogen Systems

704 Piping, Use, and Handling

705 Testing of Hydrogen Piping Systems

NFPA 52, Vehicular Fuel Systems Code (National Fire Protection Association 2006)

9.8 Installation of Piping and Hoses

9.9 System Testing

NFPA 55, Standard for Storage, Use and Handling of Compressed Gases and Cryogenic Fluids in Portable and Stationary Containers, Cylinders and Tanks (National Fire Protection Association 2005)

11.2.3 Piping, Tubing, and Fittings

CGA H-3 Cryogenic Hydrogen Storage (Compressed Gas Association 2006) 10.0 External piping

\section{Pressure Relief}

CGA S-1.3, PRD Standards Part 3 - Stationary Storage Containers for

Compressed Gases (Compressed Gas Association 2005)

\subsubsection{Nonliquid Compressed Gases}




\section{Codes and Standards Citations for Hydrogen Fuel}

IFC (International Code Council 2006)

2209.2.1 Approved Equipment

2209.5.4.2 Pressure Relief Devices

3003.3 Pressure Relief Devices

3203.2 Pressure Relief Devices

3203.3 Pressure Relief Vent Piping

3203.5.4 Physical Protection

3203.8 Service and Repair

3205.1.2.3.2 Shutoff Valves on Piping

International Fuel Gas Code (International Code Council 2006)

703.3 Pressure Relief Devices

NFPA 52, Vehicular Fuel Systems Code (National Fire Protection Association 2006)

5.4 Pressure Relief Devices

5.6 Pressure Gauges

5.7 Pressure Regulators

9.6 Installation of Pressure Regulators

9.7 Installation of Pressure Gauges

14.6 Pressure Relief Devices

NFPA 55, Standard for Storage, Use and Handling of Compressed Gases and Cryogenic Fluids in Portable and Stationary Containers, Cylinders and Tanks (National Fire Protection Association 2005)

\subsubsection{Pressure-Relief Devices}

10.2.1 Pressure-Relief Devices

\section{Valving and Fittings}

ASME B31.3, Process Piping (American Society of Mechanical Engineers 2006)

IX K306 Fittings, Bends, and Branch Connections

IX K307 Valves and Specialty Components

CGA G-5.4, Standard for Hydrogen Piping Systems at Consumer Locations

(Compressed Gas Association 2005)

3.3.2 Isolation Valves

3.3.3 Emergency Isolation Valves

3.3.4 Excess Flow Valves

3.3.5 Check Valves

3.3.7 Gasket and Sealing Materials

3.3.8 Additional Requirements

5.0 Installation

5.1 Installation General

IFC (International Code Council 2006)

2209.5.2 Emergency Shutoff Valves

2211.8.1.2.4 Grounding and bonding

2703.2.2 Piping, Tubing, Valves, and Fittings

2703.9.3 Protection from Vehicles 


\section{Codes and Standards Citations for Hydrogen Fuel}

2703.10.1 Valve Protection

2705.1.10 Liquid Transfer

3003.6 Valve Protection

3005.3 Piping Systems

3005.4 Valves

3203.2.6 Shutoffs Between Pressure Relief Devices and Containers

3205.1.2 Piping Systems

3205.3.2 Emergency Shutoff Valves

3503.1.3 Emergency Shutoff

NFPA 52, Vehicular Fuel Systems Code (National Fire Protection Association 2006)

5.9 Valves

\section{Venting and Other Equipment}

CGA G-5.5, Hydrogen Vent Systems (Compressed Gas Association 2004)

6.0 Vent System

6.2 Sizing

6.3 Design

6.4 Materials

6.5 Components

7 Installation

IFC (International Code Council 2006)

2209.5.4 Venting of Hydrogen Systems

2211.8.1.2 Atmospheric Venting of Hydrogen from Motor Vehicle Fuel Storage Containers

3003.16.8 Connections

3005.5 Venting

3203.3 Pressure Relief Vent Piping

3204.4.5 Venting of Underground Tanks

International Fuel Gas Code (International Code Council 2006)

703.4 Venting

NFPA 52, Vehicular Fuel Systems Code (National Fire Protection Association 2006)

5.5 Vent Pipe Termination

9.3.3.3 Indoors

NFPA 55, Standard for Storage, Use and Handling of Compressed Gases and Cryogenic Fluids in Portable and Stationary Containers, Cylinders and Tanks (National Fire Protection Association 2005)

10.2.1.1 Pressure-Relief Devices

\section{CANOPY TOPS}

International Building Code (International Code Council 2009)

406.5.2.1 Canopies use to support gaseous hydrogen systems 


\section{Codes and Standards Citations for Hydrogen Fuel}

IFC (International Code Council 2006)

2209.3.2.6 Canopy Tops

2209.3.3 Canopies

NFPA 52, Vehicular Fuel Systems Code (National Fire Protection Association 2006)

\subsubsection{Outdoors}

\section{COMPRESSED HYDROGEN GAS STORAGE}

\section{Equipment Location}

IFC (International Code Council 2006)

2209.3 Location on Property

3503 General Requirements

3504 Storage

NFPA 52, Vehicular Fuel Systems Code (National Fire Protection Association 2006)

9.3 System Siting

NFPA 55, Standard for Storage, Use and Handling of Compressed Gases and Cryogenic Fluids in Portable and Stationary Containers, Cylinders and Tanks (National Fire Protection Association 2005)

10.3.2 Specific Requirements

\section{General Safety Requirements}

IFC (International Code Council 2006)

2209.5 Safety Precautions

2211.7 Repair Garages for Vehicles Fueled by Lighter-than-Air Fuels

2211.8 Defueling of Hydrogen from Motor Vehicle Fuel Storage

Containers

3003 General Requirements

3503 General Requirements

NFPA 52, Vehicular Fuel Systems Code (National Fire Protection Association 2006)

9.2.3 Equipment Security and Vehicle Protection

9.2.4 General System Requirements

9.2.5 General System Requirements

9.2.6 General System Requirements

9.2.7 General System Requirements

9.2.8 General System Requirements

9.2.9 General System Requirements

9.2.10 General System Requirements

9.2.11 General System Requirements

9.2.12 General System Requirements

9.2.13 General System Requirements

9.2.14 General System Requirements

9.2.15 General System Requirements 


\section{Codes and Standards Citations for Hydrogen Fuel}

9.2.16 General System Requirements

NFPA 55, Standard for Storage, Use and Handling of Compressed Gases and Cryogenic Fluids in Portable and Stationary Containers, Cylinders and Tanks (National Fire Protection Association 2005)

\subsubsection{Security}

\section{Storage Containers}

CGA PS-20, Direct Burial of Gaseous Hydrogen Storage Tanks (Compressed Gas Association 2006)

CGA PS-21, Adjacent Storage of Compressed Hydrogen and Other Flammable Gases (Compressed Gas Association 2005)

IFC (International Code Council 2006)

2703.2.1 Design and Construction of Containers, Cylinders, and

Tanks

3003.2 Design and Construction

3503.1.2 Storage Containers

NFPA 52, Vehicular Fuel Systems Code (National Fire Protection Association 2006)

5.3 Design and Construction of Containers

\section{COMPRESSION SYSTEMS AND EQUIPMENT}

IFC (International Code Council 2006)

2209.2 Equipment

2209.3 Location on Property

2209.5.3.1 System Requirements

2209.5.4.2.1 Minimum Rate of Discharge

NFPA 52, Vehicular Fuel Systems Code (National Fire Protection Association 2006)

9.2.7 General System Requirements

9.2.8 General System Requirements

9.2.9 General System Requirements

9.2.10 General System Requirements

9.2.11 General System Requirements

9.2.12 General System Requirements

9.2.13 General System Requirements

9.2.14 General System Requirements

9.3.1 General

14.8 Stationary Pumps and Compressors

\section{DESIGN}

\section{Barrier Walls}

IFC (International Code Council 2006)

2209.3.1.1 Barrier Wall Construction - Gaseous Hydrogen 


\section{Codes and Standards Citations for Hydrogen Fuel}

\section{Equipment}

International Fire Code (International Code Council 2006)

2209.2 Equipment

NFPA 52, Vehicular Fuel Systems Code (National Fire Protection Association 2006)

9.2 General System Requirements

\section{Fuel Stations}

IFC (International Code Council 2006)

35 Flammable Gases

2209.1 General

NFPA 30A, Code for Motor Fuel Dispensing Facilities and Repair Garages

(National Fire Protection Association 2003)

7.3 Motor Fuel Dispensing Facilities

NFPA 52, Vehicular Fuel Systems Code (National Fire Protection Association 2006)

9.3 System Siting

14.2 Facility Design

NFPA 55, Standard for Storage, Use and Handling of Compressed Gases and Cryogenic Fluids in Portable and Stationary Containers, Cylinders and Tanks

(National Fire Protection Association 2005)

7.1.6 Separation from Hazardous Conditions

\section{Weather Protection}

IFC (International Code Council 2006)

2209.3.2.2 Weather Protection

2704.13 Weather Protection

\section{DISPENSING}

\section{Electrical Equipment}

IFC (International Code Council 2006)

2201.5 Electrical

2205.4 Sources of Ignition

2209.2.3 Electrical Equipment

2211.3.1 Equipment

2211.8.1.2.4 Grounding and bonding

2703.9.4 Electrical Wiring and Equipment

3003.8 Wiring and Equipment

3003.16.14 Classified Areas

3203.7 Electrical Wiring and Equipment

3503.1.5.1 Bonding of Electrically Conductive Materials and

Equipment

NFPA 30A, Code for Motor Fuel Dispensing Facilities and Repair Garages

(National Fire Protection Association 2003) 


\section{Codes and Standards Citations for Hydrogen Fuel}

6.7 Emergency Electrical Disconnects

8 Electrical Installations

NFPA 52, Vehicular Fuel Systems Code (National Fire Protection Association 2006)

9.11 Installation of Electrical Equipment

9.12 Stray or Impressed Currents and Bonding

\section{Fuel Lines}

CGA G-5.4, Standard for Hydrogen Piping Systems at Consumer Locations

(Compressed Gas Association 2005)

3.0 Piping System Criteria

IFC (International Code Council 2006)

2201 Scope

2209.3.2.3 Indoors

2209.3.2.6 Canopy Tops

3501.1 Scope

International Fuel Gas Code (International Code Council 2006)

101.2.1 Gaseous Hydrogen Systems

704 Piping, Use, and Handling

705 Testing of Hydrogen Piping Systems

NFPA 52, Vehicular Fuel Systems Code (National Fire Protection Association 2006)

5.8 Fuel Lines

\section{Gaseous Dispensers}

IFC (International Code Council 2006)

2209.2 Equipment

2209.3 Location on Property

2209.4 Dispensing into Motor Vehicles at Self-Service Hydrogen

Motor Fuel-Dispensing Facilities

NFPA 52, Vehicular Fuel Systems Code (National Fire Protection Association 2006)

9.2 General System Requirements

9.3 System Siting

\section{Hoses and Connectors}

IFC (International Code Council 2006)

2209.2 Equipment

NFPA 52, Vehicular Fuel Systems Code (National Fire Protection Association 2006)
5.10 Hose and Hose Connections 


\section{Codes and Standards Citations for Hydrogen Fuel}

\section{Liquid Dispensers}

IFC (International Code Council 2006)

2206.7.4 Dispenser Emergency Valve

2206.7.5 Dispenser Hose

2206.7.6 Fuel Delivery Nozzles

2209.2 Equipment

2209.3 Location on Property

2209.4 Dispensing into Motor Vehicles at Self-Service Hydrogen

Motor Fuel-Dispensing Facilities

NFPA 30A, Code for Motor Fuel Dispensing Facilities and Repair Garages

(National Fire Protection Association 2003)

6.3 Requirements for Dispensing Devices

NFPA 52, Vehicular Fuel Systems Code (National Fire Protection Association 2006)

14 Liquid Hydrogen Fueling Facilities

\section{Vehicle Connectors}

NFPA 52, Vehicular Fuel Systems Code (National Fire Protection Association 2006)

5.11 Vehicle Fueling Connection

SAE J2600, Compressed Hydrogen Surface Vehicle Refueling Connection

Devices (Society of Automotive Engineers 2002)

\section{DISPENSING, OPERATIONS, AND MAINTENANCE SAFETY}

\section{Gaseous Hydrogen}

CGA G-5.5, Hydrogen Vent Systems (Compressed Gas Association 2004)

9 Maintenance

IFC (International Code Council 2006)

\section{Dispensing Operations}

2209.4 Dispensing into Motor Vehicles at Self-Service Hydrogen

Motor Fuel-Dispensing Facilities

NFPA 30A, Code for Motor Fuel Dispensing Facilities and Repair Garages

(National Fire Protection Association 2003)

9.2.2 Tank Filling and Bulk Delivery

9.4 Operating Requirements for Attended Self-Service Motor Fuel

Dispensing Facilities

9.5 Operating Requirements for Unattended Self-Service Motor Fuel

Dispensing Facilities

NFPA 52, Vehicular Fuel Systems Code (National Fire Protection Association 2006)

9.13 System Operation

9.14 Fire Protection

9.15 Maintenance System 


\section{Codes and Standards Citations for Hydrogen Fuel}

\section{Liquid Hydrogen}

CGA G-5.5, Hydrogen Vent Systems (Compressed Gas Association 2004)

9 Maintenance

IFC (International Code Council 2006)

\section{Dispensing Operations}

2209.4 Dispensing into Motor Vehicles at Self-Service Hydrogen

Motor Fuel-Dispensing Facilities

NFPA 30A, Code for Motor Fuel Dispensing Facilities and Repair Garages

(National Fire Protection Association 2003)

9.2.2 Tank Filling and Bulk Delivery

9.4 Operating Requirements for Attended Self-Service Motor Fuel

Dispensing Facilities

9.5 Operating Requirements for Unattended Self-Service Motor Fuel

Dispensing Facilities

NFPA 52, Vehicular Fuel Systems Code (National Fire Protection Association 2006)

14.4.6 Liquid Hydrogen Vehicle Dispensing Systems

14.4.9 Liquid Hydrogen Vehicle Dispensing Systems

14.4.10 Liquid Hydrogen Vehicle Dispensing Systems

14.4.11 Liquid Hydrogen Vehicle Dispensing Systems

14.13 Maintenance

\section{FIRE SAFETY}

\section{Construction}

IFC (International Code Council 2006)

911 Explosion Control

2209.5 Safety Precautions

International Fuel Gas Code (International Code Council 2006)

706.3 Outdoor Gaseous Hydrogen Systems

NFPA 52, Vehicular Fuel Systems Code (National Fire Protection Association 2006)

9.12 Stray or Impressed Currents and Bonding

NFPA 55, Standard for Storage, Use and Handling of Compressed Gases and Cryogenic Fluids in Portable and Stationary Containers, Cylinders and Tanks

(National Fire Protection Association 2005)

7.1.6 Separation from Hazardous Conditions

\section{Equipment}

IFC (International Code Council 2006)

404 Fire Safety and Evacuation Plan

406 Employee Training and Response Procedures

407 Hazard Communication

906 Portable Fire Extinguishers

907 Fire Alarm and Detection Systems 


\section{Codes and Standards Citations for Hydrogen Fuel}

2209.4 Dispensing into Motor Vehicles at Self-Service Hydrogen

Motor Fuel-Dispensing Facilities

2209.5 Safety Precautions

NFPA 52, Vehicular Fuel Systems Code (National Fire Protection Association 2006)

9.2.3 Equipment Security and Vehicle Protection

9.2.4 General System Requirements

9.2.5 General System Requirements

9.2.15 General System Requirements

9.3.3 Indoors

9.14 Fire Protection

14.2.4 Indoor Fueling

14.4.3 Liquid Hydrogen Vehicle Dispensing Systems

\section{Signage}

IFC (International Code Council 2006)

2204.3.5 Emergency Procedures

2209.5.2.1 Identification

NFPA 52, Vehicular Fuel Systems Code (National Fire Protection Association 2006)

9.3.3.12 Warning Signs

NFPA 55, Standard for Storage, Use and Handling of Compressed Gases and Cryogenic Fluids in Portable and Stationary Containers, Cylinders and Tanks (National Fire Protection Association 2005)

6.12 Hazard Identification Signs

10.2.4 Marking

11.3.1.4 General

\section{LIQUID HYDROGEN STORAGE}

\section{Equipment Location}

IFC (International Code Council 2006)

2209.3 Location on Property

3203.5.4 Physical Protection

3203.6 Separation from Hazardous Conditions

3204.3.1.1 Location

3204.4.2 Location

3504 Storage

NFPA 55, Standard for Storage, Use and Handling of Compressed Gases and Cryogenic Fluids in Portable and Stationary Containers, Cylinders and Tanks (National Fire Protection Association 2005)

11.3.1 General

11.3.2 Specific Requirements 


\section{Codes and Standards Citations for Hydrogen Fuel}

\section{General Safety Requirements}

IFC (International Code Council 2006)

2209.5 Safety Precautions

2211.7 Repair Garages for Vehicles Fueled by Lighter-than-Air Fuels

2211.8 Defueling of Hydrogen from Motor Vehicle Fuel Storage

Containers

3003 General Requirements

3203 General Safety Requirements

3503 General Requirements

NFPA 52, Vehicular Fuel Systems Code (National Fire Protection Association 2006)

14.2 Facility Design

\section{Storage Containers}

IFC (International Code Council 2006)

2703.2 Systems, Equipment, and Processes

3203.1 Containers

3203.5 Security

3203.6 Separation from Hazardous Conditions

3204.3.1 Stationary Containers

3204.4 Underground Tanks

NFPA 52, Vehicular Fuel Systems Code (National Fire Protection Association 2006)

5.3 Design and Construction of Containers

NFPA 55, Standard for Storage, Use and Handling of Compressed Gases and Cryogenic Fluids in Portable and Stationary Containers, Cylinders and Tanks (National Fire Protection Association 2005)

11.3.2 Specific Requirements

11.4.2 Underground Tanks

CGA H-3 Cryogenic Hydrogen Storage (Compressed Gas Association 2006)

6.0 Tank design and manufacturing criteria

7.0 Inner vessel

8.0 Outer jacket

\section{ON-SITE HYDROGEN PRODUCTION}

IFC (International Code Council 2006)

2209.3.1 Separation from Outdoor Exposure Hazards

International Fuel Gas Code (International Code Council 2006)

703.1 General Requirements

NFPA 52, Vehicular Fuel Systems Code (National Fire Protection Association 2006)

\subsection{System Approvals}




\section{Codes and Standards Citations for Hydrogen Fuel}

\section{OPERATION APPROVALS}

Dispensing

IFC (International Code Council 2006)

2204.2 Attended Self-Service Motor Fuel-Dispensing Facilities

2204.3 Unattended Self-Service Motor Fuel-Dispensing Facilities

2209.4 Dispensing into Motor Vehicles at Self-Service Hydrogen

Motor Fuel-Dispensing Facilities

NFPA 30A, Code for Motor Fuel Dispensing Facilities and Repair Garages

(National Fire Protection Association 2003)

6.2 General Requirements

6.3 Requirements for Dispensing Devices

NFPA 52, Vehicular Fuel Systems Code (National Fire Protection Association 2006)

14.4.1 Liquid Hydrogen Vehicle Dispensing Systems

14.4.2 Liquid Hydrogen Vehicle Dispensing Systems

14.4.3 Liquid Hydrogen Vehicle Dispensing Systems

14.4.11 Liquid Hydrogen Vehicle Dispensing Systems

Fire And Emergency Planning

IFC (International Code Council 2006)

404 Fire Safety and Evacuation Plan

406 Employee Training and Response Procedures

407 Hazard Communication

906 Portable Fire Extinguishers

907 Fire Alarm and Detection Systems

2209.3.2.6.2 Fire-Extinguishing Systems

2209.4 Dispensing into Motor Vehicles at Self-Service Hydrogen

Motor Fuel-Dispensing Facilities

2209.5.1 Protection from Vehicles

2209.5.2 Emergency Shutoff Valves

2209.5.3 Emergency Shutdown Controls

2209.5.4 Venting of Hydrogen Systems

NFPA 30A, Code for Motor Fuel Dispensing Facilities and Repair Garages

(National Fire Protection Association 2003)

7.3.5 Fixed Fire Protection

NFPA 52, Vehicular Fuel Systems Code (National Fire Protection Association 2006)

9.2.16 General System Requirements

9.10.5 Installation of Emergency Shutdown Equipment

NFPA 55, Standard for Storage, Use and Handling of Compressed Gases and Cryogenic Fluids in Portable and Stationary Containers, Cylinders and Tanks (National Fire Protection Association 2005)

4.1 Permits

4.2 Emergency Plan 


\section{Codes and Standards Citations for Hydrogen Fuel}

\subsubsection{Separation from Hazardous Conditions}

\section{Fuel Delivery}

IFC (International Code Council 2006)

105.6.8 Compressed Gases

105.6.10 Cryogenic Fluids

2205.1 Tank Filling Operation for Class I, II, or IIIA Liquids

3205.4 Filling and Dispensing

NFPA 30A, Code for Motor Fuel Dispensing Facilities and Repair Garages

(National Fire Protection Association 2003)

6.3.7 Requirements for Dispensing Devices

NFPA 52, Vehicular Fuel Systems Code (National Fire Protection Association 2006)

9.2.3 Equipment Security and Vehicle Protection

NFPA 55, Standard for Storage, Use and Handling of Compressed Gases and Cryogenic Fluids in Portable and Stationary Containers, Cylinders and Tanks (National Fire Protection Association 2005)

10.3 Location of Gaseous Hydrogen Systems

\section{Ignition Control}

IFC (International Code Council 2006)

2209.3.2.3.3 Ignition Source Control

3503.1.4 Ignition Source Control

NFPA 55, Standard for Storage, Use and Handling of Compressed Gases and Cryogenic Fluids in Portable and Stationary Containers, Cylinders and Tanks (National Fire Protection Association 2005)

\subsection{Ignition Source Controls}

7.6.3 Ignition Source Control

\section{Personnel Issues and Training}

IFC (International Code Council 2006)

406 Employee Training and Response Procedures

2209.4 Dispensing into Motor Vehicles at Self-Service Hydrogen

Motor Fuel-Dispensing Facilities

NFPA 30A, Code for Motor Fuel Dispensing Facilities and Repair Garages

(National Fire Protection Association 2003)

9.4 Operating Requirements for Attended Self-Service Motor Fuel

Dispensing Facilities

NFPA 55, Standard for Storage, Use and Handling of Compressed Gases and Cryogenic Fluids in Portable and Stationary Containers, Cylinders and Tanks (National Fire Protection Association 2005)

4.6 Personnel Training

4.7 Fire Department Liaison 


\section{Codes and Standards Citations for Hydrogen Fuel}

\section{Signage}

IFC (International Code Council 2006)

2204.3.5 Emergency Procedures

2209.3.2.3.2 Smoking

2209.3.2.6.3 Signage

2209.5.2.1 Identification

NFPA 52, Vehicular Fuel Systems Code (National Fire Protection Association 2006)

9.3.3.12 Warning Signs

NFPA 55, Standard for Storage, Use and Handling of Compressed Gases and Cryogenic Fluids in Portable and Stationary Containers, Cylinders and Tanks

(National Fire Protection Association 2005)

\subsection{Signs}

\section{Vehicle Access}

IFC (International Code Council 2006)

105.6.8 Compressed Gases

105.6.10 Cryogenic Fluids

105.6.39 Repair Garages and Motor Fuel-Dispensing Facilities

404.3.2 Fire Safety Plans

3205.4 Filling and Dispensing

NFPA 30A, Code for Motor Fuel Dispensing Facilities and Repair Garages

(National Fire Protection Association 2003)

6.3.7 Requirements for Dispensing Devices

NFPA 52, Vehicular Fuel Systems Code (National Fire Protection Association 2006)

9.2.3 Equipment Security and Vehicle Protection

14.2.1.6 General

14.4.2 Liquid Hydrogen Vehicle Dispensing Systems

14.4.5 Liquid Hydrogen Vehicle Dispensing Systems

NFPA 55, Standard for Storage, Use and Handling of Compressed Gases and

Cryogenic Fluids in Portable and Stationary Containers, Cylinders and Tanks

(National Fire Protection Association 2005)

10.3 Location of Gaseous Hydrogen Systems

\section{SETBACKS AND FOOTPRINTS}

\section{Liquid Systems}

IFC (International Code Council 2006)

2209.3.1 Separation from Outdoor Exposure Hazards

NFPA 52, Vehicular Fuel Systems Code (National Fire Protection Association 2006)

14.2.2 Siting 


\section{Codes and Standards Citations for Hydrogen Fuel}

NFPA 55, Standard for Storage, Use and Handling of Compressed Gases and Cryogenic Fluids in Portable and Stationary Containers, Cylinders and Tanks (National Fire Protection Association 2005)

11.3.2.1 Specific Requirements

11.3.2.2 Specific Requirements

\section{Outdoor Gaseous Systems}

IFC (International Code Council 2006)

2209.3.1 Separation from Outdoor Exposure Hazards

NFPA 52, Vehicular Fuel Systems Code (National Fire Protection Association 2006)

\subsubsection{General}

NFPA 55, Standard for Storage, Use and Handling of Compressed Gases and Cryogenic Fluids in Portable and Stationary Containers, Cylinders and Tanks (National Fire Protection Association 2005)

10.3.2.1 Specific Requirements

10.3.2.2 Minimum Distance

\section{TRANSPORTATION}

\section{Compressed Hydrogen Gas}

CGA P-1, Safe Handling of Compressed Gases in Containers (Compressed Gas Association 2006)

4.1 Transportation Regulating Authorities

4.2 Container Regulations

4.3 Container Filling Regulations

4.4 Regulating Authorities of Employee Safety and Health

6.2 Flammable Gases

IFC (International Code Council 2006)

2705 Use, Dispensing, and Handling

3005.7 Transfer

3505 Use

NFPA 55, Standard for Storage, Use and Handling of Compressed Gases and Cryogenic Fluids in Portable and Stationary Containers, Cylinders and Tanks (National Fire Protection Association 2005)

4 General Requirements

7.3.1.10 Use and Handling

\section{Liquid Hydrogen}

CGA P-12, Safe Handling of Cryogenic Liquids (Compressed Gas Association 2005)

5.5.4 Additional Safety Practices for Liquid Hydrogen

6.4 Hydrogen Fires

7.9 Handling Considerations for Hydrogen and Helium Transfer 


\section{Codes and Standards Citations for Hydrogen Fuel}

IFC (International Code Council 2006)

2705 Use Dispensing and Handling

3201.1 Scope

3203.6.1.1 Point-of-Fill Connections

3205.4.2 Vehicle Loading and Unloading Areas

NFPA 52, Vehicular Fuel Systems Code (National Fire Protection Association 2006)

14.3 Cargo Transport Unloading

NFPA 55, Standard for Storage, Use and Handling of Compressed Gases and Cryogenic Fluids in Portable and Stationary Containers, Cylinders and Tanks

(National Fire Protection Association 2005)

4 General Requirements

8.3.5 Overfilling

8.13.1.2 Attended Delivery

8.13.10.3 Filling and Dispensing

\section{Natural Gas}

ASME B31.8, Gas Transmission and Distribution Systems (American Society of Mechanical Engineers 2003)

\section{VAPORIZERS}

IFC (International Code Council 2006)

2209.2 Equipment

2209.3 Location on Property

3203.1.3 Foundations and Supports

3203.2.2 Vessels or Equipment Other than Containers

3203.5.3 Securing of Vaporizers

IFC (International Code Council 2006)

708 Design of Liquefied Hydrogen Systems Associated with

Hydrogen Vaporization Operations

NFPA 55, Standard for Storage, Use and Handling of Compressed Gases and Cryogenic Fluids in Portable and Stationary Containers, Cylinders and Tanks (National Fire Protection Association 2005)

11.2.5 Liquefied Hydrogen Vaporizers 


\section{Gaps in Codes and Standards}

Hydrogen has been safely used in industrial applications for many years. However, fueling applications for vehicle hydrogen fuel cell vehicles are relatively new. It should be viewed that such fueling station operations will ultimately evolve into routine consumer interaction. Few incident data exists on hydrogen vehicle fueling operations. The lack of data translates into limited fueling specific information on which to base operating and maintenance requirements for hydrogen fueling operations. On the other hand, a significant amount of data has been collected regarding the use of hydrogen systems in industrial applications. The industrial database is used as the basis for generic information relative to the construction of the typical system upon which the prototypical fueling systems are based. Over time fueling specific experience will add to the available data used in the ongoing evolution of codes and standards as the retail sector matures. In the interim, this lack of fueling specific data on the use of hydrogen in potential retail situations drives many of the hydrogen codes and standards research needs.

Industrial use of hydrogen has required the development of a hydrogen production and transportation infrastructure that is relatively mature [33]. The regulations to transport hydrogen by pipeline, rail, and road vehicle were promulgated in 49 CFR 100-192 [36]. However, the consumer market infrastructure is not fully developed. Codes and standards are developing for transport, storage, delivery, and use of hydrogen in vehicles.

Table 14 presents a summary of the identified Code and Standards Gaps for the expanded use of Hydrogen as an alternative fuel. Also, the table presents the impacted document and proposed means to address the gap.

Table 14 illustrates the various areas of hydrogen codes and standards that require additional work in order to create a complete and standardized control strategy. One key area that may require additional work is operations and maintenance requirements for fuel dispensing systems. This area is of particular concern because relatively little data for the use of vehicular hydrogen dispensing systems exists. As data is accrued, it may become apparent that additional safety measures are needed to address operations and maintenance. A second area of concern is potential releases of hydrogen in confined spaces such as indoor fueling operations, tunnels, and parking garages. The release characteristics and prevention and mitigation measures vary for these different locations, but many of the same analytical tools can be used to characterize the hazards of these releases. A third area of concern is the hazard presented by the potential energy contained in high-pressure storage and dispensing systems. Table 14 lists several other important gaps that require further work. 
Table 14: Codes and Standards Gaps for Hydrogen

\begin{tabular}{|c|c|c|}
\hline Codes or Standard Gap & $\begin{array}{l}\text { Documents } \\
\text { Impacted }\end{array}$ & Gap Resolution \\
\hline No final fuel quality standard & $\begin{array}{l}\text { ISO Fuel Quality } \\
\text { Draft International } \\
\text { Standard, } \\
\text { ASTM analysis } \\
\text { standards, } \\
\text { SAE Technical } \\
\text { Information } \\
\text { Report (TIR) } \\
\text { J2719 }\end{array}$ & $\begin{array}{l}\text { Provide data to ensure that } \\
\text { draft standards become } \\
\text { final standards }\end{array}$ \\
\hline $\begin{array}{l}\text { Potentially incomplete } \\
\text { requirements for indoor } \\
\text { hydrogen vehicle dispensing }\end{array}$ & NFPA 52, IFC & $\begin{array}{l}\text { Evaluate indoor release } \\
\text { characteristics and accident } \\
\text { scenarios for potential } \\
\text { application to code } \\
\text { development }\end{array}$ \\
\hline $\begin{array}{l}\text { Off road vehicle storage tank } \\
\text { standards are incomplete }\end{array}$ & $\begin{array}{l}\text { CSA America } \\
\text { Heavy Goods } \\
\text { Vehicle (HGV) } \\
4.3, \text { SAE J2601 }\end{array}$ & $\begin{array}{l}\text { Support standards } \\
\text { development work with } \\
\text { direct committee } \\
\text { involvement and data } \\
\text { support }\end{array}$ \\
\hline $\begin{array}{l}\text { Bulk liquefied hydrogen } \\
\text { storage requirements lack } \\
\text { technical basis } \\
\text { documentation }\end{array}$ & $\begin{array}{l}\text { NFPA } 55, \text { NFPA } \\
2 \text {, IFC }\end{array}$ & $\begin{array}{l}\text { Evaluate liquid release } \\
\text { impacts and frequencies } \\
\text { and provide this information } \\
\text { to relevant technical } \\
\text { committees to validate or } \\
\text { revise bulk liquefied } \\
\text { hydrogen storage } \\
\text { requirements }\end{array}$ \\
\hline $\begin{array}{l}\text { Requirements for tunnels, } \\
\text { parking garages, and repair } \\
\text { garages need review to } \\
\text { determine whether additional } \\
\text { requirements for hydrogen } \\
\text { are needed [meeting with } \\
\text { New York Port Authority } \\
\text { January 2009] }\end{array}$ & $\begin{array}{l}\text { NFPA 505, IFC, } \\
\text { NFPA 88B, NFPA } \\
30 A, \text { IBC, } \\
\text { International } \\
\text { Mechanical Code } \\
\text { (IMC) }\end{array}$ & $\begin{array}{l}\text { Evaluate safety concerns in } \\
\text { these environments and } \\
\text { work with the technical } \\
\text { committees to provide data } \\
\text { required to address codes } \\
\text { and standards requirements }\end{array}$ \\
\hline
\end{tabular}




\begin{tabular}{|l|l|l|}
\hline \multicolumn{1}{|c|}{ Codes or Standard Gap } & \multicolumn{1}{|c|}{$\begin{array}{c}\text { Documents } \\
\text { Impacted }\end{array}$} & \multicolumn{1}{|c|}{ Gap Resolution } \\
\hline $\begin{array}{l}\text { Operations and maintenance } \\
\text { procedures lack supporting } \\
\text { operational history data } \\
\text { [conversation with Larry } \\
\text { Fluer] }\end{array}$ & $\begin{array}{l}\text { NFPA 52, NFPA } \\
\text { 30A, IFC }\end{array}$ & $\begin{array}{l}\text { Evaluate existing } \\
\text { procedures to determine } \\
\text { where they might be } \\
\text { incomplete. } \\
\text { Evaluate operations and } \\
\text { maintenance history for } \\
\text { similar fuels to determine } \\
\text { whether useful information } \\
\text { can be retrieved and } \\
\text { applied to hydrogen }\end{array}$ \\
\hline $\begin{array}{l}\text { Steam Methane Reformation } \\
\text { (SMR) plants do not have a } \\
\text { safety standard [conversation } \\
\text { with Roger Smith] }\end{array}$ & $\begin{array}{l}\text { No current code } \\
\text { specifically } \\
\text { addresses SMR } \\
\text { plants }\end{array}$ & $\begin{array}{l}\text { Develop a code or standard } \\
\text { that addresses SMR plants }\end{array}$ \\
\hline $\begin{array}{l}\text { New storage systems, such } \\
\text { as metal hydrides, are } \\
\text { minimally addressed in codes } \\
\text { and standards }\end{array}$ & $\begin{array}{l}\text { NFPA 55, CGA H- } \\
1 \text { and H-2, IFC }\end{array}$ & $\begin{array}{l}\text { Determine whether new } \\
\text { chemical storage systems } \\
\text { are adequately addressed } \\
\text { in codes and standards }\end{array}$ \\
\hline $\begin{array}{l}\text { Limited familiarity with } \\
\text { relevant hydrogen codes and } \\
\text { standards among project } \\
\text { developers and code officials } \\
\text { [conversation with Larry } \\
\text { Fluer] }\end{array}$ & $\begin{array}{l}\text { All hydrogen } \\
\text { codes and } \\
\text { standards }\end{array}$ & $\begin{array}{l}\text { Regional codes and } \\
\text { standards workshops as } \\
\text { well as web training and } \\
\text { background information can } \\
\text { help address this issue }\end{array}$ \\
\hline $\begin{array}{l}\text { Incomplete requirements for } \\
\text { sensing technologies [Rivkin } \\
\text { analysis of NFPA 52] }\end{array}$ & $\begin{array}{l}\text { NFPA 52, NFPA } \\
55\end{array}$ & $\begin{array}{l}\text { Support the use of sensing } \\
\text { technologies that replace } \\
\text { odorants through evaluating } \\
\text { sensing technologies and } \\
\text { supporting code and } \\
\text { standards development } \\
\text { work in sensing } \\
\text { technologies }\end{array}$ \\
\hline $\begin{array}{l}\text { High-pressure storage, } \\
\text { handling, and use of } \\
\text { hydrogen [David Farese DOE } \\
\text { Safety Panel meeting] }\end{array}$ & $\begin{array}{l}\text { NFPA 52, NFPA } \\
\text { of documents }\end{array}$ & $\begin{array}{l}\text { Evaluate codes and } \\
\text { standards that address } \\
\text { high-pressure storage to } \\
\text { determine if requirements } \\
\text { are adequate and if } \\
\text { additional work is required }\end{array}$ \\
\hline
\end{tabular}




\begin{tabular}{|l|l|l|}
\hline \multicolumn{1}{|c|}{ Codes or Standard Gap } & \multicolumn{1}{|c|}{$\begin{array}{c}\text { Documents } \\
\text { Impacted }\end{array}$} & \multicolumn{1}{|c|}{ Gap Resolution } \\
\hline $\begin{array}{l}\text { Global Technical Regulations } \\
\text { (GTR) }\end{array}$ & $\begin{array}{l}\text { Coordination with } \\
\text { SAE and DOT } \\
\text { regulations }\end{array}$ & $\begin{array}{l}\text { Continue to represent the } \\
\text { United States in GTR } \\
\text { development meetings and } \\
\text { evaluate impacts of GTR in } \\
\text { domestic regulations, } \\
\text { codes, and standards }\end{array}$ \\
\hline $\begin{array}{l}\text { Coordination of international } \\
\text { (primarily ISO) standards and } \\
\text { domestic codes and } \\
\text { standards }\end{array}$ & $\begin{array}{l}\text { Multiple } \\
\text { documents: SAE, } \\
\text { CSA, UL, NFPA }\end{array}$ & $\begin{array}{l}\text { Evaluate component } \\
\text { standards to ensure that } \\
\text { there are not unnecessary } \\
\text { conflicts }\end{array}$ \\
\hline $\begin{array}{l}\text { The DOT guidance } \\
\text { documents for incidents } \\
\text { involving flammable gases } \\
\text { are too general and } \\
\text { prescriptive }\end{array}$ & $\begin{array}{l}\text { DOT Emergency } \\
\text { Response Guide }\end{array}$ & $\begin{array}{l}\text { Add additional material to } \\
\text { the DOT guide for hydrogen } \\
\text { incidents }\end{array}$ \\
\hline
\end{tabular}


ELECTR ICITY 


\section{Electricity ${ }^{7}$}

\section{Background}

Electric Vehicles (EVs) are designed and used on a marginal basis since the inception of internal combustion automobiles. In the 1970s through 1980s, a few vehicles were produced commercially, but in relatively small number. These vehicles had driving ranges of 50 to 60 miles and were intended for urban use [37]. In the 1990s, some of the first efforts were started by large car companies to develop EVs that would eventually have widespread use. These vehicles, using mostly lead acid batteries, had driving ranges fewer than 100 miles per charge. This generation of vehicles is no longer in production.

\section{Codes and Standards Structure}

The codes and standards structure for EVs are characterized as follows:

1. Electric grid regulations: National Institute of Standards, Federal Energy Regulatory Commission,

2. Interface between the vehicle and the grid: Institute of Electrical and Electronics Engineers (IEEE) standards, SAE Standards,

3. Vehicle charging station construction: NFPA 70 National Electrical Code (NEC), and

4. Vehicle components and systems: SAE standards.

Appendix II has a complete overview of EV code and standards including an extensive analysis of the SAE EV standards.

\section{Gaps in Codes and Standards}

\section{Grid}

The grid communication standards that allow for densely concentrated charging and the selection by consumers of electricity produced in different ways are not in place. These standards offer consumers the choice of purchasing electricity for charging their vehicles from different sources of electricity. For example, a consumer could purchase electricity produced entirely from renewable energy technologies.

\section{Interface}

Several SAE standards address vehicle to charging station interface requirements. These documents include SAE J-2836 and SAE J-2847 and are both under development with expected publication in 2010 .

SAE J-1772 and J-1773 address the hardware for vehicle charging and are currently under revision with new editions expected to be issued in 2010.

\footnotetext{
${ }^{7}$ Expert discussion on the use of Electricity and support technology as an alternative fuel, included herein, was provided by Roland Pitts (Battery Technology), Kathryn Clay (OEM perspective), Mark Kosowski (Electric Vehicles) and Chris Sloane.
} 


\section{Vehicle}

Battery technologies comprise a critical component of the EV, including hybrids, plug-in hybrids, and entirely EVs. Thus, a critical consideration for the utilization of electricity as an alternative vehicular fuel would be the battery. While the classic lead acid battery is still commonly deployed in automobiles and other applications (e.g., stationary systems for backup power [38]), it is not used for vehicular motive power. The power density of 180 watts per kilogram $(\mathrm{W} / \mathrm{kg})$ is too low. Alternative battery technologies with higher power densities are used for vehicular power. The currently deployed fleet of hybrids typically uses the Nickel-Metal Hydride (NiMH) batteries. However, owing to improved performance specifications and excellent power density (up to $340 \mathrm{~W} / \mathrm{Kg}$ ), the lithium ion battery (Li-ion) is projected to be used in the next generation of hybrid vehicles, including the plug-in hybrids.

Based on discussions with industry representatives, it is believed that the short-term standardization of battery technology and support systems (charging units, operational protocols, interconnects, and safety interlocks) for EVs may be problematic. In part, this problem is because of the rapid development of new battery technologies. More important, however, is that the OEMs have an entrenched attitude of maintaining a degree of control of critical vehicle components. Historically, this attitude is particularly applied to the power system (engine and transmission). Engine performance was a source of pride between various models and their customers. Electric motors and batteries are now replacing the internal combustion engine, and a desire to keep the development of the new power system in-house exists. Significant progress is underway in the area of battery technology for vehicles. It is likely that unique performance advantages are achieved with proprietary developments. Thus, OEM control over the power system will not only help maintain uniqueness of the OEM product, but could also provide a competitive edge in the event of a technological development. It is critical to set basic operational codes and standards early in the emerging market of EVs. Such vehicle code and standards are best addressed by working with the trade groups of the OEMs. Such an interaction has been initiated between NREL and the Alliance for Automobile Manufacturer.

\section{Lithium Ion Battery}

The Li-ion battery is a relatively new technology that went through a rapid developmental process. Various design changes implemented since its introduction have dramatically improved the overall performance in terms of power and lifetime. The term, Li-ion battery, refers to various cell designs with unique cathodes, anodes, electrolytes, and performance parameters such as cell voltage, temperature stability, etc. The Li-ion battery is already the mainstay of small appliances and electronics, such as battery packs for portable computers. One shortcoming in the Li-ion battery is that it is expensive, especially relative to other battery types. This cost is not because of costly material of construction but rather the complexity of the battery design itself; the sensitivity of the Li- ion battery to temperature and over charging requires intricate self-contained protection systems. A range of integrated safety controls incorporated into the lithium ion battery design includes pressure release vents, thermal protection systems, and shut down systems. Chargers are more expensive than other battery systems because of non-uniform size and composition of the Li-ion class of batteries; emphasizing the need for 
establishing standards for battery-based vehicular power system. For all the required complexity, Li-ion batteries are commercially successful, and the production cost is expected to drop as manufacturing techniques develop. However, higher throughput further emphasizes the need to identify technical issues and concerns for the Li-ion battery and to implement codes and standards that provide guidance on performance and safety requirements to manufacturers before the products reach the consumers.

Vehicular codes and standards for the Li-ion battery are not yet completely developed. Although commercially mature for some markets, the Li-ion battery is not deployed in consumer vehicles. It has however been used in engineering prototype vehicles. To form the necessary framework for the required codes and standards, some critical issues of the lithium battery should be summarized. In a lead acid battery, each cell has a nominal potential of 2.1 volts and uses aqueous sulfuric acid electrolyte (a standard 12 volt automobile battery is comprised of 6 cells connected in series). A typical Li-ion cell has a potential of over 3.2 volts. Different components for the anode, cathode of electrolyte are used in various designs of the Li-ion battery. Depending upon design selection, individual cell voltage varies by as much as 700 millivolts $(\mathrm{mV})$, which must be considered for use of a Li-ion battery in critical applications. Regardless of design, the cell voltage of the Liion battery dramatically exceeds the stable potential window afforded by aqueous electrolytes. Thus, non-aqueous electrolytes are used. Specifically, solvent mixtures containing ethylene carbonate and other organic solvents with a dissolved salt such as lithium hexafluorophosphate $\left(\mathrm{LiPF}_{6}\right)$, lithium hexafluoroborate $\left(\mathrm{LiBF}_{6}\right)$, or lithium perchlorate $\left(\mathrm{LiClO}_{4}\right)$ are typically used. Ethylene carbonate is an organic solvent and is flammable, thus, in the case of a rupture, a combustion hazard can occur. Recently one battery pack design used in laptop computers failed and burned sufficiently enough to force the Federal Aviation Administration to consider banning Li-ion batteries on commercial flights (the problem with this particular battery design was located and rectified to improve reliability). Ethylene carbonate is not volatile at room temperature, but can vaporize at elevated temperatures (boiling point equals $248^{\circ} \mathrm{C}$ ), which is easily encountered in fires. The vapors of many organic compounds are potentially toxic.

Although neither OSHA nor the National Institute for Occupational Safety and Health (NIOSH) currently consider ethylene carbonate to be overly toxic when inhaled, vapors of other components in the electrolyte may be highly toxic. These components are not yet specified for the "standard" Li-ion battery.

Volatility of the battery components, especially the electrolyte may pose additional risks. In addition to fires and the possible generation of potentially toxic vapors, volatilization increases the internal pressure of the battery, and ultimately, at sufficiently elevated pressures, the structural integrity of the battery housing will be breached. The resulting rupture is quite dramatic, perhaps resulting in an explosion. The most likely mechanism for volatilization of components is thermal-induced increases in vapor pressure, but chemical or electrochemical decomposition of components to more volatile products can also occur. Indeed, overcharging may result in the degradation of the organic solvent at the anode. Thermal excursions occur because of fire resulting from, for example, an accident with a conventional gasoline-powered vehicle, as well as internal thermal 
runaway within the Li-ion battery itself. Operation of the battery also generates heat, and thus a ventilated enclosure might be necessary.

While the Li-ion battery exhibits a slow self-discharge rate that is significantly better than the nickel metal hydride (NiMH) (5 to 10 percent per month compared to 30 percent), the service lifetime is less than desired. Further, the service lifetime includes the shelf-life of the battery. Adverse treatment can also affect the service lifetime, including over charging or under charging (or discharging below a threshold voltage, which may induce irreversible side reactions). Treatment suggestions for prolonged lifetime include the following:

- Charge lithium batteries often; but if unused for an extended time leave at a 40 to 60 percent charge,

- Avoid regular deep cycle discharge,

- Avoid elevated temperature,

- Avoid extreme cold (do not freeze the solvent; an issue at ca. -40), and

- Buy new batteries as needed and keep track of shelf-life, including distributor inventories.

\section{Nickel Metal Hydride Battery}

The currently deployed fleet of hybrid vehicles typically uses NiMH batteries. A critical advantage is the exceptional power density of up $1,000 \mathrm{~W} / \mathrm{kg}$. The individual cell potential of the NiMH battery is between 1.4 and 1.6 volts and thus is compatible with aqueous electrolytes. However, the NiMH battery has a high self-discharge rate (up to 30 percent per month), thus a purely EV might run out of fuel if allowed to sit unattended for moderately extended periods. Like the classic lead acid battery, hydrogen generation is a probable side product from over charging, although the amount of hydrogen generation is significantly less for the NiMH battery. Reverse polarity of a cell or individual battery causes irreversible damage, and occurs during normal operation if one battery in a multipack becomes discharged before others. Protection systems are needed.

\section{Summary}

Table 15 presents a summary of the identified Code and Standards Gaps for the expanded use of Electricity as an alternative fuel. The table also presents the impacted document and proposed means to address the gap. 
Table 15: Gaps in Electricity Codes and Standards

\begin{tabular}{|c|c|c|}
\hline Codes or Standard Gap & Documents Impacted & Gap Resolution \\
\hline $\begin{array}{l}\text { Code enforcers lack of } \\
\text { familiarity with charging } \\
\text { station requirements, } \\
\text { particularly for home } \\
\text { charging stations }\end{array}$ & NFPA 70, Article 625 & $\begin{array}{l}\text { Education and outreach } \\
\text { required to increase } \\
\text { familiarity with the NFPA } \\
70 \text { requirements }\end{array}$ \\
\hline $\begin{array}{l}\text { Battery standards are not } \\
\text { complete, specifically: } \\
\text { 1. SAE } 1797 \text { does } \\
\text { not address } \\
\text { lithium lon } \\
\text { batteries } \\
\text { 2. SAE J1798 does } \\
\text { not address } \\
\text { temperature } \\
\text { testing } \\
\text { 3. SAE } 2288 \text { does } \\
\text { not address } \\
\text { temperature } \\
\text { variation and } \\
\text { testing } \\
\text { 4. SAE } 2380 \text { does } \\
\text { not address } \\
\text { battery mounting } \\
\text { and vibration } \\
\text { testing }\end{array}$ & $\begin{array}{l}\text { SAE J1797, SAE J1798, } \\
\text { SAE J 2288, SAE J } 2380\end{array}$ & $\begin{array}{l}\text { The standards } \\
\text { development activities } \\
\text { need to be monitored to } \\
\text { ensure that the required } \\
\text { data are available to the } \\
\text { technical committees to } \\
\text { promulgate their revised } \\
\text { documents }\end{array}$ \\
\hline $\begin{array}{l}\text { Communications } \\
\text { between the vehicle and } \\
\text { the grid require further } \\
\text { definition }\end{array}$ & $\begin{array}{l}2293 \text { - Updates for } \\
\text { current communication } \\
\text { technology - Nat Labs } \\
\text { participation } \\
2836 \text { - Part 1, 2, } 3 \text { all } \\
\text { need updates for } \\
\text { communication } \\
\text { requirements } \\
2847 \text { - Part 1, 2, } 3 \text { not } \\
\text { complete, need technical } \\
\text { requirements for } \\
\text { communications }\end{array}$ & $\begin{array}{l}\text { The standards } \\
\text { development activities } \\
\text { need to be monitored to } \\
\text { ensure that the required } \\
\text { data are available to the } \\
\text { technical committees to } \\
\text { promulgate their revised } \\
\text { documents }\end{array}$ \\
\hline
\end{tabular}




\begin{tabular}{|l|l|l|}
\hline Codes or Standard Gap & Documents Impacted & \multicolumn{1}{|c|}{ Gap Resolution } \\
\hline $\begin{array}{l}\text { Communications within } \\
\text { the grid to balance } \\
\text { vehicle charging loads }\end{array}$ & $\begin{array}{l}\text { National Institute of } \\
\text { Standards and } \\
\text { Technology (NIST) } \\
\text { standards, IEEE 1547 }\end{array}$ & $\begin{array}{l}\text { The codes and standards } \\
\text { activities require } \\
\text { monitoring to determine } \\
\text { where data are needed } \\
\text { to ensure that the } \\
\text { documents are } \\
\text { promulgated }\end{array}$ \\
\hline
\end{tabular}


OEM Comments 


\section{OEM Comments}

This report focused primarily on the alternative fuel itself and the related infrastructure. Along the continuum from fuel production, quality, distribution and use there are numerous issues that need to be addressed regarding codes and standards. In many cases, these have been addressed to some extent, for alternative fuels. However, new technologies and the application of these technologies are always evolving, and codes and standards must do the same. Another perspective to be considered in the development of codes and standards for the vehicle industry is the $\mathrm{OEM}^{8}$. Naturally, vehicle OEMs maintain a vested interest in the codes and standards for the new alternative fuels. In the Electricity section of this report, the role of OEM on the development of new electric power systems and its impact on the standardization of new battery systems was briefly discussed. Significant improvements in battery technology for vehicle power progressed in the past few years. This improvement trend will continue. In order to maintain a competitive edge and unique product features, some OEM may develop new technologies using in-house resources as opposed to outsourcing. Thus new EV power systems will develop in parallel, rendering it difficult to implement short-term standardization. Also, a different philosophy pertaining to safety engineering exists within the OEM. From the OEM perspective, identifying potential scenarios, assessing potential impacts, and then developing standards and implementing codes to mitigate against deleterious effects of possible events is less productive than engineering designs that render the event unlikely. More precisely, vehicles and support systems/infrastructure should be designed so that the probability of a specific event occurring is at an acceptably low probability rate (as is the case with existing vehicle fuel systems).

\footnotetext{
${ }^{8}$ Expert discussion on the OEM perspective, included herein, was provided by Kathryn Clay and Chris Sloan.
} 
CONCLUS ION 


\section{Conclusion}

The previous sections presented the status of the code and standards for each of the alternative fuels. For several fuels, the codes and standards structure is well-defined and nearly complete with few gaps that may impede further implementation. In other cases, significant gaps are present which impact the deployment at significant levels. However, common issues exist that crosscut all the identified fuel types. For transportation applications, several newer fuels and emerging technologies present a lack of familiarity among consumers. Furthermore, significant outreach efforts targeting AHJs and project developers are required to gain sufficient familiarity with new fuel types to allow safe implementation of new fuel stations.

Finally, one of the most important factors for addressing codes and standards gaps for alternative fuels is the continuation of the comprehensive approach outlined on Page 4 of this document. As previously stated, the effort modeled after the program implemented for the promulgation of hydrogen codes and standards should continue to be supported for all alternative fuels. The result will ensure efficiency and the avoidance of conflicts in DOEs work on alternative fuels codes and standards.

\section{Gaps in Existing Vehicle Codes and Standards}

Table 16 contains the most important code and standards gaps and gap resolutions by fuel. Some gaps applied to all fuels and are listed at the end of the table.

Table 16: Summary of Vehicle Codes and Standards Gaps

\begin{tabular}{|c|l|l|l|}
\hline Fuel & \multicolumn{1}{|c|}{$\begin{array}{c}\text { Vehicle Codes and } \\
\text { Standards Gap }\end{array}$} & $\begin{array}{c}\text { Documents } \\
\text { Impacted }\end{array}$ & \multicolumn{1}{|c|}{ Gap Resolution } \\
\hline BIODIESEL & $\begin{array}{l}\text { Lack of data for existing } \\
\text { codes and standards } \\
\text { applicability to biodiese } \\
\text { storage systems }\end{array}$ & $\begin{array}{l}\text { National Fire } \\
\text { Protection } \\
\text { Association (NFPA) } \\
30 \text { and 30A and } \\
\text { associated listing } \\
\text { documents, IFC }\end{array}$ & $\begin{array}{l}\text { Provide data for the } \\
\text { compatibility of } \\
\text { Biodiesel with listed } \\
\text { storage }\end{array}$ \\
\hline BIODIESEL & $\begin{array}{l}\text { Limited component } \\
\text { compatibility }\end{array}$ & $\begin{array}{l}\text { Multiple Society of } \\
\text { Automotive } \\
\text { Engineers (SAE) } \\
\text { documents }\end{array}$ & $\begin{array}{l}\text { Work with SAE } \\
\text { committees and } \\
\text { provide data to } \\
\text { support changes } \\
\text { allowing for more } \\
\text { component flexibility }\end{array}$ \\
\hline
\end{tabular}




\begin{tabular}{|c|c|c|c|}
\hline Fuel & $\begin{array}{l}\text { Vehicle Codes and } \\
\text { Standards Gap }\end{array}$ & $\begin{array}{l}\text { Documents } \\
\text { Impacted }\end{array}$ & Gap Resolution \\
\hline ELECTRICITY & $\begin{array}{l}\text { Code enforcers lack of } \\
\text { familiarity with charging } \\
\text { station requirements, } \\
\text { particularly for home } \\
\text { charging stations }\end{array}$ & $\begin{array}{l}\text { NFPA 70, Article } \\
625\end{array}$ & $\begin{array}{l}\text { Education and } \\
\text { outreach required to } \\
\text { increase familiarity } \\
\text { with the NFPA } 70 \\
\text { requirements }\end{array}$ \\
\hline ELECTRICITY & $\begin{array}{l}\text { Battery standards are } \\
\text { not complete, } \\
\text { specifically: } \\
\text { 1. SAE } 1797 \text { does not } \\
\text { address lithium lon } \\
\text { batteries } \\
\text { 2. SAE J1798 does not } \\
\text { address temperature } \\
\text { testing } \\
\text { 3. SAE } 2288 \text { does not } \\
\text { address temperature } \\
\text { variation and testing } \\
\text { 4. SAE } 2380 \text { does not } \\
\text { address battery } \\
\text { mounting and } \\
\text { vibration testing }\end{array}$ & $\begin{array}{l}\text { SAE J1797, SAE } \\
\text { J1798, SAE J 2288, } \\
\text { SAE J } 2380\end{array}$ & $\begin{array}{l}\text { The standards } \\
\text { development } \\
\text { activities need to be } \\
\text { monitored to ensure } \\
\text { that the required } \\
\text { data are available to } \\
\text { the technical } \\
\text { committees to } \\
\text { promulgate their } \\
\text { revised documents }\end{array}$ \\
\hline ELECTRICITY & $\begin{array}{l}\text { Communications } \\
\text { between the vehicle and } \\
\text { the grid require further } \\
\text { definition }\end{array}$ & $\begin{array}{l}2293 \text { - Updates for } \\
\text { current } \\
\text { communication } \\
\text { technology - Nat } \\
\text { Labs participation } \\
2836 \text { - Part 1, 2, } 3 \\
\text { all need updates for } \\
\text { communication } \\
\text { requirements } \\
2847 \text { - Part 1, 2, } 3 \\
\text { not complete, need } \\
\text { technical } \\
\text { requirements for } \\
\text { communications }\end{array}$ & $\begin{array}{l}\text { The standards } \\
\text { development } \\
\text { activities need to be } \\
\text { monitored to ensure } \\
\text { that the required } \\
\text { data are available to } \\
\text { the technical } \\
\text { committees to } \\
\text { promulgate their } \\
\text { revised documents }\end{array}$ \\
\hline
\end{tabular}




\begin{tabular}{|c|c|c|c|}
\hline Fuel & $\begin{array}{l}\text { Vehicle Codes and } \\
\text { Standards Gap }\end{array}$ & $\begin{array}{l}\text { Documents } \\
\text { Impacted }\end{array}$ & Gap Resolution \\
\hline ELECTRICITY & $\begin{array}{l}\text { Communications within } \\
\text { the grid to balance } \\
\text { vehicle charging loads }\end{array}$ & $\begin{array}{l}\text { National Institute of } \\
\text { Standards and } \\
\text { Technology (NIST) } \\
\text { standards, Institute } \\
\text { of Electrical and } \\
\text { Electronics } \\
\text { Engineers (IEEE) } \\
1547\end{array}$ & $\begin{array}{l}\text { The codes and } \\
\text { standards activities } \\
\text { require monitoring to } \\
\text { determine where } \\
\text { data are needed to } \\
\text { ensure that the } \\
\text { documents are } \\
\text { promulgated }\end{array}$ \\
\hline ETHANOL & $\begin{array}{l}\text { Component compatibility } \\
\text { with high ethanol } \\
\text { concentration mixtures }\end{array}$ & $\begin{array}{l}\text { NFPA } 30 / 30 A \text { and } \\
\text { associated listing } \\
\text { documents, SAE } \\
2835\end{array}$ & $\begin{array}{l}\text { Provide data for the } \\
\text { compatibility of } \\
\text { Ethanol with } \\
\text { traditional gasoline } \\
\text { vehicle components }\end{array}$ \\
\hline ETHANOL & $\begin{array}{l}\text { Lack of data for existing } \\
\text { codes and standards } \\
\text { applicability to Ethanol } \\
\text { storage systems }\end{array}$ & $\begin{array}{l}\text { NFPA } 30 / 30 \mathrm{~A} \text { and } \\
\text { associated listing } \\
\text { documents, IFC }\end{array}$ & $\begin{array}{l}\text { Provide data for the } \\
\text { compatibility of } \\
\text { Ethanol with listed } \\
\text { storage }\end{array}$ \\
\hline HYDROGEN & $\begin{array}{l}\text { High pressure storage, } \\
\text { handling, and use of } \\
\text { hydrogen presents } \\
\text { hazards specific to high- } \\
\text { pressure systems that } \\
\text { may not be completely } \\
\text { addressed }\end{array}$ & $\begin{array}{l}\text { NFPA 2, NFPA 52, } \\
\text { NFPA 55 } \\
\text { Compressed Gas } \\
\text { Association (CGA) H } \\
\text { series of documents, } \\
\text { International Fire } \\
\text { Code (IFC) }\end{array}$ & $\begin{array}{l}\text { Evaluated codes } \\
\text { and standards that } \\
\text { address high } \\
\text { pressures to } \\
\text { determine if } \\
\text { requirements are } \\
\text { adequate }\end{array}$ \\
\hline HYDROGEN & $\begin{array}{l}\text { Incomplete } \\
\text { requirements for } \\
\text { sensing technologies }\end{array}$ & $\begin{array}{l}\text { NFPA 2, NFPA 52, } \\
\text { NFPA 55, IFC }\end{array}$ & $\begin{array}{l}\text { Support the use of } \\
\text { sensing } \\
\text { technologies that } \\
\text { replace odorants } \\
\text { through evaluating } \\
\text { sensing } \\
\text { technologies and } \\
\text { supporting code and } \\
\text { standards } \\
\text { development work in } \\
\text { sensing } \\
\text { technologies }\end{array}$ \\
\hline
\end{tabular}




\begin{tabular}{|c|c|c|c|}
\hline Fuel & $\begin{array}{l}\text { Vehicle Codes and } \\
\text { Standards Gap }\end{array}$ & $\begin{array}{l}\text { Documents } \\
\text { Impacted }\end{array}$ & Gap Resolution \\
\hline HYDROGEN & $\begin{array}{l}\text { Off-road vehicle storage } \\
\text { tank requirements are } \\
\text { incomplete }\end{array}$ & $\begin{array}{l}\text { Codes and } \\
\text { Standards of } \\
\text { America (CSA) } \\
\text { Heavy Goods } \\
\text { Vehicle (HGV) 2, } \\
\text { SAE J2601, } \\
\text { Underwriters' } \\
\text { Laboratories, Inc. } \\
\text { (UL) } 2267\end{array}$ & $\begin{array}{l}\text { Support standards } \\
\text { development work } \\
\text { with direct } \\
\text { committee } \\
\text { involvement and } \\
\text { data support }\end{array}$ \\
\hline HYDROGEN & $\begin{array}{l}\text { Potentially incomplete } \\
\text { requirements for indoor } \\
\text { hydrogen fueling }\end{array}$ & NFPA 52, IFC & $\begin{array}{l}\text { Evaluate indoor } \\
\text { release } \\
\text { characteristics and } \\
\text { accident scenarios } \\
\text { for potential } \\
\text { application to code } \\
\text { development }\end{array}$ \\
\hline NG & $\begin{array}{l}\text { Outreach products for } \\
\text { installation technicians } \\
\text { and conversion shops }\end{array}$ & Multiple & $\begin{array}{l}\text { Produce outreach } \\
\text { products for } \\
\text { consumers, } \\
\text { installation shops, } \\
\text { and technicians }\end{array}$ \\
\hline NG & $\begin{array}{l}\text { Component } \\
\text { standardization }\end{array}$ & Multiple documents & $\begin{array}{l}\text { Support } \\
\text { development of } \\
\text { component } \\
\text { standards }\end{array}$ \\
\hline PROPANE & Conversion components & $\begin{array}{l}\text { NFPA } 58 \text { or UL } \\
\text { listing document }\end{array}$ & $\begin{array}{l}\text { Provide data to } \\
\text { ensure component } \\
\text { listings are valid }\end{array}$ \\
\hline PROPANE & $\begin{array}{l}\text { Compositional and fuel } \\
\text { quality concerns }\end{array}$ & $\begin{array}{l}\text { American Society for } \\
\text { Testing and } \\
\text { Materials (ASTM) D } \\
1835-97\end{array}$ & $\begin{array}{l}\text { Provide data from } \\
\text { the analysis of fuel } \\
\text { quality and impact } \\
\text { on vehicle systems }\end{array}$ \\
\hline
\end{tabular}




\begin{tabular}{|c|c|c|c|}
\hline Fuel & $\begin{array}{l}\text { Vehicle Codes and } \\
\text { Standards Gap }\end{array}$ & $\begin{array}{l}\text { Documents } \\
\text { Impacted }\end{array}$ & Gap Resolution \\
\hline ALL FUELS & $\begin{array}{l}\text { Focus research } \\
\text { activities on system } \\
\text { engineering to reduce } \\
\text { the probability of a } \\
\text { release or incident } \\
\text { rather than evaluating } \\
\text { the potential impacts of } \\
\text { a release or incident }\end{array}$ & Multiple documents & $\begin{array}{l}\text { Conduct more } \\
\text { research on system } \\
\text { safety engineering } \\
\text { rather than modeling } \\
\text { of incidents }\end{array}$ \\
\hline ALL FUELS & $\begin{array}{l}\text { Lack of familiarity with } \\
\text { codes and standards } \\
\text { among project } \\
\text { developers and AHJs }\end{array}$ & Multiple documents & $\begin{array}{l}\text { Continue to conduct } \\
\text { regional training } \\
\text { workshops and } \\
\text { develop specialized } \\
\text { web education } \\
\text { products }\end{array}$ \\
\hline ALL FUELS & $\begin{array}{l}\text { Develop operational } \\
\text { safety requirements for } \\
\text { fueling operations as } \\
\text { data are accrued } \\
\text { through learning } \\
\text { demonstrations }\end{array}$ & Multiple documents & $\begin{array}{l}\text { Analyze fueling } \\
\text { data, particularly for } \\
\text { new fueling } \\
\text { technologies at } \\
\text { facilities with } \\
\text { multiple fuels, to } \\
\text { determine whether } \\
\text { operations safety } \\
\text { can be increased }\end{array}$ \\
\hline
\end{tabular}




\section{References}

1. Energy Efficiency \& Renewable Energy, Alternative Fuels \& Advanced Vehicles Data Center http://www.afdc.energy.gov/afdc/. Accessed August 26, 2009

2. EIADOE/EIA-0384(2007) (2008) www.eia.doe.gov/emeu/aer/pdf/aer.pdf. Accessed September 30, 2009

3. U.S. Department of Energy, Hydrogen Program "Introduction to Hydrogen for Code Officials" http://www.hydrogen.energy.gov/code_official_training.html. Accessed September 30, 2009

4. U.S. Department of Energy, Hydrogen Program "Permitting Hydrogen Facilities" http://www.hydrogen.energy.gov/permitting/stations_related.cfm. Accessed September 30, 2009

5. American National Standards Institute (ANSI)"Standardization" Standards Activities Overview, http://www.ansi.org/standards_activities/overview/overview.aspx. Accessed August 26, 2009

6. Lemoff, T. Private Telephone Communication, National Fire Protection Association (NFPA), August 009

7. Propane Education \& Research Council "Fleet." Trades, http://www.propanecouncil.org/Fleet.aspx?id=3316, Accessed August 24, 2009

8. Energy Efficiency \& Renewable Energy, "Propane." Alternative Fuels \& Advanced Vehicles Data Center, http://www.afdc.energy.gov/afdc/fuels/propane.html. Accessed August 24, 2009

9. NFPA 58, the Liquefied Petroleum Gas Code

10. Propane Education \& Research Council http://www.propanecouncil.org/newstemplate.aspx?id=4314. Accessed August 24, 2009

11. Union Gas Limited "History of Natural Gas Vehicles." Natural Gas for Vehicles, http://www.uniongas.com/aboutus/aboutng/ngv/ngvhistory.asp. Accessed September 30, 2009

12. International Association for Natural Gas Vehicles (IANGV) "Natural Gas Vehicle Statistics." http://www.iangv.org/tools-resources/statistics.html. . Accessed May 2008 
13. Energy Efficiency \& Renewable Energy, "Natural Gas." Alternative Fuels \& Advanced Vehicles Data Center, http://www.afdc.energy.gov/afdc/fuels/natural_gas.html. Accessed September 30, 2009

14. FuelMaker/Honda; http://science.howstuffworks.com/earth/greentechnology/sustainable/home/home-refueling-appliance.htm/printable

a. NOTE: the product line has been sold by FuelMaker to Fuel Systems Solutions, Inc and WEB information is being updated http://www.fuelmaker.com/

b. Accessed August 27, 2009

15. ISO 14469-2:2007 Road vehicles - Compressed natural gas (CNG) refuelling connector; ISO 15500: Road vehicles -- Compressed natural gas (CNG) fuel system components; ISO 11439 Gas cylinders - High pressure cylinders for the on-board storage of natural gas as a fuel for automotive vehicles

16. United Nations Economic Commission for Europe, "Global Technical Regulation No. 4 (WHDC)." http://www.unece.org/trans/main/wp29/wp29wgs/wp29gen/wp29registry/gtr4.ht ml. Accessed September 30, 2009

17. UL558: Industrial Trucks, Internal Combustion Engine-Powered

18. NFPA 505: Fire Safety Standard for Powered Industrial Trucks Including Type Designations, Areas of Use, Conversions, Maintenance, and Operations http://www.nfpa.org/aboutthecodes/AboutTheCodes.asp?DocNum=505\&cookie\%5Ftest=1

19. Energy Efficiency \& Renewable Energy, "What is biodiesel?" Alternative Fuels \& Advanced Vehicles Data Center, http://www.afdc.energy.gov/afdc/fuels/biodiesel_what_is.html. Accessed August 24, 2009

20. U.S. Environmental Protection Agency, "Biodiesel." SmartWay Grow \& Go, http://www.epa.gov/smartway/growandgo/documents/factsheet-biodiesel.htm. Accessed August 24, 2009

21. National Biodiesel Board, "Estimated US Biodiesel Production by Fiscal Year (Oct 1 - Sept 30)." Biodiesel Production Estimates FY99 - current. http://www.biodiesel.org/pdf_files/fuelfactsheets/Production_graph_slide.pdf. Accessed August 24, 2009

22. Energy Efficiency \& Renewable Energy, "Biodiesel Fueling Station Locations." Alternative Fuels \& Advanced Vehicles Data Center, http://www.afdc.energy.gov/afdc/fuels/biodiesel_locations.html. Accessed September 30, 2009 
23. NFPA 30, "The Flammable and Combustible Liquids Code"

24. NFPA 30A" The Code for Motor Fuel Dispensing Facilities and Repair Garages"

25. McCormick, R. Private Communication, National Renewable Energy (NREL), NREL, July 2009

26. Zimmer, J. Private Communication, Larry H. Miller Volkswagen, Denver, Colorado, July 2009

27. Energy Efficiency \& Renewable Energy, "E85 Fueling Station Locations." Alternative Fuels \& Advanced Vehicles Data Center, http://www.afdc.energy.gov/afdc/ethanol/ethanol_locations.html. Accessed September 30, 2009

28. Change2E85.com, "E85 Ethanol Myths." http://www.change2e85.com/servlet/Page?template=Myths. Accessed August 24, 2009

29. American Coalition for Ethanol, http://www.ethanol.org/video/, Accessed August 24,2009

30. Energy Efficiency \& Renewable Energy, "Intermediate Ethanol Blend Research." Alternative Fuels \& Advanced Vehicles Data Center, http://www.afdc.energy.gov/afdc/ethanol/blends_e15_e20_research.html, Accessed August 24, 2009

31. Horne, D. Private Communication, Clean Vehicle Education Foundation, NREL, August 2009

32. Knoll, K. Private Communication, National Renewable Energy (NREL), NREL, July 2009

33. Smith, R. Private Communication, Compressed Gas Association (CGA), NREL, August, 2009

34. California Fuel Cell Partnership, http://www.fuelcellpartnership.org/. Accessed September 30, 2009

35. Energy Efficiency \& Renewable Energy, "Hydrogen Fuel”, Alternative Fuels \& Advanced Vehicles Data Center http://www.afdc.energy.gov/afdc/fuels/hydrogen.html, Accessed September 30

36. Asebe, T. Private Communication, Department of Transportation (DOT) Office of Pipeline Safety, August, 2009 
37. About.com, "The History of Electric Vehicles." Inventors, http://inventors.about.com/library/weekly/aacarselectric1a.htm. Accessed September 30, 2009

38. "IEEE P1635 and ASHRAE/D3 Draft Guide for the Ventilation and Thermal Management of Batteries for Stationary Applications" The Institute of Electrical and Electronics Engineers, Inc, (2009). 


\section{APPENDIX I:}

\section{Biographies (in alphabetical order):}

\section{Chad Blake}

Senior Project Leader, National Renewable Energy Laboratory (NREL)

Chad Blake is a Senior Project Leader in the Codes and Standards Group of the Vehicle Technologies Program at NREL in Golden, CO. He has worked at several U.S. Department of Energy (DOE) laboratories for 15 years in nuclear, energy, government, operations, and research environments. He joined the staff at NREL in 2007 and currently leads codes and standards hydrogen fuel quality efforts as well as $\mathrm{R} \& \mathrm{D}$ on other renewable transportation fuels. He is a member of the International Energy Agency's Task 19, the DOE Hydrogen Safety Panel, and several codes and standards related committees.

\section{William Buttner, Ph.D.}

Senior Scientist I, National Renewable Energy Laboratory (NREL)

Dr. William Buttner is a member of the Vehicle Codes and Standards Group at NREL in Golden, CO. As a member of the Codes and Standards Group, Dr. Buttner has been active in the safe implementation of alternative fuels for vehicle applications, with an emphasis on hydrogen. He has been active in the design and construction of the Hydrogen Sensor Laboratory at NREL. Dr. Buttner is also active in a variety of standards development organizations including ISO, IEEE, and UL Dr. Buttner is a member of the Electrochemical Society, and serves on the Chemical Sensor Group. Dr. Buttner has a Ph.D. in chemistry from Michigan State University and has over 25 years experience in chemical and physical sensor technology, field analytical chemistry, and electrochemical processes. 
Biographies (in alphabetical order):

\section{Larry Fluer}

Fluer, Inc.

Larry Fluer is a Technical Consultant and Principal of Fluer, Inc., a firm specializing in the safe handling and use of hazardous materials in technical buildings and facilities where the safety of employees and the public are of particular concern. The firm was founded by Larry Fluer in 1979 to provide professional counsel and guidance in this highly specialized field. Educated as a chemist, Fluer has held technical, supervisory and safety responsibilities in various military and industrial organizations involved with the proper handling of such materials.

Fluer is a recognized expert in the area of building and life safety where he applies his experience and knowledge to code interpretation, analysis and development, and to hazard evaluation as it relates to today's processes in buildings and other facilities where the safety of employees and the public are paramount. Fluer has served as an independent contractor and advisor to building departments, fire departments, building owners, building designers and others. He has provided consulting services and served as an expert witness for attorneys in matters involving the storage and use of compressed gases and other hazardous materials.

He participates both as a professional advocate and a volunteer, in the development of building codes, fire codes and safety standards through membership in various standards and technical organizations, including the model codes and standards development organizations. Fluer's expertise in code matters related to hazardous materials is recognized by those involved in the code development process as well as those in the code application and enforcement community. 
Biographies (in alphabetical order):

\section{Douglas B. Horne}

P.E., President, Clean Vehicle Education Foundation

President, DBHORNE LLC

Chairman, NFPA 52

Director of Research and Development, Atlanta Gas Light Company

Director of Business Process Development, Atlanta Gas Light Company

Founder of NGVC Technology Committee, the RD\&D Initiative

As president of the Clean Vehicle Education Foundation (CVEF), Douglas Horne draws on long experience in the alternative fuels industry. When Horne began his career in the energy industry in the late 1960's, one of his first assignments was to work with a utility fleet in developing and LNG fleet and later transition that fleet to Propane fuel then to CNG. As a member of the Advanced Technology Task Force of the AGA Technology Committee, Doug participated in founding the NGVC now NGV America. Horne, as Director of R\&D at Atlanta Gas Light, worked in a lead role, both nationally and internationally, on the development of alternative fuel vehicle technology and codes and standards. He served as long time Chairman of NFPA 52 \& 57, the NGVC Technology Committee, the RD\&D Initiative, the Gas Utilization Research Forum and many other groups over the years.

In 2002, Horne took early retirement and formed DBHORNE LLC to provide alternative fuel technology management services. DBHORNE LLC has clients from the Philippines to Israel and primarily provides consulting services to various national laboratories and the alternative fuel industry internationally. He is a consultant to the National Renewable Energy Laboratory (NREL) and the U.S. Department of Energy on biofuel technology and codes and standards including working with Underwriters Laboratory (UL) on listing procedures for E85 dispensers and related equipment. As part of that effort Horne chairs the Society of Automotive Engineers T\&B Alternative Fuel Subcommittee as is presently developing a new recommended practice for Flex Fuel Vehicles. The CVEF has contracted with DBHORNE LLC for Horne to serve as president of the foundation.

\section{Keith Knoll}

Senior Project Leader in the Fuels Performance group of NREL's Center for Transportation Technologies and Systems, U.S. Department of Energy's National Renewable Energy Laboratory (NREL) Colorado 
Biographies (in alphabetical order):

Theodore Lemoff, P.E.

After graduating from the City College of New York with a Bachelor of Engineering (Chemical) degree, Theodore C. Lemoff was employed in the chemical and petrochemical industry by Proctor and Gamble Company, Sun Chemical Corporation, and Badger Engineers, Inc., in various engineering positions. He joined NFPA in 1985 and currently serves as NFPA's principal gases engineer. He serves as NFPA staff liaison to the National Fuel Gas Code Committee, and he is also responsible for other NFPA standards on flammable gases.

In addition to being the editor of the, Lemoff is the editor of the LP-Gas Code Handbook, the National Fuel Gas Code Handbook ,and co-author of the NFPA Pocket Guide to Fuel Gas Storage and Use.

Lemoff represents NFPA on the ASME Code for Pressure Piping Committee (National Interest Review Group) (B31), the pipeline safety advisory committee of the U.S. Department of Transportation, and the IAPMO Mechanical and Plumbing Code Committees.

Lemoff is a registered professional engineer in the Commonwealth of Massachusetts and is a member of the American Institute of Chemical Engineers and the Society of Fire Protection Engineers, the Society of Gas Engineers, and the International Association of Plumbing and Mechanical Officials.

\section{Dr. Robert L. McCormick}

Principal Engineer, U.S. Department of Energy's National Renewable Energy Laboratory (NREL)

Colorado

Bob McCormick is Principal Engineer in the Fuels Performance Group at NREL. He attended Oklahoma State University, Iowa State University, and the University of Wyoming, holds a doctorate in chemical engineering, and has worked in fuel processing, catalysis, and fuel utilization $\mathrm{R} \& \mathrm{D}$ for 18 years in both industrial, academic, and government environments. He joined the staff at NREL in 2001 and currently leads biodiesel utilization R\&D as well as R\&D on other renewable transportation fuels. Dr. McCormick has engaged in R\&D on biodiesel utilization for more than 10 years. 
Biographies (in alphabetical order):

\section{Dr. Roland Pitts}

Co-Inventor On the Licensed Technology and Principal Investigator

National Renewable Energy Laboratory (NREL)

Research Scientist

Planar Energy Devices Inc.

Roland Pitts is a Senior Scientist and leader of the Optoelectronics Team in the Center for Basic Sciences

Roland Pitts is Planar Energy Devices' Chief Science Officer and founding research scientist (2007-date). He has helped assemble a world-class team of researchers and engineers to develop the innovative battery structures that will bring transformational energy storage devices to market. During his 29-year career at NREL, he performed research activities in a breadth of areas of interest to energy efficiency and renewable energy. He was a Senior Scientist and leader of the Optoelectronics Team (1999-2007) and in the Center for Basic Sciences (1996-2007), the Measurement and Characterization Branch of the National Center for Photovoltaics (1989-1996), and the Materials Research Branch (1978-1989). Dr. Pitts has contributed to a wide array of projects, spanning the major areas of research at the laboratory. His principal areas of expertise are in solid-state physics, materials science, and surface and interface studies of thin films. He most recently worked on solid-state lithium batteries, dynamically controlled glazings for high-performance windows, fiber-optic-based hydrogen sensors, and materials synthesis in extreme environments. [info from http://www.planarenergy.com/Company_Management.html]

Carl Rivkin, P.E.

Senior Project Leader II, National Renewable Energy Laboratory (NREL)

Mr. Rivkin is the project leader for the Codes and Standards Project team at NREL in Golden, CO. The Codes and Standards Group at NREL has responsibility for implementing the U.S. National Template of Codes and Standards for alternative fuels for vehicles. This implementation effort runs the gamut from running a sensor test laboratory to evaluate the performance of chemical sensors to conducting codes and standards seminars to assist code officials in permitting facilities.

Rivkin has over 25 years of experience in safety and environmental engineering including work at a regulatory agency. Prior to joining NREL, Rivkin worked for the National Fire Protection Association on alternative energy code projects. He was also the editor of "The NFPA Guide to Gas Safety," published in 2005, which has several chapters devoted to hydrogen and flammable gas safety.

Rivkin has a bachelor's degree in chemical engineering from the University of Michigan and an MBA from the University of Baltimore. He is a licensed Professional Engineer (P.E.) and Certified Safety Professional (CSP). 
Biographies (in alphabetical order):

\section{Dr. Christine Sloane}

Sloane Solutions, LLC

Christine Sloane retired from General Motors in 2008 and is continuing to work on hydrogen safety issues through her company Sloane Solutions, LLC.

Dr. Sloane led General Motor's global team for hydrogen and fuel cell vehicle Codes and Standards development. She coordinates development of GM policy and technical strategy across safety, engineering and public policy requirements and ensures global consistency in GM interaction with government and professional industry organizations. She previously directed the GM interaction with the U.S. FreedomCAR program, which included R\&D to advance fuel cell power systems, and earlier served as chief technologist for the development and demonstration team for Precept, GM's 80 mile-per-gallon 5-passenger HEV concept vehicle.

She has also been responsible for global climate issues and for mobile emission issues involving advanced technology vehicles. Her early research interests included air quality, and manufacturing \& vehicle emissions. Dr. Sloane has authored over 80 technical papers and co- edited one book. She has served on several boards of professional organizations and numerous National Academy of Science panels and study groups. She received her $\mathrm{PhD}$ from MIT in chemical physics.

\section{Roger Smith}

Technical Director Compressed Gas Association

Roger Smith is Technical Director for the Compressed Gas Association (CGA) and has served in that position for 13 years. Prior to joining CGA, Smith spent 25 years in the industrial and medical gas industry in operations. Industry experience includes the management of single and multi-site manufacturing operations, facility engineering, quality assurance, transportation, purchasing and research and development.

Smith joined CGA in April 1996 as Technical Director and is responsible for directing the technical operations of the Association and also reviews and approves all technical documents produced by the Association.

In addition to his duties as Technical Director, Smith is responsible for CGA's international activities at the United Nations and the International Organization for Standardization (ISO). He is Chairman of ISO/TC 58/SC 4 which develops and manages the standards for operational requirements for gas cylinders.

Smith has a B.S. in Chemistry from Rutgers University, New Brunswick, New Jersey. 
Biographies (in alphabetical order):

\section{E. Michael Steele}

E. Michael Steele has been involved in the development of both electric- and hydrogen-vehicle/infrastructure related Codes and Standards for General Motors for the last 10 years. Steele is currently Chair of the SAE Fuel Cell Standards Committee responsible for developing vehicle-centric engineering Standards. He is a Principal member of two NFPA Code Panels (2 and 52) as well as an active member of numerous ISO TC 197 and TC22SC21 working groups. Steele also participates in several CSA America technical working groups striving to complete a comprehensive set of hydrogen Standards that will greatly assist in the international commercialization of hydrogen-based transportation systems. 


\section{APPENDIX II}

Evaluation of Codes and Standards for Electric and Plug-In Vehicles

(an independent assessment)

(used with permission) 


\title{
Evaluation of Codes and Standards for Electric and Plug-In Vehicles
}

Presented to the National Renewable Energy Laboratory (NREL)

\author{
By Mark Kosowski
}

September 2, 2009 


\section{Contents}

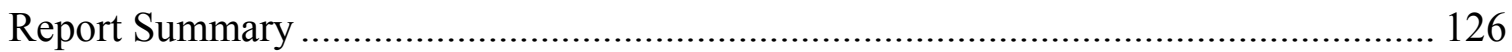

SAE J-1634: Electric Vehicle Energy Consumption and Range Test .......................... 127

SAE J-1711: Recommended Practice for Measuring the Exhaust Emissions and Fuel economy of Hybrid-Electric Vehicles ..................................................................... 128

SAE J-1715: Hybrid Electric Vehicle (HEV) and Electric Vehicle (EV) Terminology

SAE J-1766: Recommended Practice for Electric and Hybrid Electric Vehicle Battery

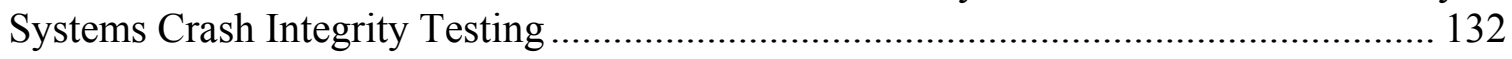

SAE J-1772: SAE Electric Vehicle Conductive Charge Coupler.................................. 134

SAE J-1773: SAE Electric Vehicle Inductively-Coupled Charging............................. 137

SAE J-1797: Recommended Practice for Packaging of Electric Vehicle Battery Modules

SAE J-1798: Recommended Practice for Performance Rating of Electric Vehicle Battery

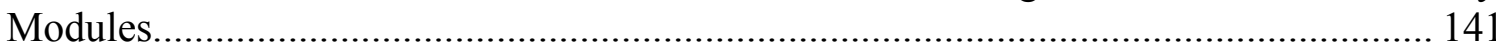

SAE J-1850: Class B Data Communications Network Interface.................................... 143

SAE J-2288: Life Cycle Testing of Electric Vehicle Battery Modules .......................... 144

SAE J-2289: Electric-Drive Battery Pack System: Functional Guidelines .................... 145

SAE J-2293 Part 1: Energy Transfer System for EV Part 1: Functional Requirements and

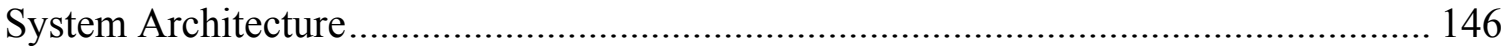

SAE J-2293 Part 2: Energy Transfer System for EV Part 2: Communications

Requirements and Network Architecture.................................................................... 149

SAE J-2344: Guidelines for Electric Vehicle Safety ................................................. 150

SAE J-2380: Vibration Testing of Electric Vehicle Batteries ........................................ 153

SAE J-2464: Electric and Hybrid Electric Vehicle Rechargeable Energy Storage System (RESS) Safety and Abuse Testing .............................................................................. 154

SAE J-2711: Recommended Practice for Measuring Fuel Economy and Emissions of

Hybrid-Electric and Conventional Heavy Duty Vehicles.............................................. 158

SAE J-2758: Determination of the Maximum Available Power from a Rechargeable Energy Storage System on a Hybrid Electric Vehicle ................................................... 159

SAE J-2836 Part 1: Use Cases for Communications between Plug-In Vehicles and the

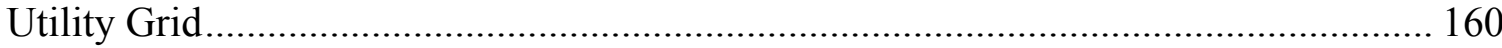

SAE J-2836 Part 2: Use Cases for Communications between Plug-In Vehicles and the

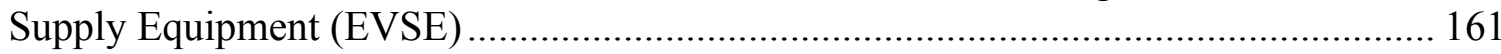

SAE J-2836 part 3: Use Cases for Communications between Plug-In Vehicles and the

Utility grid for Reverse Flow ................................................................................... 162

SAE J-2841: Utility Factor Definitions for Plug-In Hybrid Electric Vehicles Using 2001

U.S. DOT National Household Travel Survey Data..................................................... 163

SAE J-2847 Part 1: Communications between Plug-In Vehicles and the Utility Grid . 165

SAE J-2847 Part 2: Communication between Plug-in Vehicles and the Supply

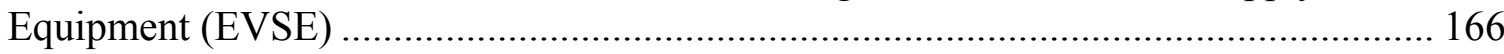

SAE J-2847 Part 3: Communication between Plug-in Vehicles and the Utility Grid for

Reverse Power Flow 
SAE J-2889: Measurement of Minimum Sound Levels of Passenger Vehicles

SAE J-2894 Part 1: Power Quality Requirements for Plug-In Vehicle Chargers -

Requirements

SAE J-2894 Part 2: Power Quality Requirements for Plug-In Vehicle Chargers - Test

Methods.

SAE J-2907: Power Rating Method for Automotive Electric Propulsion Motor and

Power Electronics Sub-System

SAE J-2908: Power Rating Method for Hybrid-Electric and Battery Electric Vehicle

Propulsion

ISO/FDIS 6469-1:2009(E): "Electrically propelled road vehicles - Safety specification -

Part 1: On-board rechargeable energy storage system (RESS)"

ISO/FDIS 6469-2:2009(E): "Electrically propelled road vehicles - Safety specification -

Part 2: Vehicle Operational Safety Means and Protection against Failures"....

ISO/CD 6469-3.3: "Electrically propelled road vehicles - Safety specification - Part 3:

Protection of persons against electric shock"

ISO/CD 12405-1: "Electrically propelled road vehicles - Test specification for lithiumion traction battery packs and systems - Part 1 "High power applications"

ISO/WD 23274-2: "Hybrid-electric road vehicles - Exhaust emissions and fuel

consumption measurements - Part 2: Externally chargeable vehicles"

ISO XXX "Terminology Technical Report".

National Fire Protection Agency (NFPA) NFPA 70 National Electrical Code (NEC)

Article 625: Electric Vehicle Charging System Equipment

National Fire Protection Agency (NFPA) NFPA 70 National Electrical Code (NEC)

Article 626: Electrified Truck Parking Spaces 


\section{Report Summary}

This report evaluates 38 standards or articles pertaining to electric or plug-in hybrid vehicles from Society of Automotive Engineers (SAE), International Standards Organization (ISO), and the National Electrical Code (NEC). These standards were selected due to the plug-in and electric vehicle nature of them. The standards include battery topics, charging and interface topics, hybrid and electric terminology, fuel economy and exhaust emissions for plug-in hybrids and electric vehicles, electric vehicle safety, fuel economy utility factor definitions, power quality for chargers, power ratings for motors and electronics, power ratings for batteries. Other generic standards, some referenced in these documents, were not evaluated in this report (i.e., general fuel economy, electromagnetic compatibility).

Each evaluation is formatted with the title, status, overview, analysis, and location of the document. The status contains the date of the last publication along with the length of the document with the number of pages. The overview is a short synopsis of the document; if more detail is required the document should be referenced. The analysis provides the author's remarks and gap analysis of the document. If the document is a Work In Progress (WIP), the changes are listed here. Finally, the website location of the document is listed, if applicable.

This report is assembled for the National Renewable Energy Laboratory (NREL). Carl Rivkin is the technical monitor. This "Evaluation of Codes and Standards for Electric and Plug-In Vehicles" is performed and written by Mark Kosowski, Consultant under Purchase Order \#191730 on September 2, 2009. 


\section{SAE J-1634: Electric Vehicle Energy Consumption and Range Test}

\section{Status:}

Cancelled: October 2002

Issued: October 2002

\section{Overview:}

This Recommended Practice established uniform procedures for testing electric battery-powered vehicles which are capable of being operated on public and private roads. The procedure was only for electric vehicles.

This document was under the auspices of the Light Duty Vehicle Performance and Economy Measure Committee

Document Location:

http://www.sae.org/servlets/productDetail?PROD TYP=STD\&PROD CD=J1634 \&HIER CD=TEVLDVPM\&WIP SW=YES 


\section{SAE J-1711: Recommended Practice for Measuring the Exhaust Emissions and Fuel economy of Hybrid-Electric Vehicles}

\section{Status:}

WIP official ballot in August 2009

Issued March 1999 (Original) and 69 pages in length

\section{Overview:}

This overview is an overview of the March 1999 document. The Analysis section indicates the major differences between the original document and the WIP document.

This Recommended Practice establishes uniform chassis dynamometer test procedures for hybrid-electric vehicles that are designed to be driven on public roads. The procedure provides instructions for measuring exhaust emissions and fuel economy of HEVs driven on the Urban Dynamometer Driving Schedule (UDDS) and fuel economy on the Highway Fuel Economy Schedule (HFEDS), as well as exhaust emissions on the US06 Schedule and the SC03 Schedule. This document consists of three basic steps: 1. Classifying the hybrid-electric vehicle and 2. Testing the vehicle in each driver-selected operating mode, and 3. Weighting the results.

1. It is first required that vehicle be classified as a "Off-Vehicle Charge" or "Not Off-Vehicle Charge". Then the type of Rechargeable energy storage is required to be determined (battery, capacitor, flywheel...).

2. Testing the vehicle next as a Conventional Vehicle (CV), Hybrid-Electric vehicle (HEV), or Electric Vehicle (EV)

3. Finally, the results of the tests are weighted to account for the driver's charging habits, usage of various selected operating modes, and other factors as applicable.

Test procedures are defined.

1. Test conditions are defined including Vehicle Conditions, Dynamometer Conditions, and Rechargeable Energy Storage System Conditions.

2. Test Instrumentation is defined including Amp-hour meters.

3. Exhaust Emissions and Fuel Economy Tests
a. Partial-Charge Test for HEV (PCT-HEV) 

b. Full-Charge Test for HEV (FCT-HEV)
c. Partial-Charge Test for CV (PCT-CV)
d. Full-Charge test for EV (FCT-EV)

4. Calculations with weighting factors are defined for Emissions and Fuel Economy for many combinations of hybrids and EVs.
a. Urban Dynamometer Driving Schedule (UDDS)
b. Highway Fuel Economy Driving Schedule (HFEDS)
c. US06 Driving Schedule (US06)
d. SC03 Driving Schedule (SC03)
e. The Utility Factor is defined as a function of distance driven in all electric mode.

\section{Analysis:}

The 1999 version of this document is defined above and is presently being updated. The document balloting is occurring in August 2009.

The new document has many improvements over the original document. The original document only provided a single fuel economy datum and ignored the usage of electric power from the wall. The new edition will suggest using two data points for fuel economy, one is fuel economy for the liquid fuel (like the original) and the other point will be the electric fuel consumption from the wall including charger efficiency. This provides a complete status of the energy use for the customer. However, work needed to be complete that indicated how to measure the electrical energy.

The original document provided a Utility Factor but only a single factor that was used for the UDDS and the HFEDS. SAE J-2841 Utility Factor Definitions for Plug-In Hybrid Electric Vehicles Using 2001 U.S. DOT National Household Travel Survey Data defines a new Utility Factor which was based from the same initial data only the data was sorted into urban usage and highway usage. The original document made the assumption that the vehicle was only charged every other day. The new document now assumes the vehicle is charged daily. The frequency of charging was increased.

The committee is still working an issue for the charge balancing. The committee plans on proceeding with an informal ballot in early October 2009. The document is expected to be complete and balloted by the end of 2009 . 
Document Location:

http://www.sae.org/servlets/works/documentHome.do?comtID=TEVHYB\&docID= J1711 199903\&inputPage $=$ dOcDeTallS 


\section{SAE J-1715: Hybrid Electric Vehicle (HEV) and Electric Vehicle (EV) Terminology}

\section{Status:}

WIP in progress August 2009

Revised: February 2008 and 22 pages in length

Issued: April 1994 (Original)

\section{Overview:}

This Information Report is an on-going effort to provide the technical community with the terminology used most frequently in the industry. This document contains definitions for Hybrid Electric and Electric Vehicles. It is intended to be a resource for other documents, specifications, and standards.

The document is divided into three main sections, Electric Vehicles, Hybrid Electric Vehicles, and Functional Architecture Diagrams. The Electric Vehicle section has 145 definitions. There are definitions for batteries, battery parameters, efficiency, throughput, and many more.

The Hybrid Electric Vehicle section includes hybrid definitions. This section has 18 definitions including Parallel Hybrid, Series Hybrid, and Vehicle to Grid Connection (V2G).

The third major section is the Functional Architecture Diagrams. This section shows many different architectures and how they are defined. Schematics and Definitions for Power-split with single mode and 2-mode are provided. The difference between parallel and series hybrids are shown. The use of clutches is shown with different schematics.

\section{Analysis:}

The original document was mainly contented with Electric Vehicles. Overtime technologies improve and are modified; the most recent update includes those changes and many hybrid definitions and hybrid schematics.

Presently, there is a group updating the document, particularly for harmonization with the new J-1772 Electric Vehicle Conductive Charge Coupler and the Range-Extended Electric Vehicle (REEV) nomenclature.

The new document should be completed and balloted in the fall of 2009 .

\section{Document Location:}

http://www.sae.org/servlets/works/documentHome.do?comtID=TEVHYB\&docID= J1715 200802\&inputPage $=$ dOcDeTallS 


\title{
SAE J-1766: Recommended Practice for Electric and Hybrid Electric Vehicle Battery Systems Crash Integrity Testing
}

\section{Status:}

Revised: April 2005 and 16 pages in length

Issued: February 1996

\section{Overview:}

This Recommended Practice describes methods for evaluating the vehicle high voltage system performance when subjected to various FMVSS crash procedures. It addresses the following subjects: battery retention, electrical isolation, and electrolyte spillage. It is intended to provide designers with standard tests and performance criteria for electric, fuel cell, and hybrid vehicles. It is pertinent for any vehicle that has a high voltage potential.

The standard discusses adequate barriers between occupants and the high voltage systems are necessary. These barriers provide protection from harmful electric current within the high voltage system that can cause injury to occupants during a crash event.

The rationalization is made up of four items- Time, Voltage, Isolation, and Energy. If three of these are low, then the fourth can be quite high and not result in a hazard. Body Current diagrams are shown in regards to energy, time, and voltage, thus showing the potential hazardous limits.

This Recommended Practice addresses the technical requirements for the procedures:

\author{
Energy Storage Preparation \\ Static Rollover Procedure \\ Crash Test Procedures \\ Performance Criteria are defined: \\ Electrolyte Spillage \\ Energy Storage System Retention \\ Electrical Limits \\ Voltage Limits \\ Isolation Limits \\ Energy Limits
}

Appendix A of the Recommended Practice contains the procedure for the measurement of the electrical isolation

\section{Analysis:}

This Recommended Practice encourages experienced users and testers of such systems to write comments and/ or suggestions to SAE. 
The paper describes the procedure but does not expound on the theory of why the procedures work. This is not necessary.

The standard presents very good design guidelines for isolation safety.

Document Location:

http://www.sae.org/technical/standards/J1766 200504 


\section{SAE J-1772: SAE Electric Vehicle Conductive Charge Coupler}

\section{Status:}

WIP August 2009 (To be balloted in September if passed should be published in early fall 2009)

Revised: November 2001 and 32 pages in length

Issued: October 1996 (Original)

\section{Overview:}

This overview is an overview of the November 2001 document. The Analysis section indicates the major differences between the original document and the WIP document.

This document describes the functional and performance requirements for proper operation and the physical interface for a conductive charging system. This Recommended Practice is intended as a guide toward standard practice and is subject to change to keep pace with experience and technical advances.

This document covers the physical, electrical, and performance requirements for the electric vehicle conductive charge system and coupler for use in North America.

The General Conductive Charging System descriptions includes three functions- 1) Convert AC Power to DC (rectification), 2) Control the Supply Voltage, and 3) Physical Coupling of the EV to the Electric Vehicle Supply Equipment (EVSE). This conductive system architecture is suitable for the electrical ratings shown below.

Charging Method is described as the interface from the vehicle to the coupler.

\begin{tabular}{|c|c|c|c|c|}
\hline $\begin{array}{l}\text { Charge } \\
\text { Method }\end{array}$ & $\begin{array}{l}\text { Nominal Supply } \\
\text { Voltage }\end{array}$ & $\begin{array}{l}\text { Max } \\
\text { Current }\end{array}$ & $\begin{array}{l}\text { Branch Circuit } \\
\text { Breaker } \\
\text { Rating }\end{array}$ & $\begin{array}{l}\text { Charger } \\
\text { Location }\end{array}$ \\
\hline $\begin{array}{l}\text { AC Level } 1 \\
\text { AC Level } 2 \\
\text { DC Charging }\end{array}$ & $\begin{array}{l}120 \text { V AC, } 1 \text { phase } \\
208 \text { to } 240 \text { V AC, } 1 \text { Phase } \\
600 \text { V DC Max }\end{array}$ & $\begin{array}{l}12 \mathrm{~A} \\
32 \mathrm{~A} \\
400 \mathrm{~A} \text { Max }\end{array}$ & $\begin{array}{l}15 \mathrm{~A} \mathrm{Min} \\
40 \mathrm{~A} \\
\text { As Required }\end{array}$ & $\begin{array}{l}\text { On-Board Vehicle } \\
\text { On-Board Vehicle } \\
\text { Off-Board Vehicle }\end{array}$ \\
\hline
\end{tabular}

Interface Functions are defined. There are 9 interface connections to be made including AC Power (L1), AC Power (L2), DC Power Positive, DC Power Negative, Equipment Ground, Control Pilot, Data Positive, Data negative, and Data ground. Schematics are assigned for AC Level 1 and Level 2 Charging and DC Charging.

Control and Data are defined. The Control Pilot Circuit is shown with all its components. The Control Pilot functions are defined. Proximity detection is 
shown and the Serial Data transfer specifications are shown. The EVSE current capacity versus control pilot pulse width is shown. Typical start-up sequencing is provided.

General EV requirements are stated and defined. These include electromagnetic compatibility, electromagnetic emissions, electromagnetic immunity, electrostatic discharge, and environmental.

General EVSE requirements are provided. These include installation requirements, product standards, personnel protection systems, conductor cord requirements, coupler requirements, and electromagnetic compatibility.

Coupler requirements are also provided. These include vehicle inlet and coupler compatibility, ergonomic requirements, safety requirements, performance requirements, environmental requirements, general coupler physical description, dimensional requirements.

\section{Analysis:}

- The latest copy of the Work-in-Progress is August, 2009

- The document should go to ballot in early September, 2009

- The published date should be in the early fall of 2009

- The primary changes to the latest document are:

- The physical design is now a pin and sleeve configuration and not a butt contact

- The control pilot now has been changed to a maximum of $80 \mathrm{~A}$ up from $40 \mathrm{~A}$

- The proximity sense now a $\mathbf{5 V}$ reference for OBD II diagnostics

- EMC requirements have been updated

- The original butt contact requirements have been placed into an appendix.

- The EVSE current capacity versus control pilot pulse width function has changed from the original document.

- Communications signals and terminals for the J-1850 Practice have been eliminated from the connector which obsoletes J-1850.

- Several manufacturers are or will be capable of making compatible hardware including Yazaki, Lear, and Amphenol. 
- The IEC has a small issue with the document. The IEC would like to see a latching mechanism that is controlled by the vehicle side. This is different than this document which allows for a latching mechanism on the EVSE side. Wording for harmonization later will be added to this document to get around the issue now.

- The original butt and contact coupler had 9 pins, the new pin and sleeve coupler only required 5 pins.

- Level 3 DC standards committee is just beginning to meet. The Level 3 Specification will be added to the J-1772 Recommended Practice at a later date. The chargers for level 3 are now being bench marked to fully understand the hardware so that harmony can be reached. A face-to-face meeting is planned for October 2009 to first define the system and then define the connection.

- The new coupler is not compatible with Level $3 \mathrm{DC}$ connector like the original coupler was. Therefore, an application which will use both high power charging and lower power charging will require to have at least two connections, a Level 1,2 connector and a level 3 connector, on the vehicle.

\section{Document Location:}

The 2001 document is located:

http://www.sae.org/servlets/works/documentHome.do?comtID=TEVHYB\&doclD= $\underline{J 1772 \text { 200111\&inputPage }=\text { dOcDeTallS }}$ 


\section{SAE J-1773: SAE Electric Vehicle Inductively-Coupled Charging}

\section{Status:}

Reaffirmed: May 2009 and 35 pages in length

Reissued: November 1999

Issued: January 1995

\section{Overview:}

This document establishes the minimum interface compatibility requirements for electric vehicle inductively-coupled charging for North America. The first part of this document is the specification for manually-connected inductive charging for levels 1 and 2 power transfer. Appendix $B$ has the requirements for Level 3 (high power) Inductive Charging. Appendix A contains the recommended software interface messaging requirements. This document is an alternative charging method to the Conductive Charge Coupler (SAE-J1772).

An inductive charging system interfaces to the vehicle as a primary coil of a transformer. Most of the charging system is off-board the vehicle. Only the second half of the transformer and the rectifiers are on-board the vehicle. The charger transforms wall power into a frequency-controlled current. This frequency-controlled current is fed into the inductive coupler (primary coil of the transformer). When the coupler is placed into the transformer on the vehicle and the charging is enabled, the current is passed through the coupler into the transformer and then rectified into the on-board battery.

There is communications passed to and from charger and the vehicle via a J1850 standard.

This document expresses the minimum interfaces needed for the system including Power Transfer, Heat Transfer, Communications, Physical Compatibility, and Electromagnetic Emissions. Application requirements are discussed including Environmental, Charger and Vehicle Requirements.

The second document in 1999 improved on the original by including a second smaller interface. The smaller interface, however, does not comprehend the use of the Level 3 coupler which requires a larger envelope like the original coupler. The latest document just reaffirmed the same as the 1999 document.

\section{Analysis:}

The Inductive method is shown in this document places the charger off the vehicle for all power levels above 1.0kW charging. Locating the charger off the vehicle allows the vehicle more packaging space for other considerations. The vehicle is only required to have a partial transformer, rectifiers and filter. However, if the charger is not on the vehicle, then it is considered to be part of the infrastructure. 
The Conductive method (J-1772) places the charger always on the vehicle. With the charger on the vehicle, the vehicle manufacturer needs to make space for the charger. With Level 2 and beyond charging, the conductive method also requires a control box (EVSE) off the vehicle. This EVSE is part of the infrastructure. If the EVSE is a part of the infrastructure, then the charger should also be a part of the EVSE.

Unfortunately, the conductive method has won out in the market place, even though the inductive architecture is a far superior technology and architecture. The inductive has a common interface for all levels of charging, whereas the conductive will require two different interfaces on the vehicle for level 2 and level 3 charging.

The inductive document has recently been reaffirmed but virtually is obsolete since the market is not pulling the inductive method and no one is pushing it either.

Document Location:

http://www.sae.org/servlets/productDetail?PROD TYP=STD\&PROD CD=J1773 200905 


\section{SAE J-1797: Recommended Practice for Packaging of Electric Vehicle Battery Modules}

\section{Status:}

Reaffirmed: June 2008 and 23 pages in length

Issued: January 1997 (Original)

\section{Overview:}

This Recommended Practice was established to define a standardized method for packaging secondary battery modules for Electric Vehicles. Some of the incentives of this effort include component safety, compatibility, availability, and economics.

A procedure is included for acceptance of New SAE EV batteries.

Presently the procedure outlines the standard for the following:

- Product Description

- Three different aqueous batteries- Lead Acid, NiCd, and NiMH

- A single voltage level of nominal voltage of $12 \mathrm{~V}$

- Packaging envelops for four different modules including terminal dimensions and locations

- Capacity

- Mass

- Systems Interfaces

- Mechanical interfaces including module retention features

- High Power Connection requirements

○ Dielectrics

- Vented Emissions Interface including Flame arrestor and gaseous venting requirements

- High Power Electrical Interfaces

- Physical Pick-up Features Interface 
- Monitoring/ Control Interfaces including Voltage, Temperature, Thermal Management

- Marking and Label

○ Safety

- Polarity

- Information

○ Battery Module Designation

- Performance ratings

- Type of Electrochemistry

○ Recycling

- Manufacturer's Information

- Country of Origin

\section{Analysis:}

One of the key purposes for the standard was to create a standard module for an Original Equipment Manufacturer (OEM). A common physical shape assists the OEM so that it could easily replace a technology anytime now and into the future and not need extreme changes to the vehicle.

This procedure only includes commercially available aqueous batteries including Lead Acid, Nickel Cadmium, and Nickel Metal Hydride. The standard needs to be updated with new technologies such as Lilon and Sodium batteries. Presently, there is no action being taken to improve or include Lithium batteries in the document.

In the past, OEMs would meet together to understand and have consensus on battery requirements. Presently, much independent work is being completed but without harmony.

Document Location:

http://www.sae.org/servlets/works/documentHome.do?comtID=TEVHYB\&docID= J1797 200806\&inputPage=dOcDeTallS 


\title{
SAE J-1798: Recommended Practice for Performance Rating of Electric Vehicle Battery Modules
}

\author{
Status: \\ Reaffirmed: July 2008 and 16 pages in length \\ Issued: January 1997 (Original)
}

\section{Overview:}

This Recommend Practice provides direction for standardization of methods and techniques to verify and determine performance characteristics of the standard EV battery modules. It provides industry the opportunity to establish and maintain performance standards to meet vehicle requirements.

The procedures in this standard are for battery modules and not battery packs. Six different test procedures to determine performance are compiled. These test procedures and protocol are a Static Capacity Test with the Constant Current Method, a Static Capacity Test with the Constant Power Method, Charge Retention, Charge Acceptance, Peak Power Capability Test, and Dynamic Capacity Test. The test temperature will be performed at only one temperature $25^{\circ} \mathrm{C}$.

The Static Capacity Test with the Constant Current Method is to establish the Ampere-hour and energy capacity at various discharge rates and temperatures as appropriate to establish vehicle application usage. The test sequence is defined.

The Static Capacity Test with the Constant Power Method is similar to the Constant Current method except Constant Power is used. The test sequence is defined.

The Charge Retention Test is to determine the storage characteristics of a module after charge. The procedure is defined.

The Charge Acceptance Test determines how readily the module will accept charge at various temperatures. This is a complete charge test. The procedure is defined.

The Peak Power Capability Test determines the ability of the module to deliver sustained power for 30 seconds over its useable discharge capacity. The test sequence is defined along with the calculations for Base Discharge Current.

The Dynamic Capacity Test is intended to measure the capacity of a module under dynamic discharge conditions. The dynamic cycle is scaled to a fraction of 
the rated power for the module to be tested. The USABC Dynamic Stress Test (DST) is used for some chemistries but in fact is a different test.

\section{Analysis:}

These procedures are done well with good reasoning and helps establish common procedures for the industry to use. However, the document falls short since it does not address the temperature testing needs. Batteries can be very sensitive to temperature variations. Some batteries are more tolerant of temperature sensitivities than others. Procedures need to be developed for temperature sensitivities so that application owners can compare technologies or chemistries to make better decisions.

\section{Document Location:}

http://www.sae.org/servlets/works/documentHome.do?comtID=TEVHYB\&doclD= $\underline{J 1798200807 \text { \&inputPage }=\text { dOcDeTallS }}$ 


\section{SAE J-1850: Class B Data Communications Network Interface}

\section{Status:}

Reaffirmed: June 2006 and 46 pages in length

Reaffirmed: May 2001

Issued: November 1988 (Original)

\section{Overview:}

This SAE Standard establishes the requirements for Class B Data

Communications Network Interface applicable to all on-road and off-road landbased vehicles. It defines a minimum set of data communications requirements such that the resulting network is cost effective for simple applications and flexible enough to use in complex applications.

\section{Analysis:}

This document has had several updates. The document has complied with the SAE 5-Year Review policy. The document is deemed to be obsolete now that the J-1772 Recommended Practice no longer has J1850 terminals within the connector.

Document Location:

http://www.sae.org/technical/standards/J1850 200606 


\section{SAE J-2288: Life Cycle Testing of Electric Vehicle Battery Modules}

\section{Status:}

Reaffirmed: June 2008 and 5 pages in length

Issued: January 1997 (Original)

\section{Overview:}

This Recommended Practice was established to define a standardized method to determine the expected service life cycles of electric vehicle battery modules. The method does not include any accelerated life testing. The standard sets up the test conditions for test including temperature, temperature sensing, data recording and frequency. The procedure is identified with initial reference tests, the Dynamic Capacity Test from SAE J-1798 and its constraints. Finally, it describes the end of life conditions which may include the measured capacity to be less than $80 \%$ of the rated capacity, the peak-power capability is than $80 \%$ of its rated value at $20 \%$ State of Charge.

\section{Analysis:}

This standard has recently been reaffirmed. It does establish a standard for manufacturers of modules to test for comparison to other modules to be similar or not. The procedure does not include temperature variation in the modules. The temperature variation in the modules typically is life reducing. Temperature testing is a very important characteristic that should be addressed.

This approach is considered appropriate for a mature design or production battery. This procedure is functional identical to the USABC Baseline Life Cycle Test Procedure.

\section{Document Location:}

http://www.sae.org/servlets/works/documentHome.do?comtID=TEVHYB\&doclD= $\underline{\text { J2288 200806\&inputPage }=\text { dOcDeTallS }}$ 


\section{SAE J-2289: Electric-Drive Battery Pack System: Functional Guidelines}

\section{Status:}

Revised: July 2008 and 14 pages in length

Issued: November 2000 (Original)

\section{Overview:}

This document provides guidance in designing battery systems for Electric and Hybrid Vehicles. It describes common practices for the Energy Storage Systems (ESS). The paper is divided into four major groups as physical requirements, electrical requirements, environmental requirements, and marking and labels.

Physical Requirements include mechanical retention, installation/removal for service, clearance, and durability requirements.

Electrical Requirements include operational modes, electrical ratings, EMI/RFC Emissions and Susceptibility, high power connection requirements, electrical isolation, monitoring/control interfaces, diagnostics and service.

Environmental Requirements include environmental range, hazardous physical emissions, and gaseous emissions management.

Markings and Labeling includes recycling, storage, and shipment.

\section{Analysis:}

This publication provides practical requirements for making battery packs safe as well as robust to the environment. It should be used for reference of Battery Pack or ESS requirements.

Document Location:

http://www.sae.org/servlets/works/documentHome.do?comtlD=TEVHYB\&doclD= $\underline{\text { J2289 200807\&inputPage }=\text { dOcDeTallS }}$ 


\section{SAE J-2293 Part 1: Energy Transfer System for EV Part 1: Functional Requirements and System Architecture}

\section{Status:}

Reaffirmed: July 2008 and 84 pages in length

Issued: March 1997 (Original)

\section{Overview:}

This Recommended Practice has been updated and refers to both the Conductive charging Standard (J-1772) and the Inductive Charging Standard (J1773). This is also the first part of two parts. The other part is Energy Transfer System for EV Part 2: Communications Requirements and Network Architecture (J-2293 Part 2).

When an EV and an EVSE are coupled, energy and information is exchanged. J2293-1 describes the overall information and energy exchange that occurs. J2293-2 describes the requirements for exchanging data between an EV and EVSE via J-1850.

This document consists of two parts, as shown in the figure below from the document. J-2293-1 is published separately from J-2293-2. They are divided up as shown in this figure. J-2293-1 describes the total EV-ETS and allocates requirements to the EV and EVSE for the different system architectures. J-22932 describes the communications network between the EV and the EVSE for the ETS Network. It treats the network as a system from part 1 as external elements using the network.

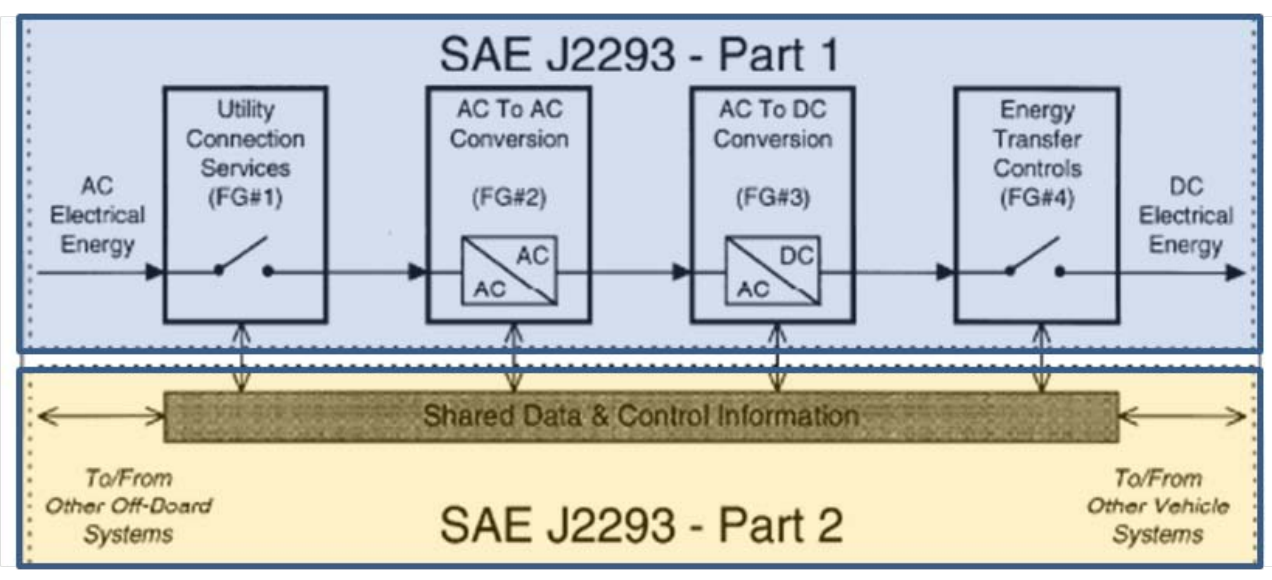

The figure below describes the document interrelationship as shown in the document. J1850, J1772, and J1773 as well as J2293 are all important documents to ensure that it is possible to have an EV and EVSE system support more than one architecture. 


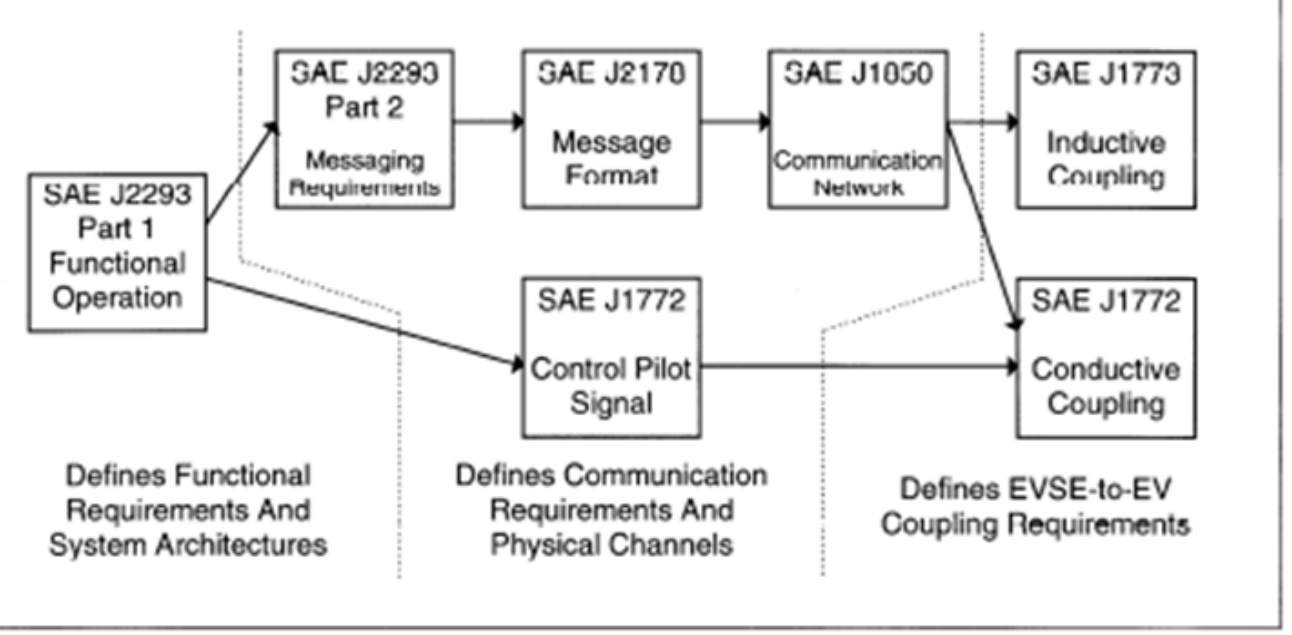

J-2293-1 defines three different Energy Transfer Systems (ETS). J-2293-1 defines the information that passed between EV and EVSE. The architectures require different information. Three variations of system architectures shall be referenced by the following:

Type A - Conductive AC System Architecture

Type B - Inductive System Architecture

Type C - Conductive DC System Architecture

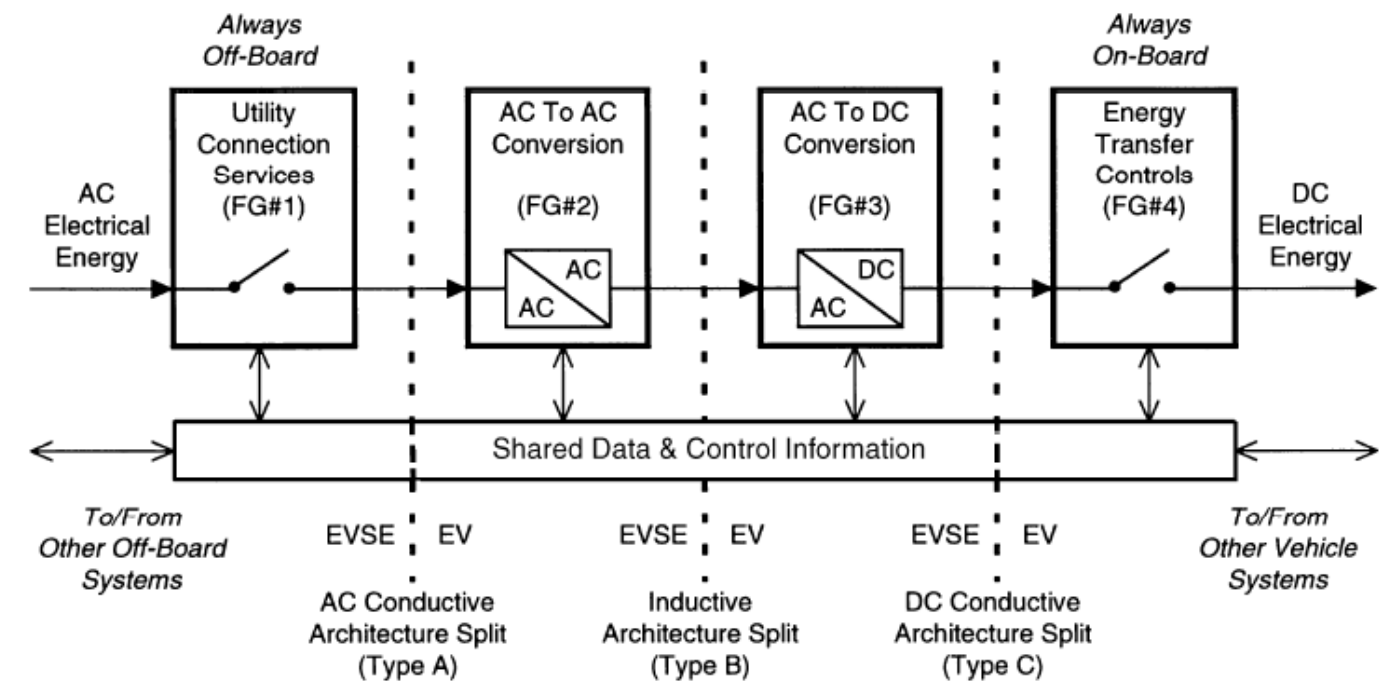

The EV Energy Transfer system (ETS) converts AC electrical energy from the utility grid in DC electrical energy for storage in the EV storage battery. The system includes functionality that will be implemented both on-board the EV as well off-boards as a part of the EVSE. The system will not have physical partitioning of the components. It will be described as groups of functions that are implemented as either a part of the EV or the EVSE. The functional groups are shown int the above diagram. Three different architectures will be used as described above. 
The document defines the following:

- All the external interfaces are defined.

- Functional Content and Constraints are provided.

- Physical Content and Constraints are provided.

- Functional System Requirements are described.

- Switch and Convert Electrical Energy

- Determine Ready to Transfer Electrical Energy

- Control Transfer of Electrical Energy

- System Architecture

- Requirements Allocation for Functional Groups 1, 2, 3, and 4

- Architecture Variations- Type A, Type B and Type C

\section{Analysis:}

The procedures in this standard have been updated to keep this Practice updated. A new practice ( $\mathrm{J}-2847$ Part 1 ) is being assembled to replace this $\mathrm{J}$ 2293 in the longer term.

The Task Force is now updating this Practice with another Recommended Practice (J-2847 Parts 1, 2, and 3). This new practice includes the following: the desire for bi-directional communications to the grid, updating the medium communications to Power Line Communications (PLC) or wireless, and conforming to the new, updated Conductive Charging Practice (J-1772). Also new EV architectures are being considered such as Plug-In Hybrids.

\section{Document Location:}

http://www.sae.org/servlets/works/documentHome.do?comtID=TEVHYB\&doclD= J2293/1 200807\&inputPage=dOcDeTallS 


\title{
SAE J-2293 Part 2: Energy Transfer System for EV Part 2: Communications Requirements and Network Architecture
}

\author{
Status: \\ Reaffirmed: July 2008 and 196 pages in length \\ Issued: May 1997 (Original)
}

\section{Overview:}

Refer to the overview of the J-2293-1 for the general overview. $\mathrm{J}-2293-2$ defines the requirements for a common set of methods to exchange information between EV and EVSE independent of the architecture. It defines the relationship between the data flows defined J-2293-1 and the messages that communicate those data flows.

To allow maximum flexibility in the use of this network and it communications, this document supports "Open Architecture." This used to describe a set of goals to enable future expansion of the network.

Four key areas are addressed System Definition and Context, Functional Requirements, System Architecture, and Validation. Each of these sections is detailed for the system.

\section{Analysis:}

The procedures in this standard have been updated to keep this Practice updated. A new practice ( $\mathrm{J}-2847$ Part 2 ) is being assembled to replace this $\mathrm{J}$ 2293 in the longer term.

The Task Force is now updating this Practice with another Recommended Practice (J-2847 Parts 1, 2, and 3). This new practice includes the following: the desire for bi-directional communications to the grid, updating the medium communications to Power Line Communications (PLC) or wireless, and conforming to the new, updated Conductive Charging Practice (J-1772). Also new EV architectures are being considered such as Plug-In Hybrids.

\section{Document Location:}

http://www.sae.org/servlets/works/documentHome.do?comtID=TEVHYB\&doclD= $\underline{\text { J2293/2 200807\&inputPage }=\text { dOcDeTallS }}$ 


\section{SAE J-2344: Guidelines for Electric Vehicle Safety}

\section{Status:}

WIP official ballot in August 2009

Issued: June 1998 (Original) and 11 pages in length

\section{Overview:}

This SAE information report identifies and defines the preferred technical guidelines relating to safety for Electric vehicles during normal operation and charging. It will provide introductory safety guidelines that should be considered when designing electric vehicles for use on public roads.

The Technical Safety Guidelines addressed in this document are the following: EV Crashworthiness (refer to J1766), Single-Point Failure, Electrical Safety, Fault Monitoring, Hazardous Gas Leakage, Vehicle Immersion, Electromagnetic Compatibility, Safety Labeling, Mechanical Safety, and Battery State-of-Charge.

Each of these topics contains many subtopics in their categories. The Electrical Safety section contains paragraphs on Automatic Hazardous Voltage Disconnect, Manual Disconnects, and Interlocks.

\section{Actual Changes to the new document are to:}

1. Explicitly include HEV \& other Plug-In Vehicles

2. Update terms (Traction Battery to RESS, etc)

3. Move the isolation requirements from the definition section (3.8) to the requirement section (4.3.1)

4. Update isolation requirement to include $100 \mathrm{ohms} / \mathrm{volt}$ to match $\mathrm{J} 1766$ and $\mathrm{J} 2578$

5. Delete the monitoring criteria for $\mathrm{HV}$ isolation.

6. Delete the 500 ohms/volt for the DC bus during charging.

In the new document, the $A C$ body current has not changed from the previous version ( $2 \mathrm{~mA}$ or 500 ohms/volt). However, the DC body current has changed from $2 \mathrm{~mA}$ to $10 \mathrm{~mA}$ ( $500 \mathrm{ohms} / \mathrm{volt}$ to $100 \mathrm{ohms} / \mathrm{volt}$ ). Please reference the figures below from Rich Scholer. 


\section{AC Requirement}

\section{IEC 479 Figure 14 Time / Current Zones, Effects of AC Current}

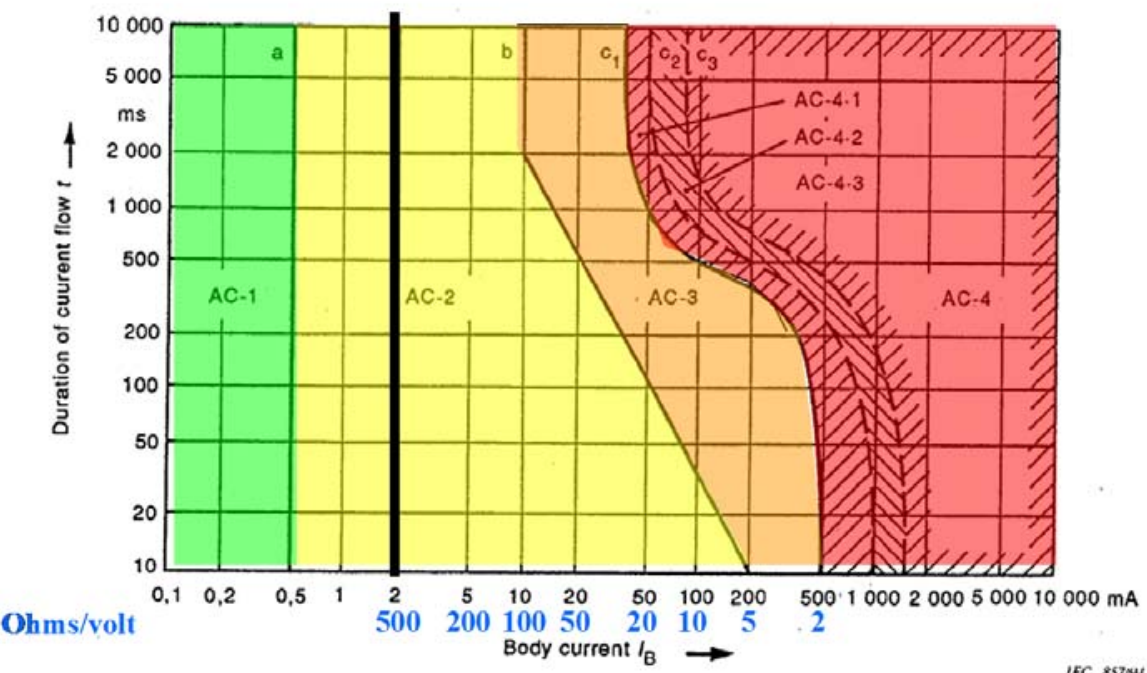

7-15-08

Rich Scholer - Requirement,

\section{Requirement}

\section{IEC 479-1 Figure 15 - Time / Current Zones,} Effects of DC Currents

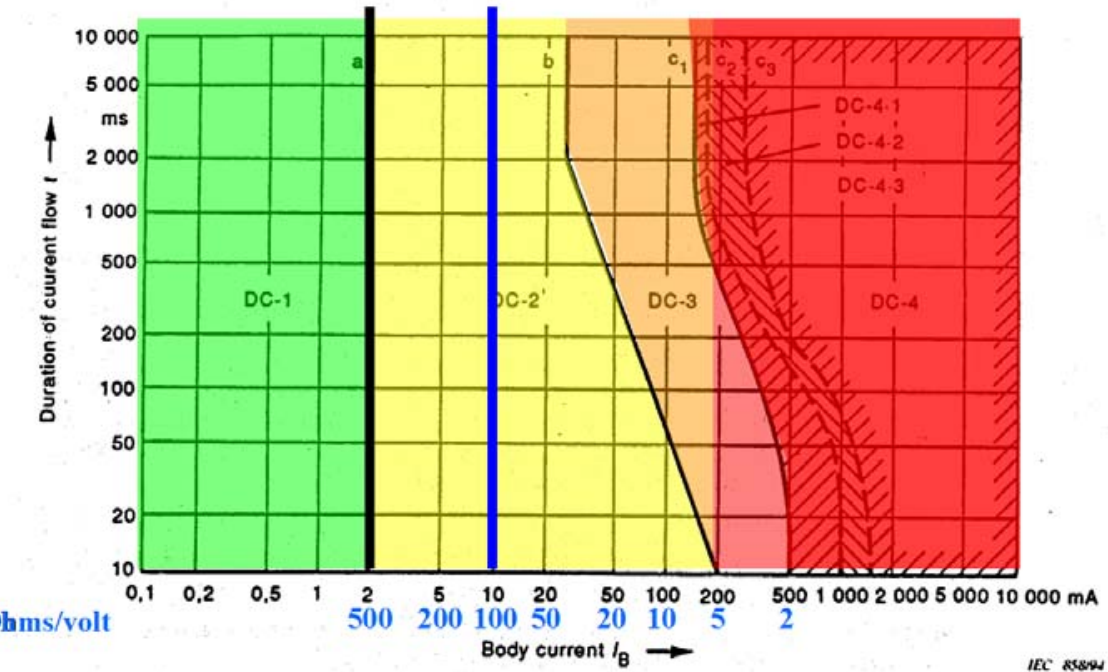




\section{Analysis:}

The 1998 version of this document is presently being updated. The last comments are in for before balloting. The document balloting is occurring in August 2009 and should be published by the end of 2009. This document does a very good job of defining as well as setting guidelines for electric vehicle safety.

Document Location: 1998 Document

http://www.sae.org/servlets/works/documentHome.do?comtID=TEVHYB\&doclD= $\underline{\text { J2344 199806\&inputPage }=\text { dOcDeTallS }}$ 


\section{SAE J-2380: Vibration Testing of Electric Vehicle Batteries}

\section{Status:}

Revised: March 2009 and 7 pages in length

Issued: January 1998 (Original)

\section{Overview:}

This Recommended Practice provides a test procedure for characterizing the effect of long-term, road-induced vibration and shock on the performance and service life of the electric vehicles batteries. The intent of the procedure is to qualify the vibration durability of a mature, production-ready battery. This test is designed for the vibration durability of a single battery (test unit) consisting of either an electric vehicle battery module or an electric vehicle battery pack.

This procedure provides the equipment needed to do the procedure including instrumentation. It also assists in the determination of Test Conditions and Criteria. Finally the test procedure is laid out with two or three axis vibration data. Tables are provided to program the shaker table.

\section{Analysis:}

This analysis and its procedure is a good starting point for battery modules and battery packs. However, each application of a battery is different than the one shown here. It is hard to believe that a battery module and a battery pack would see the same vibration. Yet, this specification indicates that the same vibration should be administered to module or the pack.

Also it is critical to know how the battery pack is mounted to the vehicle. It is possible to either hard-mount the pack to the vehicle or soft-mount it. Both these ways would provide different results.

In a similar way, how the battery module is mounted in the battery pack would allow a different vibration regime.

Vibration data for batteries and battery packs is different for every application. Understand this Recommended Practice, but do not take it specifically for any application.

\section{Document Location:}

http://www.sae.org/servlets/works/documentHome.do?comtID=TEVHYB\&docID= $\underline{\text { J2380 200903\&inputPage }=\text { dOcDeTallS }}$ 


\section{SAE J-2464: Electric and Hybrid Electric Vehicle Rechargeable Energy Storage System (RESS) Safety and Abuse Testing}

\section{Status:}

WIP in progress August 2009

Issued: March 1999 (Original) and 15 pages in length

\section{Overview:}

The original title of this document was Electric Vehicle Battery Abuse Testing. It limited the scope to batteries only. The new version intends to improve and expand the scope of the original. The scope is expanded to other electric storage devices other than batteries. These devices include electrochemical capacitors, etc. It also includes new types of electrified vehicular designs.

The other goals of the new version make the test results more quantitative, incorporate improvements in test procedures and data analysis, harmonize wording with other test standards used today, and importantly, provide expert guidance to the automotive community on how and what abuse tests to perform on batteries for HEVs and EVs.

This Recommended Practice is intended as a guide toward standard practice and is subject to change to keep pace with experience and technical advances. This document is derived from a similar document developed by the United States Advanced Battery Consortium (USABC).

These tests are intended to stimulate abuse conditions and potential internally initiated failures that may be experienced in electrochemical storage systems. The tests are derived from Failure Mode and Effect Analysis, user input, and historical abuse testing. Users of these technologies shall make their own determination as to what measures to take to ensure a sound application of the technology.

The tests are independent of the type of chemistries that are used.

The technical requirements are described. The General Test Guidelinessubjecting batteries to conditions outside their intended use can involve some risk of unintended failures. Included in the general test guidelines are Hazardous Substance Monitoring, Test conditions and measurement accuracies, and number, condition, and size of batteries to be tested.

The Mechanical Abuse Tests are provided and include shock tests at the module or above level, drop tests for packs, penetration tests for cell level or above, roll-over tests for module level or above, immersion tests for module level or above, and crush tests for cell level or above. 
The Thermal Abuse Tests are also considered. They include the radiant heat tests for the cell level or above, thermal stability test for the cell level or above, the compromise of thermal insulation for the module level or above, overheat/ thermal run away tests for module level or above, thermal shock cycling tests for the cell level or above, and the elevated temperature storage tests for the cell level or above.

The Electrical Abuse Tests are defined. The abuse tests include short circuit tests, partial short circuit tests, overcharge tests, over discharge tests, and extreme cold tests.

\section{The following are added to the new document.}

Hazard Severity Level Scores will be assigned. Abuse testing is performed to characterize response of RESS to "off-normal" conditions. "Off-Normal Conditions" are designed to simulate actual use and abuse conditions, such as:

1. operator negligence,

2. vehicle accidents,

3. device or system defects,

4. poorly informed or trained users or mechanics,

5. failure of specific RESS control and support hardware, or

6. transportation / handling incidents or accidents.

Likelihood Level Scale has been developed. It is rating of 1 to 10 where 10 is an extremely high hazard rate and 1 is a Very Low Hazard rate. The following space is defined in the practice.

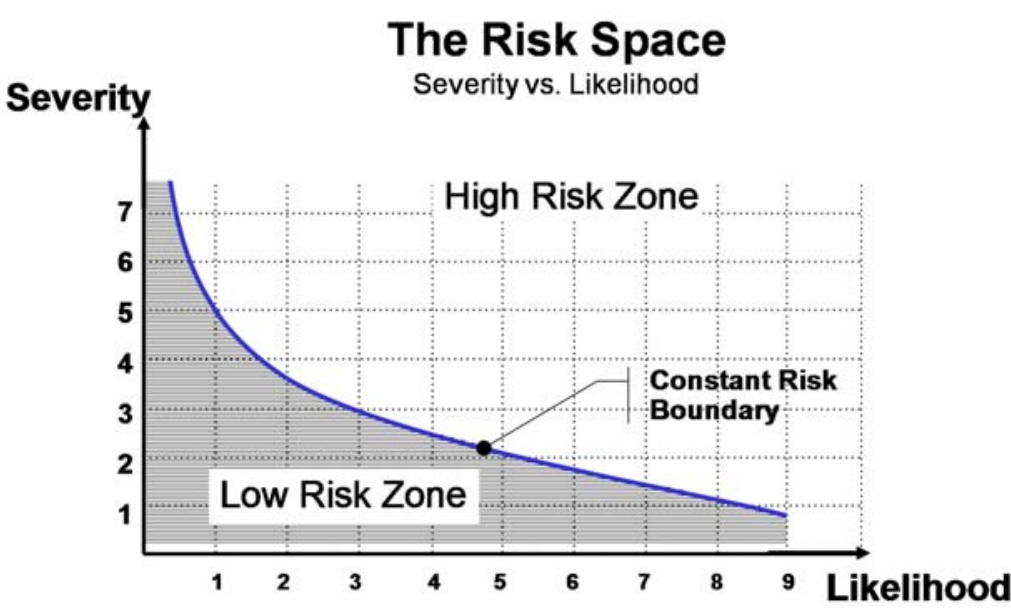


Hazardous Substance Monitoring is a new test for this new document. A complete set of analyses will be done at the cell level, with a recommended analysis of gases and vapors produced at the pack level as an adjunct to other tests. This eliminates the need for repeated Hazardous Substance Monitoring, which was required for many tests in the old version. Four types of tests are to be conducted:

1) Electrolyte vapor analysis.

2) RESS cell forced vent without thermal runaway.

3) RESS cell forced vent with thermal runaway.

4) Pack level hazardous substance monitoring will be performed in conjunction with one other pack level abuse tests during which combustion of the RESS cells and RESS pack materials is expected.

Pressure-Induced Internal Short-Circuit is another new test. The purpose of this test is to measure the cell response to pressure-induced internal shorting between the cell electrodes. Internal shorting between electrodes is attempted to be induced by slowly increasing the pressure of a blunt-tipped cylindrical rod through deformation of the cell case without penetration. The deformation may continue until full penetration of the cell.

- This test aims to determine the severity of the cell response to internal short circuit for different cell chemistries, components (such as separators) and cell designs.

- This test should be performed at a constant, slow rate (not to exceed 1 $\mathrm{mm} / \mathbf{s e c}$ ) so that the cell skin temperature can respond to any internally induced shorts. A steel rod of $3 \mathrm{~mm}$ diameter with a round tip of radius 1.5 $\mathrm{mm}$ will be used.

Passive Propagation Resistance Test is another new test. This test evaluates the ability of a RESS to withstand a single cell thermal runaway event.

- The RESS is heated until the cells stabilize at $55^{\circ} \mathrm{C}$ or the maximum operating temperature, whichever is greater.

- One cell within the RESS (repeated at the 5 locations described below) is uniformly heated in-situ in less than 5 minutes to a temperature of $400^{\circ} \mathrm{C}$ (or until the cell enters thermal runaway).

- The geometric corner of the RESS Module or Pack.

- At the midpoint of an edge.

- At the center of one face. 
- The interior of the RESS Module or Pack 1/4 the distance from the center of a face (B) to the opposite face.

- The interior of the RESS Module or Pack 1/4 the distance from the center of a face $(C)$ to the opposite face.

Separator Shutdown Integrity Test is another new test. This test applies only to cells that have a shutdown separator.

- Heat the cell to at least $5^{\circ} \mathrm{C}$ above the measured shutdown temperature.

- Once this temperature has stabilized for 10 minutes, apply the high-level over voltage (at least $20 \mathrm{~V}$ ) with a current limit of less than $1 \mathrm{C}$.

- Maintain the applied voltage for a minimum of 30 minutes or until the separator fails.

\section{Analysis:}

A great effort goes forward to ensure the test processes are sequenced correctly. The new version of the document is much simplified from the original. Affirmation occurred and passed in August 2009. Document is being reformatted for publication. The Motor Vehicle Council (MVC) approval is required. The document should be published by the end of 2009 .

The new document has been in committee since February 2007. In January 2009, a revised draft was presented to the Hybrid Technical Committee. The committee has done an extensive job on improving the document. All the tests have been extensively reviewed by experts in the field.

The Hazardous Substance Monitoring test is a good test, but it is believed not to be required in a standard like this. The battery manufacturer should take the responsibility of doing the due diligence on the product.

\section{Document Location:}

http://www.sae.org/servlets/works/documentHome.do?comtID=TEVHYB\&docID= $\underline{\text { J2464 199903\&inputPage }=\text { dOcDeTallS }}$ 


\section{SAE J-2711: Recommended Practice for Measuring Fuel Economy and Emissions of Hybrid-Electric and Conventional Heavy Duty Vehicles}

\section{Status:}

Issued: September 2002 and 68 pages in length

\section{Overview:}

This Recommended Practice was established to provide an accurate, uniform, and reproducible procedure for simulating use of heavy-duty hybrid-electric vehicles and conventional vehicles on chassis dynamometers for the purpose of measuring emissions and fuel economy. This Practice can use any schedule, but it does recommend three different schedules- the Manhattan schedule (representing a low speed transit bus operation), the Orange county schedule (representing intermediate speed bus operation), and the Urban Dynamometer Driving Schedule (UDDS) (representing high speed operations for buses and tractor trailers). This document builds upon SAE J1711, the light-duty HEV Chassis recommended practice.

Calculation for Net Energy Change (NEC) is shown for batteries, capacitors, and flywheels. NEC Variance is determined. State of Charge (SOC) correction procedure is developed.

\section{Analysis:}

This publication was published in 2002 and needs to be updated. The SAE Hybrid Committee is not responsible for this document rather the Truck and Bus Committee is responsible.

Document Location:

http://www.sae.org/technical/standards/J2711 200209 


\section{SAE J-2758: Determination of the Maximum Available Power from a Rechargeable Energy Storage System on a Hybrid Electric Vehicle}

\section{Status:}

Issued: April 2007 and 7 pages in length

\section{Overview:}

This document provides a method to determine the maximum power for a battery similar to defining maximum power for an engine. The Test Description includes the following: the tests to be performed, Battery Preparation, Static Capacity Test Procedure, Peak Power Test procedure, and the Calculations for Predicted Peak Power and Maximum Sustainable Current.

\section{Analysis:}

This publication provides a standard so that comparisons amongst battery systems can be completed in harmony.

\section{Document Location:}

http://www.sae.org/servlets/works/documentHome.do?comtID=TEVHYB\&doclD= $\underline{\mathrm{J} 2758 \text { 200704\&inputPage }=\text { dOcDeTallS }}$ 


\section{SAE J-2836 Part 1: Use Cases for Communications between Plug-In Vehicles and the Utility Grid}

\section{Status:}

WIP in Progress April 2009

Issued: No Originals

\section{Overview:}

This Information Report establishes use cases for communications between pluin vehicles and the electric power grid for energy transfer and other applications. This report does not cover energy outgoing from the vehicle, but rather only incoming to the vehicle (Forward Power and not Reverse Power).

Each use case is described with the following components:

- Brief Written Description

- Scenario Mix

- Equipment Diagram

- Communication Path Diagram

- Activity Diagram

- Sequence Diagram

Equipment and Devices are described.

Three kinds of messages are described: Basic (required), Enhanced, and Optional.

Three applications are derived with the information shown above as follows:

- Cordset at Home

- EVSE Cord at Home

- EVSE with off-board charger at Home

\section{Analysis:}

The committee is working the latest copy of the document is a Work-in-Progress. The structure of the document looks complete, but the definitions are now being defined. Document should replace the J-2293 Recommended Practice when it is complete.

Document Location:

Not Applicable at this time 


\section{SAE J-2836 Part 2: Use Cases for Communications between Plug-In Vehicles and the Supply Equipment (EVSE)}

\section{Status:}

WIP in Progress February 2009

Issued: No Originals

\section{Overview:}

This Information Report establishes use cases for communications between plug-in vehicles and the Supply Equipment (EVSE) for energy transfer and other applications. This report does not cover energy outgoing from the vehicle, but rather only incoming to the vehicle (Forward Power and not Reverse Power). Each use case is described with the following components:

1. Brief Written Description

2. Scenario Mix

3. Equipment Diagram

4. Communication Path Diagram

5. Activity Diagram

6. Sequence Diagram

7. Equipment and Devices are described

\section{Analysis:}

The committee is working the latest copy of the document is a Work-in-Progress. The structure of the document looks complete, but the definitions are now being defined. Requirements are all missing at this time. Document should replace the J-2293 Recommended Practice when it is complete.

Document Location:

Not Applicable at this time 


\section{SAE J-2836 part 3: Use Cases for Communications between Plug-In Vehicles and the Utility grid for Reverse Flow}

\section{Status:}

WIP in Progress February 2009

Issued: No Originals

\section{Overview:}

This Information Report establishes use cases for communications between plug-in vehicles and the Utility Grid for Reverse Flow for energy transfer and other applications. This report does not cover energy outgoing from the vehicle, but rather only incoming to the vehicle (Forward Power and not Reverse Power). Each use case is described with the following components:

1. Brief Written Description

2. Scenario Mix

3. Equipment Diagram

4. Communication Path Diagram

5. Activity Diagram

6. Sequence Diagram

\section{Analysis:}

The committee is working the latest copy of the document is a Work-in-Progress. The structure of the document looks complete, but the definitions are now being defined. Requirements are all missing at this time. Document should replace the J-2293 Recommended Practice when it is complete.

Document Location:

Not Applicable at this time 


\section{SAE J-2841: Utility Factor Definitions for Plug-In Hybrid Electric Vehicles Using 2001 U.S. DOT National Household Travel Survey Data}

\section{Status:}

WIP in Progress

Issued: March 2009 and 15 pages in length

\section{Overview:}

This is a recent republication that defines the Utility Factor to be used for Fuel Consumption calculations for Plug-In Hybrid Electric Vehicles. The standard uses the 2001 United States DOT "National Household Travel Survey" as the basis for the analysis. Tables of the Utility Factors for the UDDS and the HWY are shown versus Charge Depletion Range. A set of coefficients are provided for an exponential equation. The data is the plot provided here from the document.

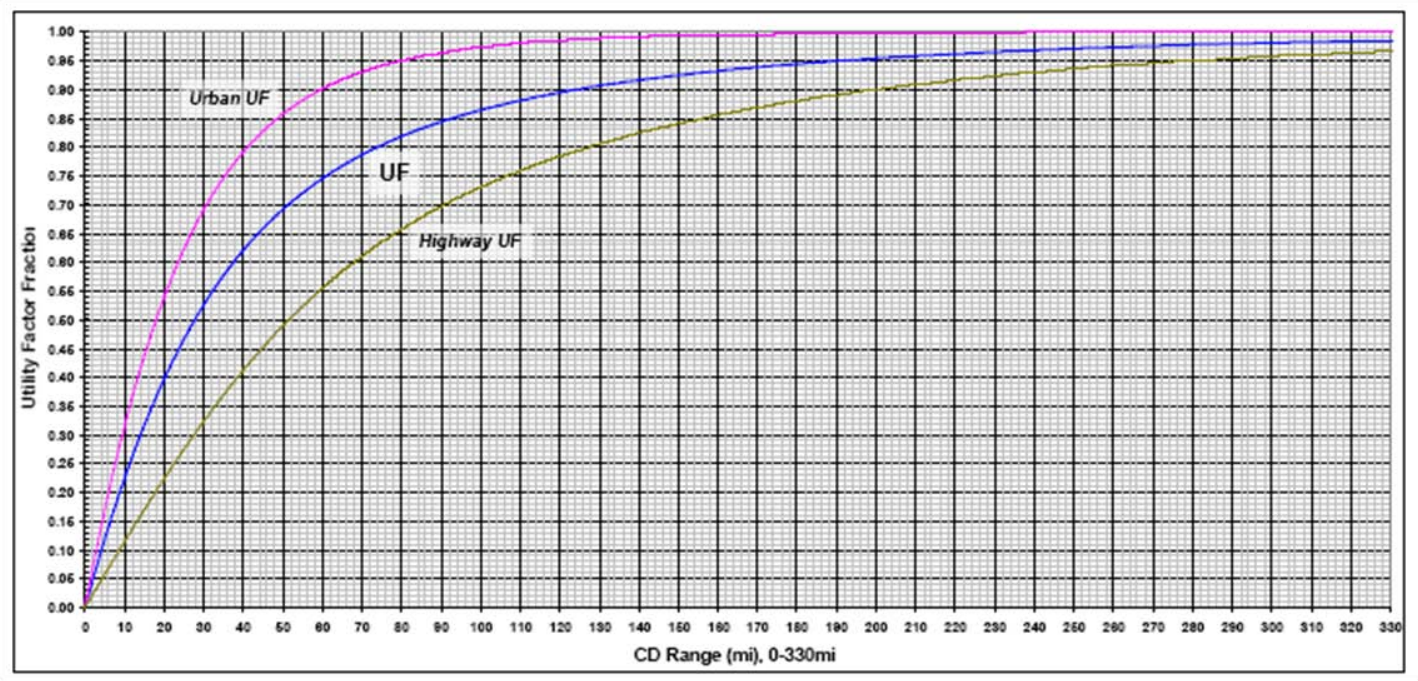

\section{Analysis:}

This new publication provides three Utility Factors (UF) instead of only one from the original publication. A UF is defined for the UDDS, the HWY, and the mean. The UF for the UDDS is now higher then prior and the HWY UF is lower than prior. This is definitely an improvement over the previous version in that the three UFs are independent and not lumped together. See the change shown below.

\begin{tabular}{|c|c|c|c|}
\hline & UDDS & Mean & HWFET \\
\hline $\begin{array}{l}\text { Amount Higher than original UF } \\
\text { at } 60 \text { miles of range point }\end{array}$ & $43 \%$ & $19 \%$ & $-13 \%$ \\
\hline
\end{tabular}


This document was recently published but new Utility Factors are again emerging. Emeskay and Georgia Tech are using some Atlanta Real-Use data and establishing new individual UFs and not fleet UFs. This document again will be balloted and published by the end of 2009 with a new UF.

\section{Document Location:}

http://www.sae.org/servlets/works/documentHome.do?comtID=TEVHYB\&docID= $\underline{\text { J2841 200903\&inputPage }=\text { dOcDeTallS }}$ 


\section{SAE J-2847 Part 1: Communications between Plug-In Vehicles and the Utility Grid}

\section{Status:}

WIP in Progress April 2009

Issued: No Originals

\section{Overview:}

This Recommended Practice establishes requirements and specifications for communications between plug-in electric vehicles and the utility grid for energy transfer and other applications. The purpose of the document is grid-optimized energy transfer for plug-in electric vehicles. It ensures that vehicle operators have sufficient energy for driving while enabling the delivery of that energy to the vehicles in ways that minimize stress upon the grid.

This document supports AC or DC energy transfer. Part 2 supports the additional messages for DC energy transfer and replaces Energy Transfer System for EV Part 1: Functional Requirements and System Architecture (J-2293)

This document is being written to synchronize with the revised edition of $S A E$ Electric Vehicle Conductive Charge Coupler (J-1772).

This document does not support SAE Electric Vehicle Inductively-Coupled Charging (J-1773) or Energy Transfer System for EV Part 1: Functional Requirements and System Architecture (J-2293) since they are obsolete.

\section{Technical Requirements:}

The messages within this document apply when the customer enrollments in one or more of the following utility programs:

U1: Time-Of-Use rates/Tariffs /Programs (Loading Shifting)

U2: Direct Load Control Programs (Demand Response)

U3: Real Time Pricing (RTP: Load Shifting /Demand Response) (Active management)

U4: Critical Peak Pricing (CPP / Load Shifting /Demand Response)

U5: Optimized Energy Transfer Programs (Demand Response, Regulation Services, etc)

Equipment and Devices are documented and considers automotive modules Communications messages are defined in detail.

\section{Analysis:}

The latest copy of the Work-in-Progress is April 2009. The structure of the standard is available but the definitions need to be worked. It is too early to make a judgment on missing information. The targeted ballot time is November 2009.

Document Location: Not Applicable at this time 


\section{SAE J-2847 Part 2: Communication between Plug-in Vehicles and the Supply Equipment (EVSE)}

Status:

WIP in Progress

Issued: No Originals

\section{Overview:}

This Recommended Practice establishes the communications structures between plug-in electric vehicles and the Supply Equipment for energy transfer and other applications. The purpose of the document is to support the use cases identified in J-2836-2 for DC energy flow to the plug-in vehicle. SAE J-2293 is used as the basis for this document.

\section{Analysis:}

The latest copy of the Work-in-Progress is April 2009. The structure of the standard is available. Presently there are no technical requirements defined in the document. It is too early to make a judgment on missing information. The committee is working hard to make sure the technical requirements will be suitable.

Document Location:

Not Applicable at this time 


\section{SAE J-2847 Part 3: Communication between Plug-in Vehicles and the Utility Grid for Reverse Power Flow}

\section{Status:}

WIP in Progress

Issued: No Originals

\section{Overview:}

This Recommended Practice establishes the communications structures between plug-in electric vehicles and the Supply Equipment for energy transfer and other applications for reverse flow. The purpose of the document is to support the use cases identified in J-2836-2 for DC energy flow to the plug-in vehicle. SAE J-2293 is used as the basis for this document.

\section{Analysis:}

The latest copy of the Work-in-Progress is February 2009. The structure of the standard is available. Presently there are no technical requirements defined in the document. It is too early to make a judgment on missing information. The committee is working hard to make sure the technical requirements will be suitable.

Document Location:

Not Applicable at this time 


\section{SAE J-2889: Measurement of Minimum Sound Levels of Passenger Vehicles}

Status:

WIP in Progress

Issued: No Originals

Overview:

There is a draft standard in process for a method to measure the minimum sound level of passenger vehicles. (At present there are procedures only for the maximum pass-by noise of vehicles.)

The actual minimum level required would presumably be set by regulators following the completion of studies by NHTSA, a period for notice of rulemaking, and imposition of rules.

\section{Analysis:}

The new draft standard is owned by the Human Factors Committee, and will be cleared through the External Noise committee.

This method would be used to determine the sound levels required for the blind to hear an electric vehicle.

Document Location:

Not Applicable at this time 


\section{SAE J-2894 Part 1: Power Quality Requirements for Plug-In Vehicle Chargers - Requirements}

\section{Status:}

WIP in Progress

Issued: No Originals

\section{Overview:}

This Recommended Practice is based off of an IWC/EPRI document for Power Quality. It enables vehicle manufacturers, charging equipment manufacturers and utilities to make reasonable design decisions regarding power quality. Requirements will be described for the power quality of the charger. The standard will be in two parts- Part 1 is the requirements and Part 2 is the Test Procedure.

This Recommended Practice will include guidelines for:

Total Power Factor

Power Conversion Efficiency

Total Harmonic Current Distortion

Current Distortion at Each Harmonic Frequency

Plug in Electric Vehicle Charger Restart After Loss of AC Power Supply

Charger / Electric Vehicle Supply Equipment AC Input Voltage Range

Charger / Electric Vehicle Supply Equipment AC Input Voltage Swell

Charger / Electric Vehicle Supply Equipment AC Input Voltage Surge (Impulse)

Charger / Electric Vehicle Supply Equipment AC Input Voltage Sag

Charger / Electric Vehicle Supply Equipment AC Input Frequency Variations

In-Rush Current

Momentary Outage Ride-Through

\section{Analysis:}

A roster will be created and the standard work will begin. It is under the auspices of the Hybrid Committee. The committee expects to be balloted by the end of 2009. This is good to have a common set of requirements for chargers since many different vehicles could be using the hardware. It is important the chargers and connections be compatible from all aspects.

Document Location:

http://www.sae.org/servlets/works/documentHome.do?doclD=J2894\&inputPage= wlpSdOcDeTallS\&comtID=TEVHYB 


\section{SAE J-2894 Part 2: Power Quality Requirements for Plug-In Vehicle Chargers - Test Methods}

\section{Status:}

WIP in Progress

Issued: No Originals

\section{Overview:}

This Recommended Practice is based off of an IWC/EPRI document for power Quality. It enables vehicle manufacturers, charging equipment manufacturers and utilities to make reasonable design decisions regarding power quality.

Test methods will be described for the power quality of the charger. It will include guidelines for total power factor, power conversion efficiency, total harmonic current distortion, and current distortion at each harmonic frequency. The standard will be in two parts - Part 1 is the requirements and Part 2 is the Test Procedure.

This Recommended Practice will include guidelines for:

Total Power Factor

Power Conversion Efficiency

Total Harmonic Current Distortion

Current Distortion at Each Harmonic Frequency

Plug in Electric Vehicle Charger Restart After Loss of AC Power Supply

Charger / Electric Vehicle Supply Equipment AC Input Voltage Range

Charger / Electric Vehicle Supply Equipment AC Input Voltage Swell

Charger / Electric Vehicle Supply Equipment AC Input Voltage Surge (Impulse)

Charger / Electric Vehicle Supply Equipment AC Input Voltage Sag

Charger / Electric Vehicle Supply Equipment AC Input Frequency Variations

In-Rush Current

Momentary Outage Ride-Through

\section{Analysis:}

A roster will be created and the standard begins. It is under the auspices of the Hybrid Committee. This document will be published much later than the $1^{\text {st }}$ part. The requirements need to be assigned before testing can be examined.

\section{Document Location:}

http://www.sae.org/servlets/works/documentHome.do?doclD=J2894/2\&inputPag e=wlpSdOcDeTallS\&comtID=TEVHYB 


\section{SAE J-2907: Power Rating Method for Automotive Electric Propulsion Motor and Power Electronics Sub-System}

\section{Status:}

WIP in Progress

Issued: No Originals

\section{Overview:}

This Recommended Practice will describe power rating for automotive propulsion systems including the motors and inverters.

\section{Analysis:}

A roster will be created and the standard begins. It is under the auspices of the Hybrid Committee. A common power rating for comparison within the industry is important and this document will attempt to do that.

Document Location:

Not Applicable at this time 


\section{SAE J-2908: Power Rating Method for Hybrid-Electric and Battery Electric Vehicle Propulsion}

\section{Status:}

WIP in Progress

Issued: No Originals

\section{Overview:}

This Recommended Practice will describe power rating for automotive hybridelectric and electric vehicle propulsion

\section{Analysis:}

A roster will be created and the standard begins. It is under the auspices of the Hybrid Committee. A common power rating for comparison within the industry is important and this document will attempt to do that.

Document Location:

Not Applicable at this time 


\section{ISO/FDIS 6469-1:2009(E): "Electrically propelled road vehicles - Safety specification - Part 1: On-board rechargeable energy storage system (RESS)"}

\section{Status:}

WIP in Progress

Issued: No Originals

\section{Overview:}

This part of ISO 6469 specifies requirements for the on-board rechargeable energy storage systems (RESS) of electrically propelled road vehicles, including $\mathrm{BEV}, \mathrm{FCV}$, and HEV, for the protection of persons inside and outside of the vehicle and the vehicle environment. Flywheels are not included in the scope of this standard.

It does not apply to RESS in motorcycles and vehicles not primarily intended as road vehicles such as material handling trucks or fork-lifts.

It applies only to RESS in on-board voltage class B (see Clause 3 ) electric circuits for vehicle propulsion.

It does not provide comprehensive safety information for manufacturing, maintenance and repair personnel.

\section{Analysis:}

The new draft standard is owned by the ISO Electric Road Vehicle subcommittee (ISO TC22/SC21). This document is in the publication stage and should be published in October 2009.

Document Location:

Not Applicable at this time 


\section{ISO/FDIS 6469-2:2009(E): "Electrically}

propelled road vehicles - Safety specification - Part 2: Vehicle Operational Safety Means and Protection against Failures"

\section{Status:}

WIP in Progress

Issued: No Originals

\section{Overview:}

This part of ISO 6469 specifies requirements for operational safety means and protection against failures related to hazards specific to electrically propelled road vehicles including BEV, FCV, and $\mathrm{HEV}$, for the protection of persons inside and outside of the vehicle and the vehicle environment.

It does not apply to motorcycles and vehicles not primarily intended as road vehicles such as material handling trucks or fork-lifts.

Requirements related to ICE systems of HEV and not covered in this standard. It applies only if the maximum working voltage of the on-board electrical propulsion system is lower than the upper voltage class B (see Clause 3 ) limit.

It does not provide comprehensive safety information for manufacturing, maintenance and repair personnel.

\section{Analysis:}

The new draft standard is owned by the ISO Electric Road Vehicle subcommittee (ISO TC22/SC21). This document is in the publication stage and should be published in October 2009.

Document Location:

Not Applicable at this time 


\section{ISO/CD 6469-3.3: "Electrically propelled road vehicles - Safety specification - Part 3: Protection of persons against electric shock"}

\section{Status:}

WIP in Progress

Issued: No Originals

\section{Overview:}

This part of ISO 6469 specifies requirements for the electric propulsion systems and conductively connected auxiliary systems, if any, of electrically propelled road vehicles for the protection of persons inside and outside the vehicle against electric shock.

It does not apply to motorcycles and vehicles not primarily intended as road vehicles such as material handling trucks or fork-lifts.

It applies only to on-board electric circuits with maximum working voltages according to voltage class $\mathrm{B}$.

It does not provide comprehensive safety information for manufacturing, maintenance and repair personnel.

Requirements for the electric power supply interface conductively connected to the external power supply (grid) for charging the RESS are also specified in IEC 61851-1 and IEC 61851-21.

\section{Analysis:}

The new draft standard is owned by the ISO Electric Road Vehicle subcommittee (ISO TC22/SC21). The document has been approved for DIS (draft international standard) ballot.

Document Location:

Not Applicable at this time 


\section{ISO/CD 12405-1: "Electrically propelled road vehicles - Test specification for lithium-ion traction battery packs and systems - Part 1 "High power applications"}

\section{Status:}

WIP in Progress

Issued: No Originals

\section{Overview:}

This Standard specifies test procedures for lithium-ion battery packs and systems, to be used in electrically propelled road vehicles.

The specified test procedures shall enable the user of this standard to determine the essential characteristics of performance, reliability and abuse of lithium-ion battery packs and systems. The user shall also be supported to compare the test results achieved for different battery packs and systems.

Therefore the objective of this standard is to specify standard test procedures for the basic characteristics on performance, reliability and abuse of lithium-ion battery packs and systems.

This standard enables setting up a dedicated test plan for an individual battery pack or system subject to an agreement between customer and supplier. If required, the relevant test procedures and/or test conditions of lithium-ion battery packs and systems may be selected from the standard tests provided in this standard to configure a dedicated test plan.

Part 1 specifies the tests for high power battery packs and systems.

\section{Analysis:}

The new draft standard is owned by the ISO Electric Road Vehicle subcommittee (ISO TC22/SC21). This document has closed the committee ballot stage and comments are being reconciled.

Document Location:

Not Applicable at this time 


\section{ISO/WD 23274-2: "Hybrid-electric road vehicles - Exhaust emissions and fuel consumption measurements - Part 2: Externally chargeable vehicles"}

\section{Status:}

WIP in Progress

Issued: No Originals

\section{Overview:}

This part of ISO 23274 specifies a chassis dynamometer test procedure to measure the exhaust emissions and the electric and fuel energy for the vehicles. The vehicles specified in this part are hybrid-electric road vehicles (HEV) with an internal combustion engine (IEC) and the on-board rechargeable energy storage system (RESS) for vehicle propulsion in which electricity is supplied from the external commercial power source at the grid. The vehicles also satisfy the following:

1. not being the RESS charged while driving unless by regenerative breaking and/or by generating by ICE (Trolleybuses and solar powered vehicles are not included in the scope)

2. being classified as passenger cars or light duty trucks, as defined in each regional annex

3. the nominal energy of the RESS is at least $2 \%$ of the total energy consumption over a applicable driving test

4. using only liquid fuels (for example, gasoline and diesel fuel).

\section{Analysis:}

The new draft standard is owned by the ISO Electric Road Vehicle subcommittee (ISO TC22/SC21). This document is a working draft (WD) NWIP (new work item proposal) ballot was approved at the June plenary of TC22/SC21. Balloting will conclude October 7, 2009 and if passed will identify continuing work on the document as official business of the committee.

Document Location:

Not Applicable at this time 


\section{ISO XXX "Terminology Technical Report"}

\section{Status:}

WIP in Progress

Issued: No Originals

\section{Overview:}

This Technical Report (TR) summarizes all terms and definitions (Tad) used and listed in the clause Terms and definitions of the publications developed by ISO/TC 22/SC 21, Electrically propelled road vehicles (EPV). These terms are specific to the electric propulsion systems of such vehicles, i.e., battery electric vehicles (BEV), hybrid electric vehicles (HEV), and (pure and hybrid electric) fuel cell vehicles (FCV).

Tad on other vehicle systems and terms referring to characteristics, which are common with vehicles powered by an internal combustion engine only, are not included.

The Tad are listed in a systematic order (from general to specific) in relation to a specific subject they belong to (e.g., Performance of EPV).

Additionally included are also some terms not used in the SC 21 publications, but closely related to the terms used there in order to better understand the relation of the tad belonging to one subject. Such additional terms do not appear in the other SC 21 publications.

\section{Analysis:}

No number has been assigned yet. The new draft standard is owned by the ISO Electric Road Vehicle subcommittee (ISO TC22/SC21).

Document Location:

Not Applicable at this time 


\section{National Fire Protection Agency (NFPA) NFPA 70 National Electrical Code (NEC) Article 625: Electric Vehicle Charging System Equipment}

\section{Status:}

WIP for NEC January 2011

Issued: NEC January 1996 and 4 pages in length

\section{Overview:}

The National Electrical Code is a standard that all jurisdictions in the United States reference. This article of the National NEC covers the electrical conductors and equipment external to an electric vehicle that connect an electric vehicle to a supply of electricity by conductive or inductive means, and the installation of the equipment and devices related to the electric vehicle charging. The sections of the article are:

Wiring Methods including polarization, non-interchangeablility, construction and installation, unintentional disconnection, grounding pole, and grounding pole requirements.

Equipment Construction including electric vehicle supply equipment, Rating, markings for ventilation, means of coupling, cable, interlock, automatic deenergizing of cable, personnel protection system, disconnecting means, loss of primary source, and interactive systems.

Electric Vehicle Supply Equipment Locations including hazardous locations, indoor sites, and outdoor sites.

\section{Analysis:}

Comments by the Code panels have recently been published showing the changes being thought for the 2011 code changes. These are shown in the following:

1. The words "electric vehicles" and "electric vehicle supply equipment" also refers to the "plug-in hybrid electric vehicle and "plug-in hybrid electric vehicle supply equipment"

2. PHEV is defined.

3. Replace the word charge with power transfer.

4. Rechargeable Energy Storage System is defined.

No substantial changes were made, only clarification and new definitions. 
Document Location:

http://www.nfpa.org/freecodes/free access document.asp?id=7008SB 


\section{National Fire Protection Agency (NFPA) NFPA 70 National Electrical Code (NEC) Article 626: Electrified Truck Parking Spaces}

\section{Status:}

WIP for NEC January 2011

Issued: NEC January 2008 and 5 pages in length

\section{Overview:}

The National Electrical Code is a standard that all jurisdictions in the United States reference. This article of the NEC covers the electrical conductors and equipment external to the truck or transport refrigerated unit that connect trucks or transport refrigerated units to a supply of electricity, and the installation of equipment and devices related to electrical installations within an electrified truck parking space. The sections of the article are:

Electrified Truck Parking Space Electrical Wiring Systems including branch circuits, feeder and service load calculations.

Electrified Truck Parking Space Supply Equipment including wiring methods and materials, overhead gantry or cable management, electrified truck parking space supply connection means, separable power-supply cable assembly, loss of primary power, and interactive systems.

Transport Refrigerated Units including disconnecting means and receptacles, and separable power supply cable assembly.

\section{Analysis:}

Comments by the Code panels have recently been published showing the changes being thought for the 2011 code changes. These are shown in the following:

1. Eliminate the need to specifically specify the ampacity of the branch-circuit.

2. Eliminate the need to use optical fiber cables for cable management.

3. Eliminate the term "for existing vehicles."

No substantial changes were made, only clarification and commonizations. Many changes were attempted to be made but were rejected by committee.

Document Location:

http://www.nfpa.org/freecodes/free access document.asp?id=7008SB 


\section{REPORT DOCUMENTATION PAGE}

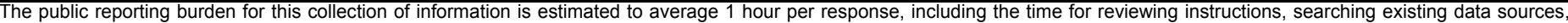

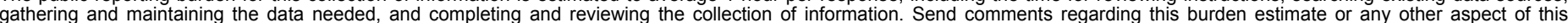

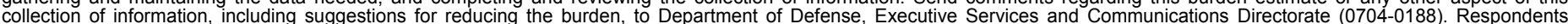

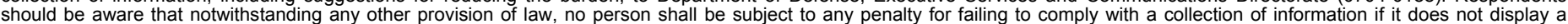

should be aware that notwithstanding

PLEASE DO NOT RETURN YOUR FORM TO THE ABOVE ORGANIZATION.

\begin{tabular}{l|l|l|l} 
1. REPORT DATE $(D D-M M-Y Y Y Y)$ & 2. & REPORT TYPE & 3. DATES COVERED (FrOm - TO)
\end{tabular}

February 2010

Technical Report

4. TITLE AND SUBTITLE

Vehicle Codes and Standards: Overview and Gap Analysis

5a. CONTRACT NUMBER

DE-AC36-08-GO28308

5b. GRANT NUMBER

5c. PROGRAM ELEMENT NUMBER

6. AUTHOR(S)

C. Blake, W. Buttner, and C. Rivkin

5d. PROJECT NUMBER

NREL/TP-560-47336

5e. TASK NUMBER

FC08.7730

5f. WORK UNIT NUMBER

7. PERFORMING ORGANIZATION NAME(S) AND ADDRESS(ES)

National Renewable Energy Laboratory

1617 Cole Blvd. REPORT NUMBER

Golden, CO 80401-3393

NREL/TP-560-47336

9. SPONSORING/MONITORING AGENCY NAME(S) AND ADDRESS(ES)

10. SPONSOR/MONITOR'S ACRONYM(S) NREL

11. SPONSORING/MONITORING AGENCY REPORT NUMBER

12. DISTRIBUTION AVAILABILITY STATEMENT

National Technical Information Service

U.S. Department of Commerce

5285 Port Royal Road

Springfield, VA 22161

13. SUPPLEMENTARY NOTES

14. ABSTRACT (Maximum 200 Words)

This report identifies gaps in vehicle codes and standards and recommends ways to fill the gaps, focusing on six alternative fuels: biodiesel, natural gas, electricity, ethanol, hydrogen, and propane.

15. SUBJECT TERMS

vehicles; codes and standards; gap analysis; alternative fuels; biodiesel; natural gas; electricity; ethanol; hydrogen; propane

\begin{tabular}{|c|c|c|}
\hline $\begin{array}{l}\text { a. REPORT } \\
\text { Unclassified }\end{array}$ & $\begin{array}{l}\text { b. ABSTRACT } \\
\text { Unclassified }\end{array}$ & $\begin{array}{l}\text { c. THIS PAGE } \\
\text { Unclassified }\end{array}$ \\
\hline
\end{tabular}

\begin{tabular}{l|l|} 
17. & LIMITATION \\
OF ABSTRACT & $\begin{array}{l}\text { 18. } \\
\text { NUMBER } \\
\text { OF PAGES } \\
\text { UL }\end{array}$ \\
\end{tabular}

19a. NAME OF RESPONSIBLE PERSON

19b. TELEPHONE NUMBER (Include area code) 